\title{
توجيه القراءات في الجزء السادس عشر من القرآن الكريد
} الباحثة/فاهاهثً بنت إبراهيم بنا عبد المزيز آل عتيقا

\section{معيدة بقسم الدر اسات الإسلامية}

جامعة الأمير سطام بن عبد العزيز - المملكة العربية السعودية الإسله بهابة

التخصص التفسير و علوم القر آن بقسم الكتاب و السنة - كلية الدعوة

و أصول الدين - جامعة أم القرى - المملكة العربية السعودية ولية ولئه

إن الحمد لله نحمده، ونستعينه، ونستغفره، ونعوذ بــالله مــن شــرور أنفـسنا وسيئات أعمالنا، من يهده الله فلا مضل له، ومن يضلل فلا هادي له، و أثثهد أن لا إلـــه

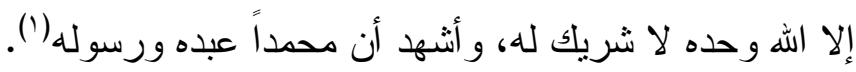

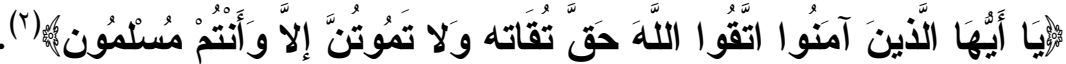

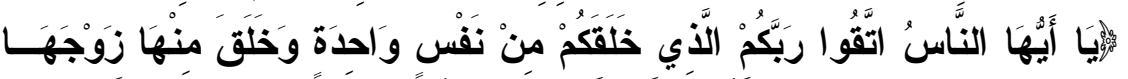

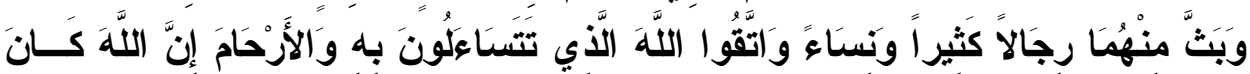

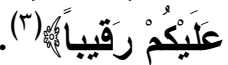

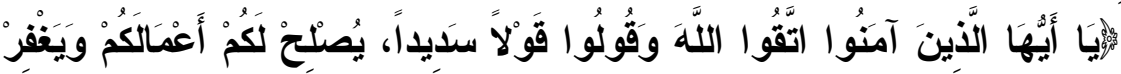

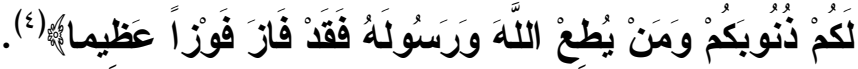
أما بعد:

فإن علم القر اءات من أجل العلم قدراً، و أثشرفها منزلة، وأرفعها مكانة؛ لتعلقــهـ

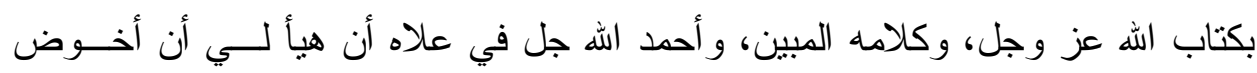

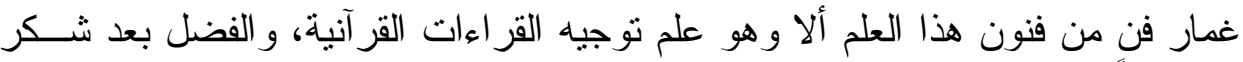

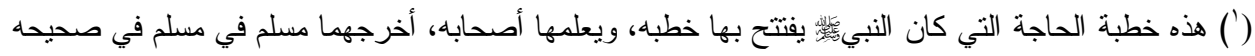

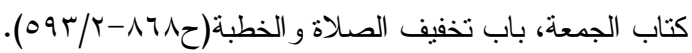

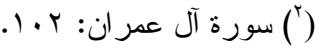

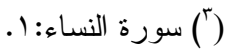

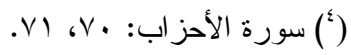


للأستاذ الدكتور محمد محي ولد الثيخ، الذي كلفنا بهذا البحث اليسير على منو ال مـنـهج

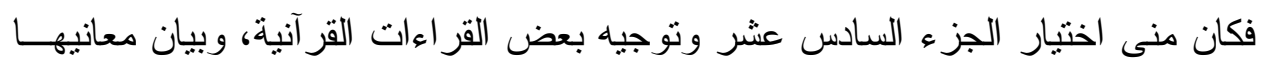

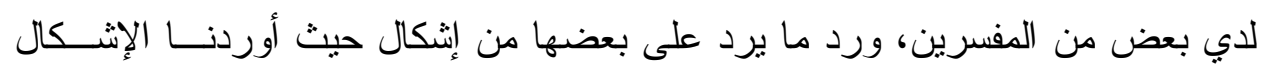

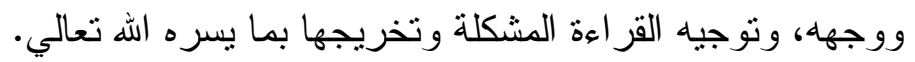

$$
\begin{aligned}
& \text { ثم إني جعلت البحث في مبحثني: } \\
& \text { المبحث الأول: مقدمة في علم توجيه القراءات. }
\end{aligned}
$$$$
\text { و انشتملت على عناوين عدة: }
$$

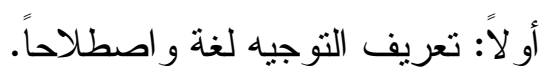

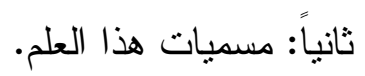

ثالثاً: أهمبة هذا العلم وفائدته.

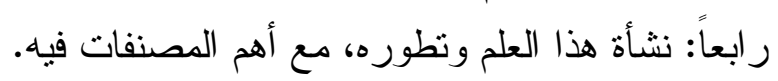

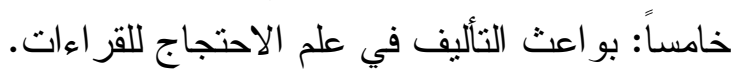

سادساً: علاقة هذا العلم بالنحو.

سابعاً: مفهوم الاختيار ... و أسبابه (').

المبحث الثاني: نوجيهات القر اءعتات القرات آنية.

ور اعيت في ذلك أمرين:

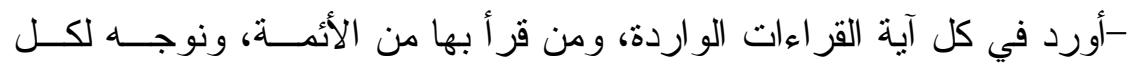

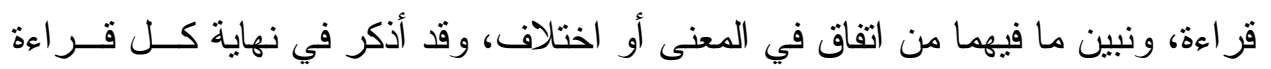

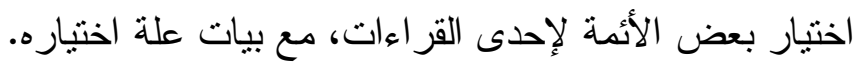

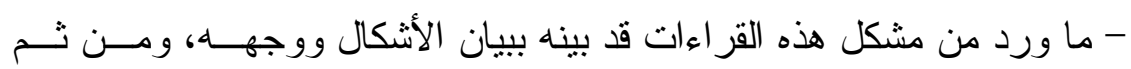
توجيه القراءة الوارد عليها الأشكال مع الرد عليه.

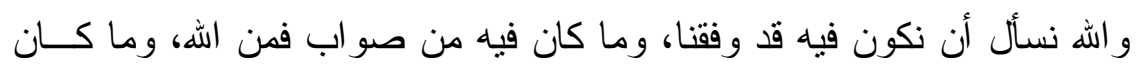
فيه خطأ فاستغفر الله العظيم، رجاءً في مغفرته ولطفه و الحمد لله رب رب العالمين. 
المبحث الأول: مقدمة في توجيه القراعات:

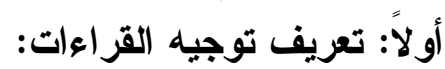

التوجيه في اللغة: من (وجه) و الواو و الجيم و الهاء أصل و واحد يدل على مقابلة

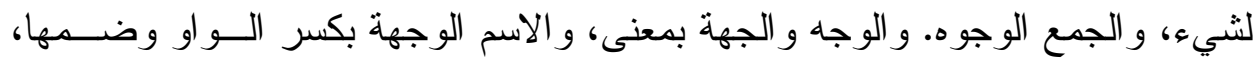
و المو اجهة المقابلة.

و الوجه مستقبل لكل شيء، يقال: وجه الرجل وغيره، وربما عبر عـن الــذات بالوجه.

ويقال هذا وجه الر أي أي: هو الرأي نفسه، وقعد تجاهه بضم التــاء وكـسر ها

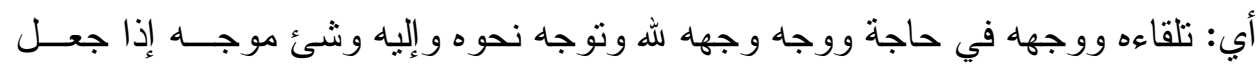

على جهة و احدة لا تختلف (')

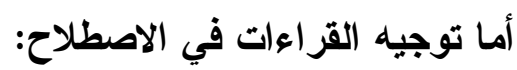

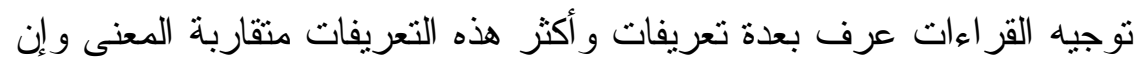

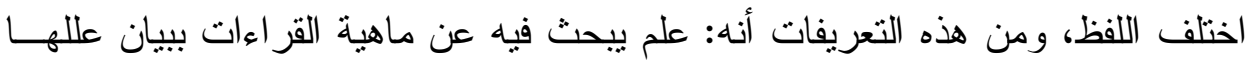

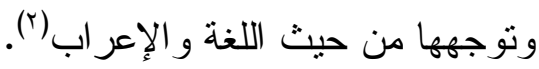

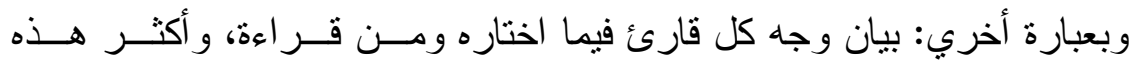

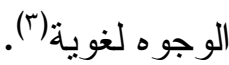
ثانياً: مسميات هذا العلم: لغوية يعرف هذا العلم بعدة تسميات ولعل من أبرزها:

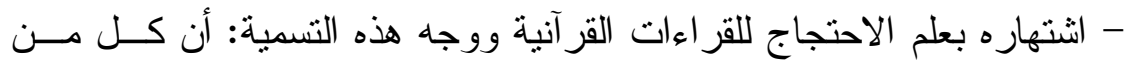

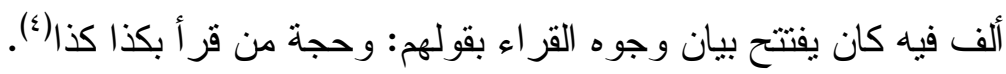
كما عرف بمسميات أخري مثل:

- علم علل القر اءات: وهو علم بتعلق بدر اية القر اءات؛ ويعنى ذلك: أنه لـــــاذا

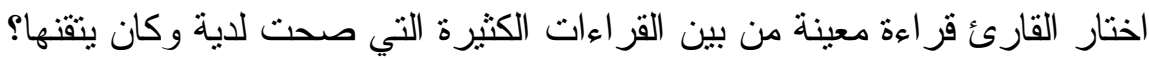

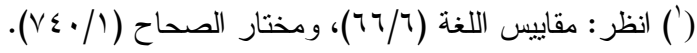

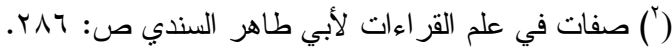

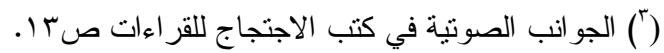

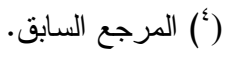




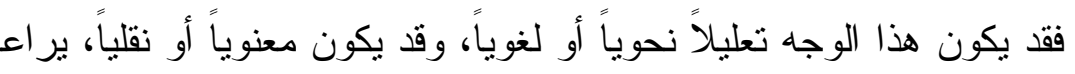

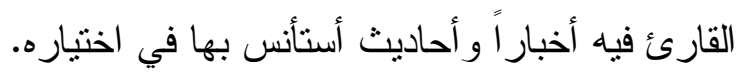

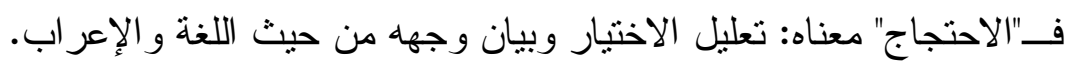

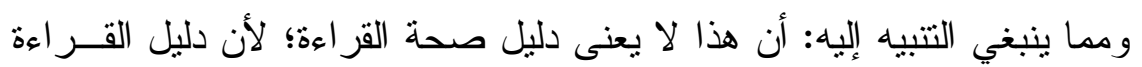

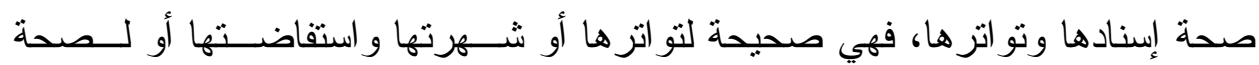

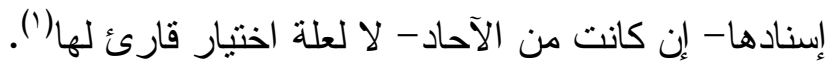
ويسمى كذلك:

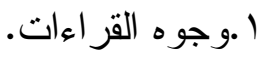

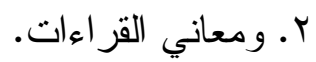

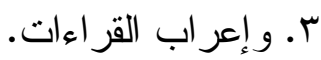

ثالثاً: أهمية علم توجيه القراعات، وغايته:

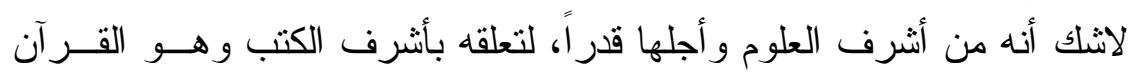

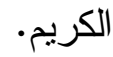
قال الزركثي- رحمة الله(؟): النوع الثالث و العثرون: معرفة توجيه القراءات وتبيين وجه ما ذهب إليه كل قارئ، وهو فن جليل وبه تعرف جلالة المعاني وجز التها،

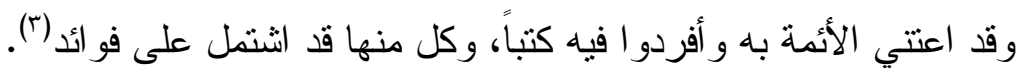

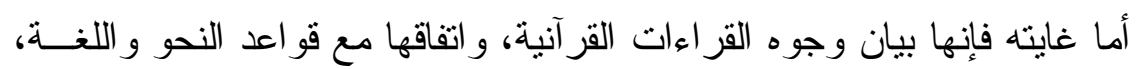

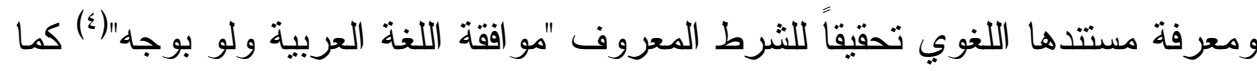

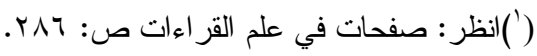

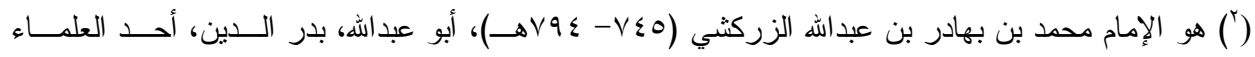

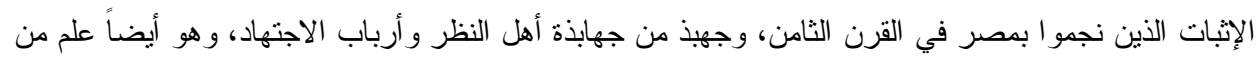

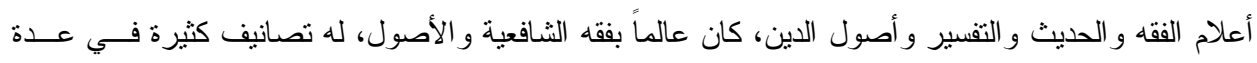

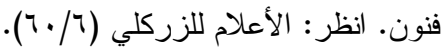

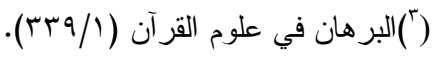

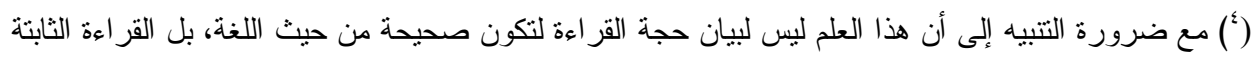

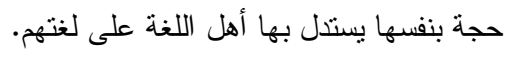


يهدف علم التوجيه إلى رد الاعتر اضات و الانتقــادات التــي يوردهــــا بعـض النحــاة

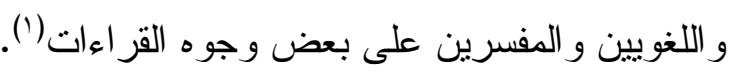

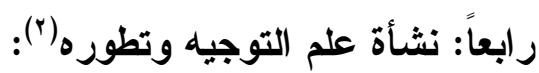
- الاحتجاج في بداية نشأته:

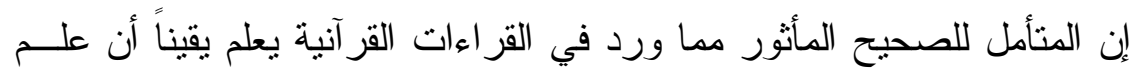

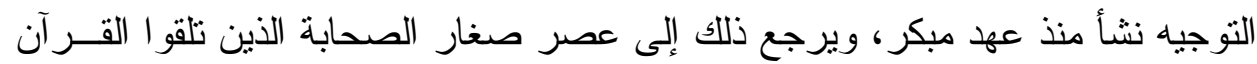
الكريم من كبار هم، وتعرفو ا على القر اءات المختلفة و الوجوه المتعددة للقر اعة.

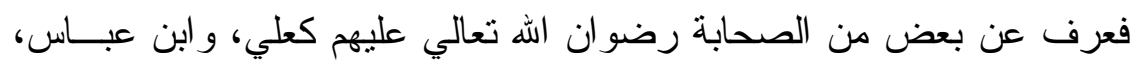

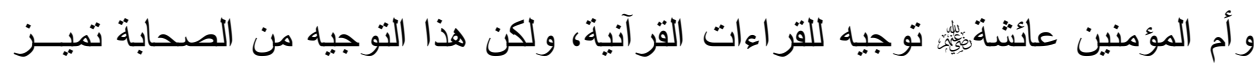
بأمرين:

-أنه ورد عن عدد قليل من الصحابة.

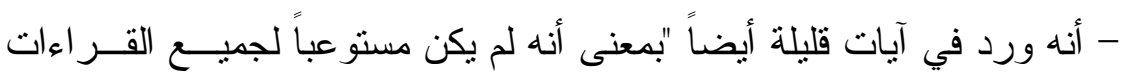
القر آنية"؛ ويعزي السبب في ذلك لأحد أمرين: - أنهم كانوا يوجهون من القراءات القرآنية القر اعة التي يختار ها كل فرد منهم فقط دون غبر ها. - أو أنهم كانو ا يوجهون من القراءات ما كان فيهــا غموضــاً أو نحــوه دون

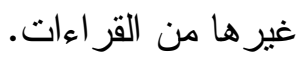
ومن أمنتلة ما يدل على ذلك مما ورد من توجيهات للصحابة:

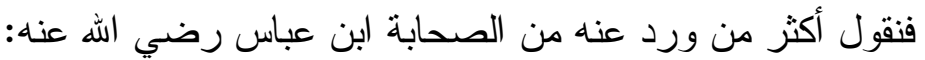

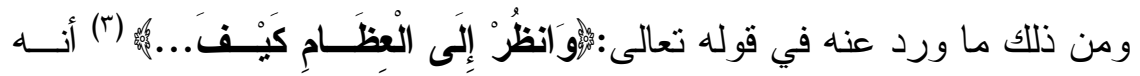

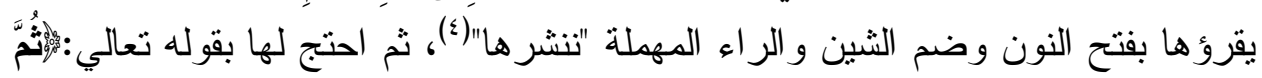

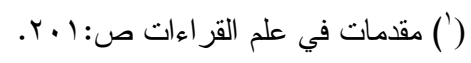
(') تلخيص من: صفحات في علوم القر اءات، ونوجيه مشكل القر اءات العشر. (") سورة البقرة. (أ)سورة عبس. 


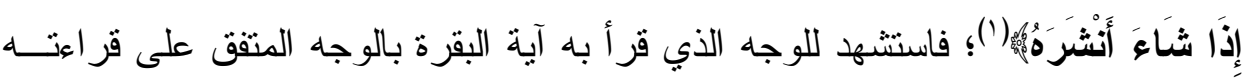
بالر اء في سورة عبس.

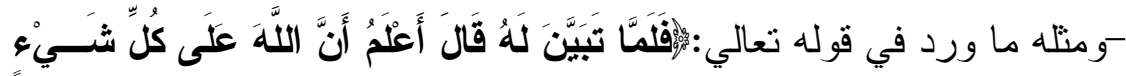

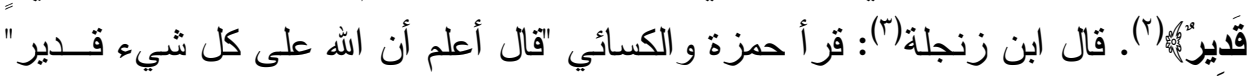

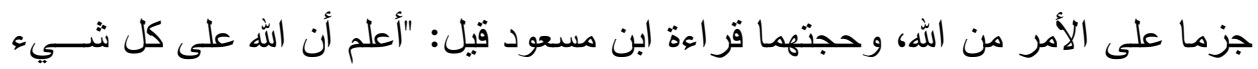

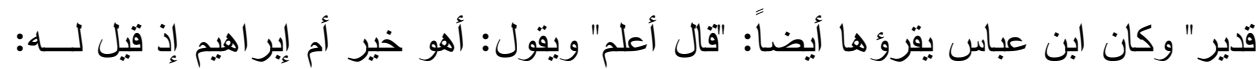

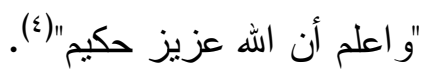
- الاحتجاج في عصر الأئمة القزاء أله

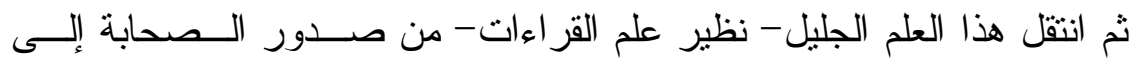

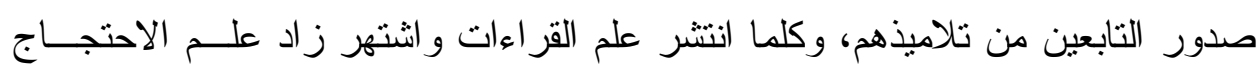
وازدهر

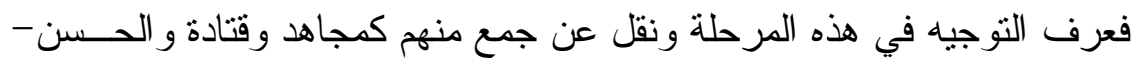

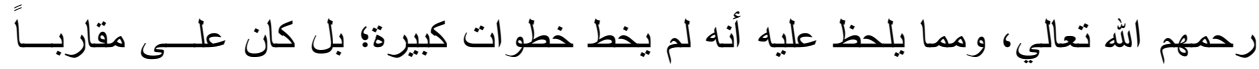
للحال الذي كان عليه في عهد الصحابة رضي الله عنهم.

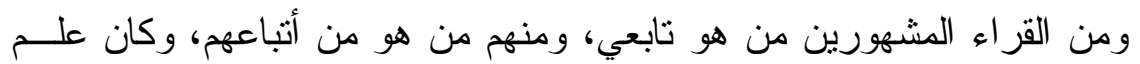

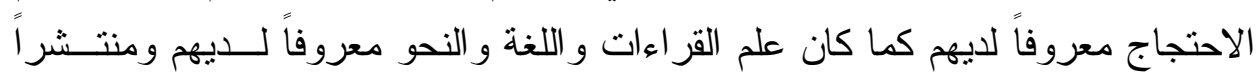
ومن أئمة القر اءات من هو من أعلام اللغة و النحو؛ أمثال: أبــي عمـرو بـن

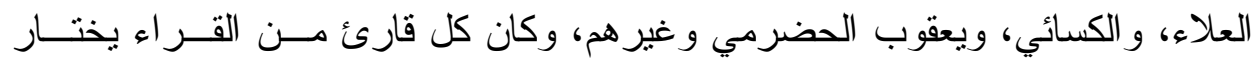

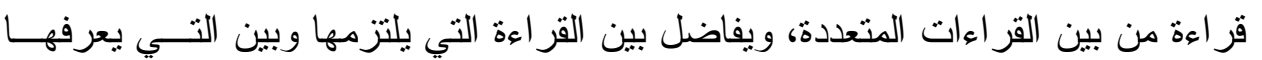
ويتعلمها.

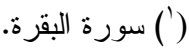

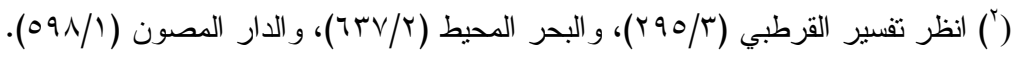

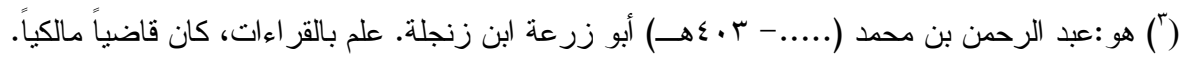

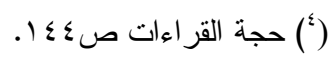


وكانت وجوه المفاضلة متعددة لدي الناس؛ من حيث وفــرة التــواتز وعدمـــه،

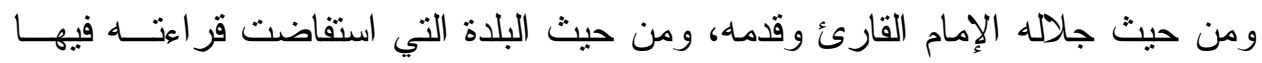

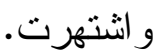

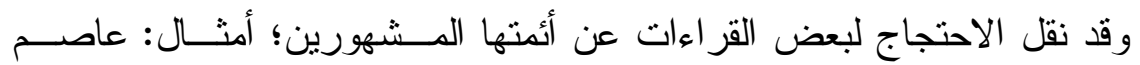

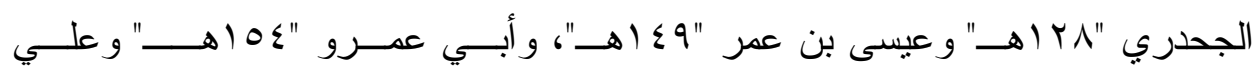
الكسائي "199 اهــ" و وغير هم.

ويعتبر ذلك تخريجات واحتجاجات فردية لبعض القر اءات، ينهج فيها أصحابها

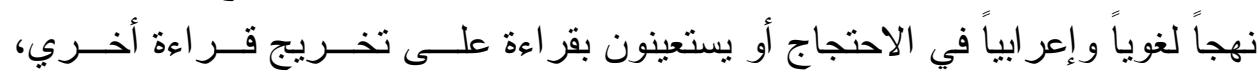
و استمر الأمر على ذلك إلى عصر التذوين والتأليف في الاحتجاج. - الاحتجاج في عصر التدوين والتأليف فيه: ويمكننا أن نقسم هذه المرحلة إلى قسمين باعنبارين:

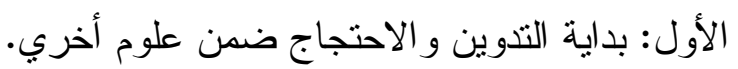
الثاني: مرحلة التدوين و الاحتجاج استقلالاًاً '). ثم نتحدث عن القسم الأول من هذه المرحلة فنقول:

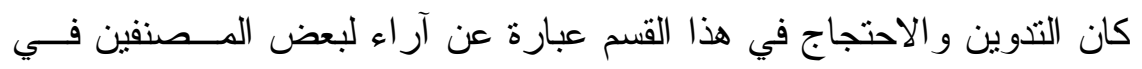

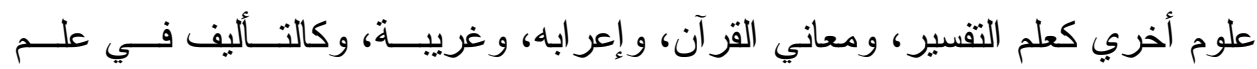

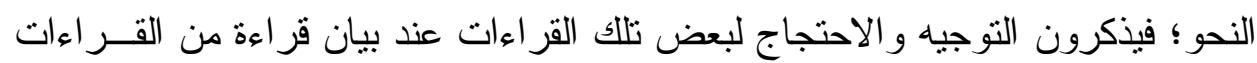
القر آنية.

ومن أو ائل الكتب المؤلفة الر ائدة في هذا القسم كتاب سيبويه(؟). ومن أمنلة ما ذكر في كتابه:

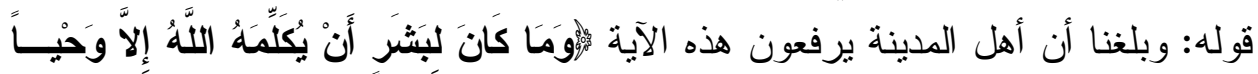

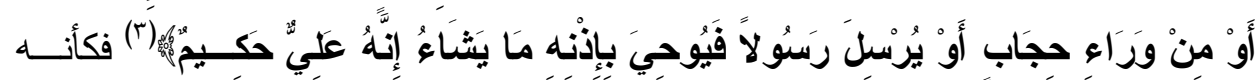

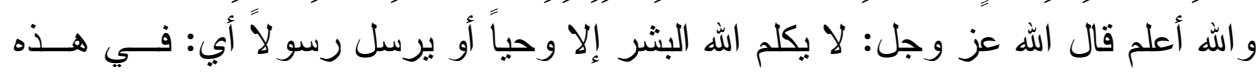

(') (') أي كعلم مستقل بذاته في التصنيف في توجيه القر اءات القر آنية.

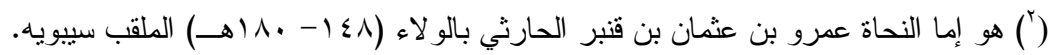

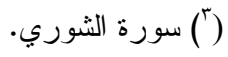


الحال، و هذا كلامه إياهم، كما تقول العرب: و عتابك الـــيف، وكلامـــك القتـل، قــال الثاعر :
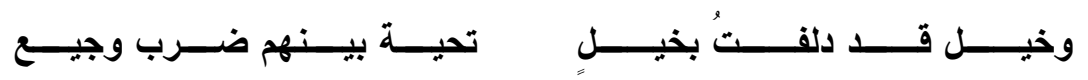

ثم يأتي بعد كتاب سيبويه كتب كثيرة صنفت في معساني القــر آن و إعر ابــهـ وغريبه وتفسيره ومن أمثلتها:

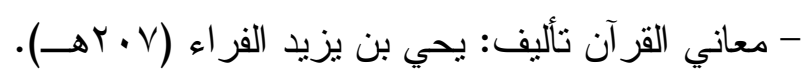

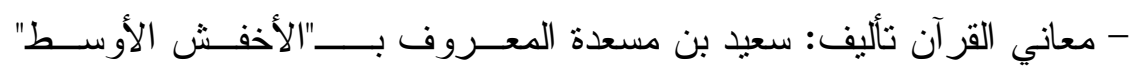

$$
\cdot\left(\rightarrow T^{\prime} 0\right)
$$

- جامع البيان "تفير الطبري" محمد بن جرير (• (اسهـ).

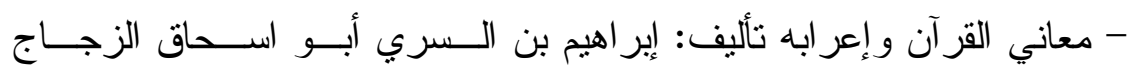

ثم نتحدث عن القسم الثاني من هذه المرحلة وهو يمثــل التــدوين للاحتجــــاج

تدويناً ينفصل عن القسم الأول، وهي كر القراءات ونوجيهها في كتب مستقلة.

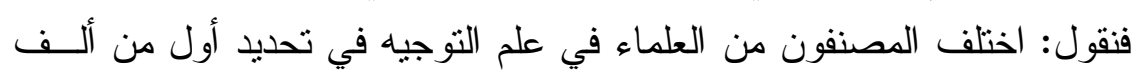

$$
\text { في هذا العلم على أسماء عدة: }
$$

- فيري الدكتور/محمد سالم محيسن أن أول من ألف في الاحتجاج هو أبو بكر

$$
\text { محمد بن السراج (T آسهـ). }
$$

- ويري الدكتور/عبدالفتاح شلبي أن التدوين في الاحتجاج بدأ في القرن الثاني

الهجري.

ونحن في هذا نذكر عبر القرون بعضاً من أثنهر المؤلفات للاحتجاج للقر اءات

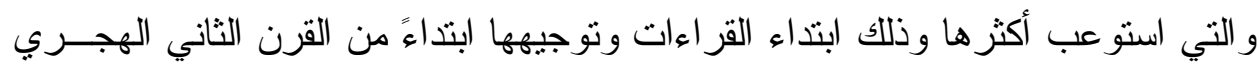
حتى ينتهي بنا المطاف إلى التأليف للاحتجاج في عصرنا الحاضر وذللك حسب الترتيب

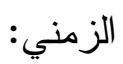
ا.وجوه القراءات لهارون بن موسي الأعور • VIاهـ الذي قال عنه أبو حساتم

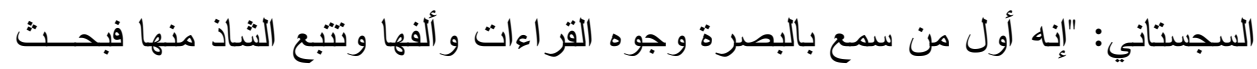
عن إسناده" و البحث عن الإسناد ضرب آنس من الاحتجاج. 


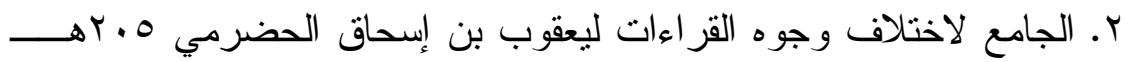

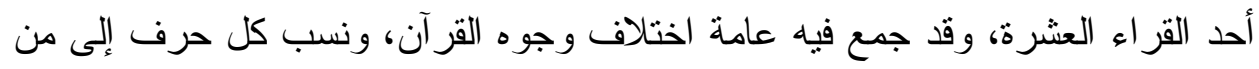

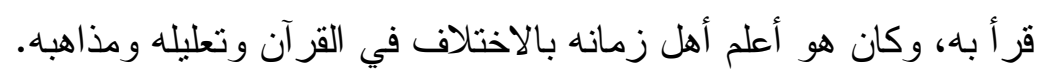

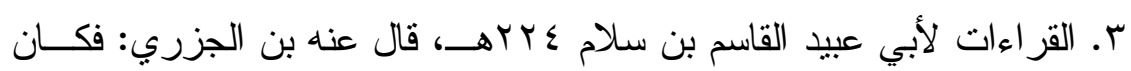
أول إمام معتبر جمع القراءات في كتاب أبو عبيد القاسم بن سلام، جمع فيه.

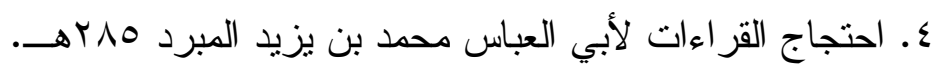

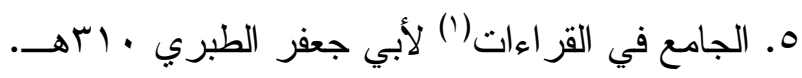

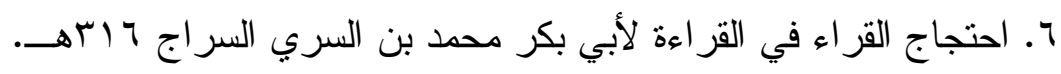

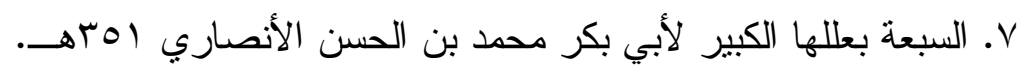

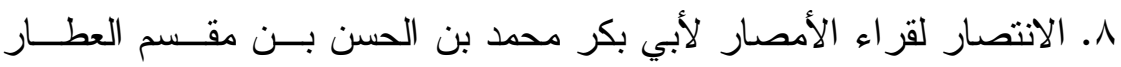
00 مسهـ، ألفه بعد وفاة ابن مجاهد.

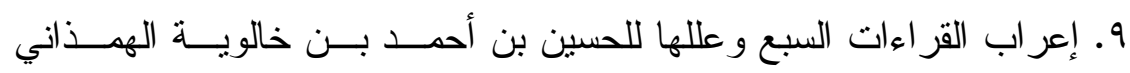
$\rightarrow r V$. • ا ـ الحجة في القر اءات السبع له كذلك.

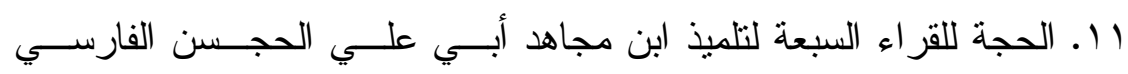
rVV

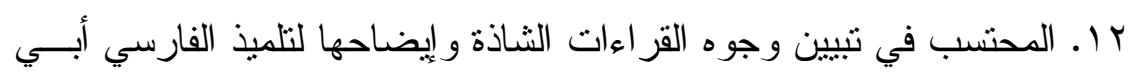

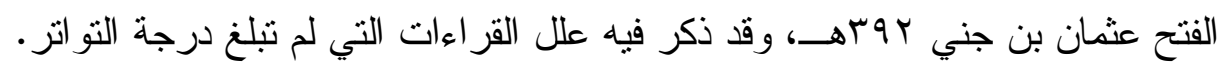

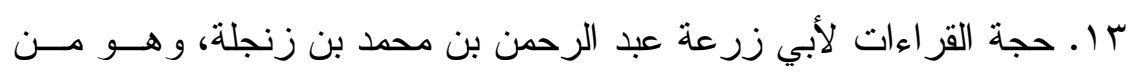

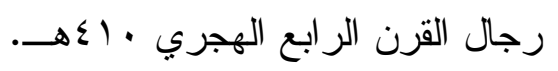

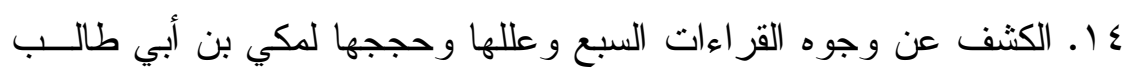

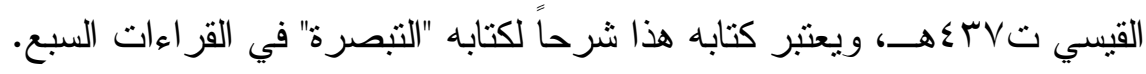

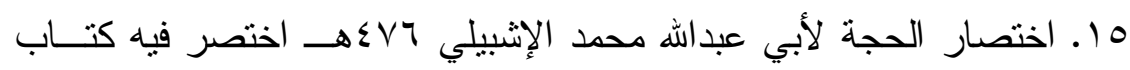
أبي علي الفارسي.

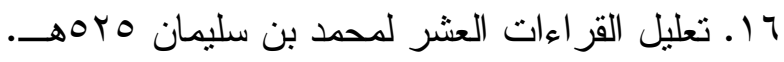


V ا ـ تعليل القراءات الثاذة و المنتخب لأبي البقاء العكبري 7 (آهــ.

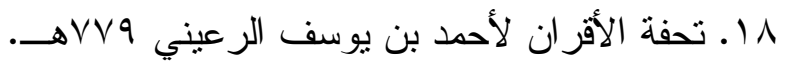
أما كتب المتأخرين في الاحتجاج، فمن أثنهر ها:

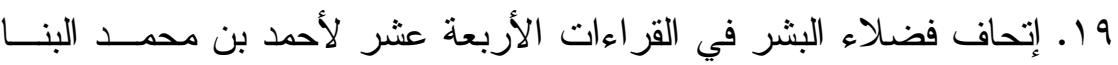
الدمياطي $11 \mathrm{~V}$

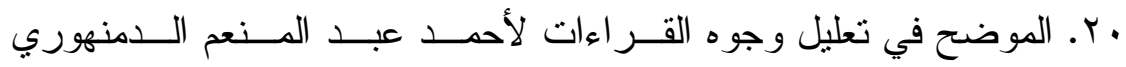

ا Y. القر اءات الثاذة وتوجيهها من لغة العرب للثيخ عبد الفتاح القاضــي ت

$\rightarrow$.

r r. ط طلائع البشر في توجيه القر اءات العشر للشيخ محمد الـصـادق قدحسـاوي

بr. التذكرة في القر اءات الثنلاث المتواترة وتوجيهـا للــدكتور محمــد ســالم محيسن.

ع r. القر اءات و أثزها في التفسير و الأحكام لمحد عمر بازمول.

هr. توجيه مشكل القراءات العشرية القرشية للاكتور عبد العزيز الحربي. خامساً: بو اعث التأليف في علم الاحتجاج للقر اءات (')

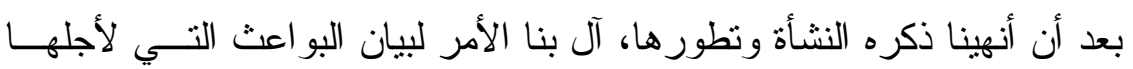

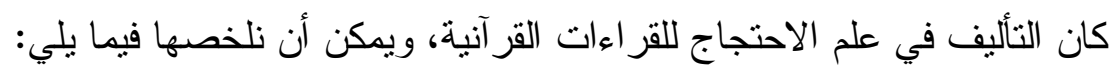

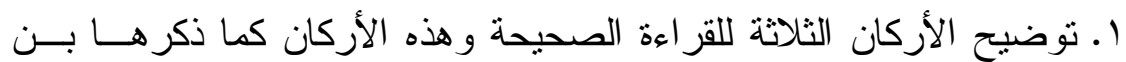

$$
\begin{aligned}
& \text { الجزري رحمه الله(؟) وهي: الإكئ } \\
& \text { - صحة السند. } \\
& \text { - مو افقة أحد المصاحف العثمانية ولو احتمالاً. } \\
& \text { - مو اققة العربية ولو بوجه. }
\end{aligned}
$$

(') انظر ذلك عدة مر اجع منها: توجيه مشكل القر اءات للاكتور /عبدالعزيز الحربي، وصفحات في علوم القر اءات د/عبد القيوم السندي، و الجو انب الصوتية في كتب الاحتجاج للقراءات دم/عبد البديع النيرباني.

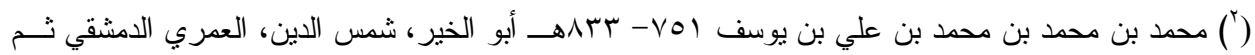


وقد جمعها في طيبة النشر بقوله:

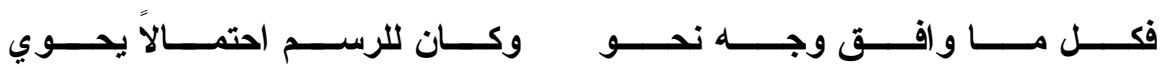

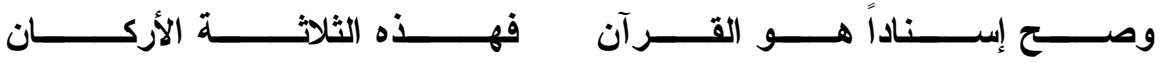

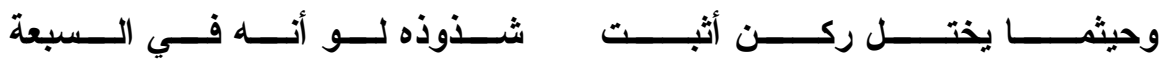

r. الدفاع عن القر اءات لاسيما المنو اترة ضد من توهم أن فيها لحناًً').

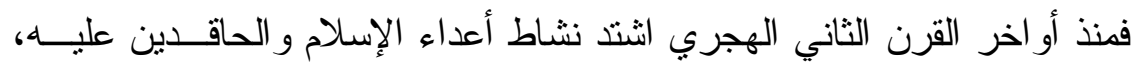
وقد أخذ هذا النشاط ينمو حتى قوى واستحصد في القرن الثالث الهجري، وما تلاه مـن

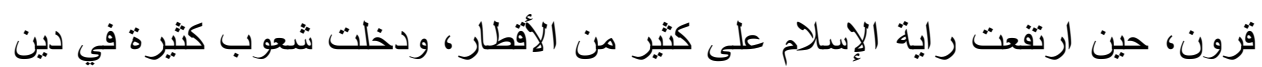

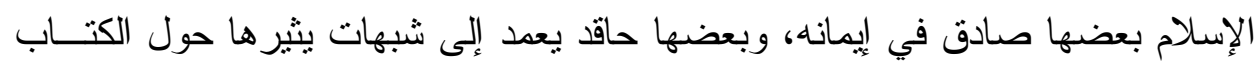

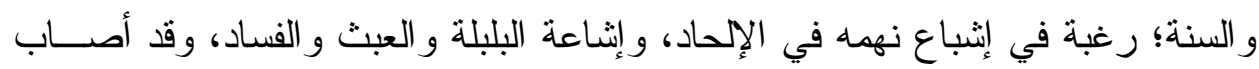

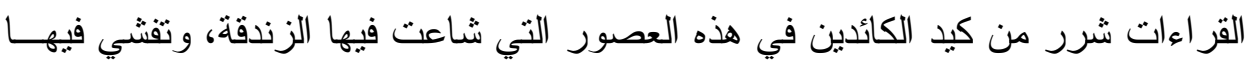
الإلحاد؛ حيث يثيرون منل هذه الأسئلة:

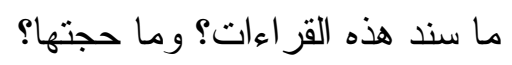

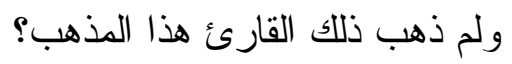

و هل له معتمد من اللغة و النحو

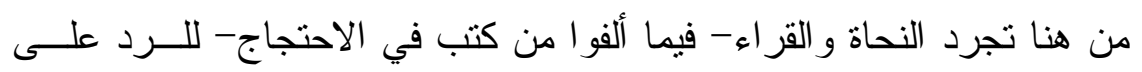

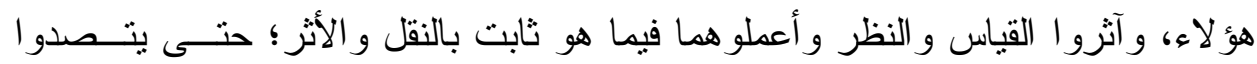

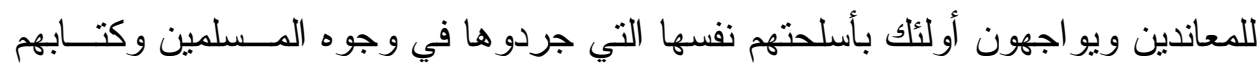

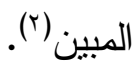

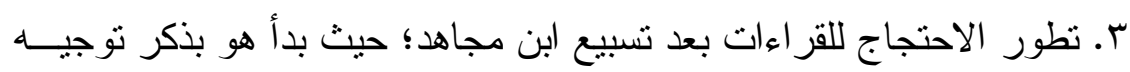

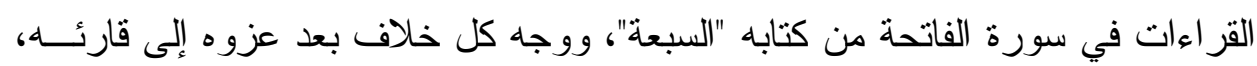


إلا أنه أمسك عن ذلك بعد انتهائه من الكلام في خلافات سورة الفاتحة مخافة التطويـلـ

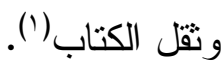

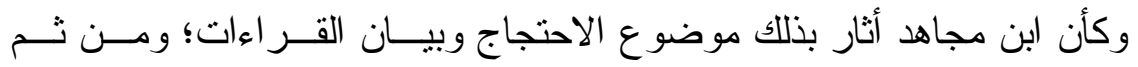

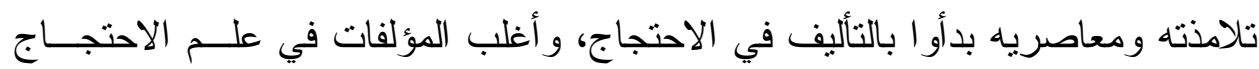

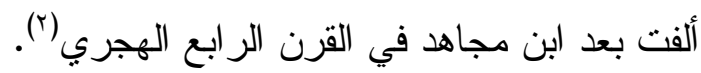

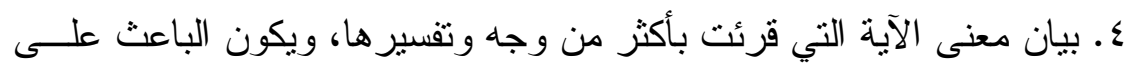

ذلك هو التوضيح و الإفهام لوجع تقسيرية متعددة.

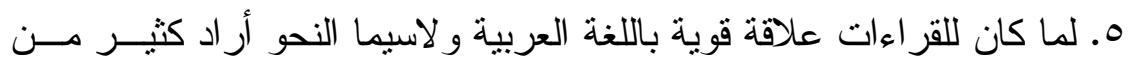

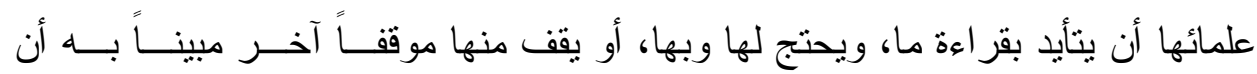

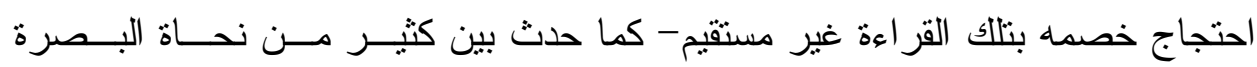
و الكوفة.

7. وقد يكون من الأسباب أن "الكتاب"لسيبويه اثنتمل على توجيهات قــر اءات

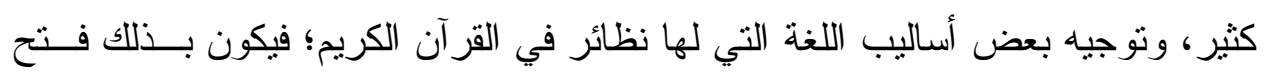

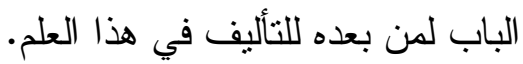

و هذه البو اعث هي أكثر ما ذكر في المصنفات لهذه العلم، غير أن الدكتور عبد

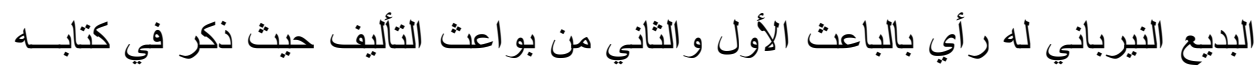

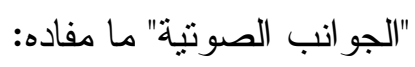

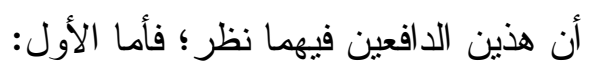

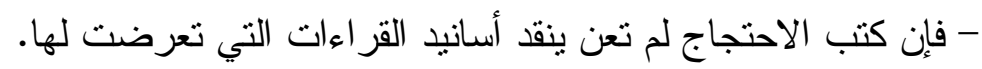

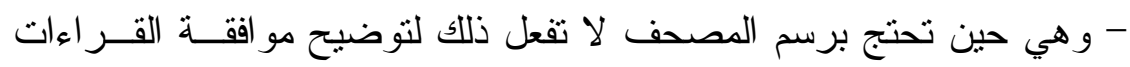

لمرسوم الخط؛ و إنما لترجح قر اءة على أخرى.

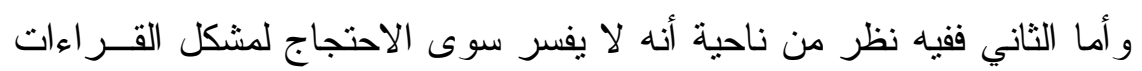

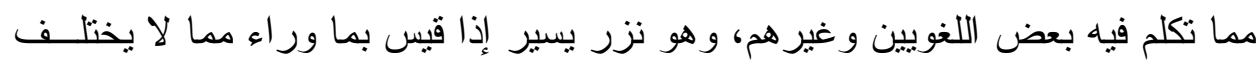
على صحته لفظاً ومعنى.

(') قال أبو بكر بن مجاهد في ذلك: اسنطلت ذكر العلل بعد هذه السورة وكرهت أن يثقل الكتاب فأمسكت عـن

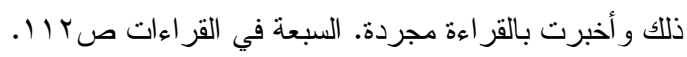

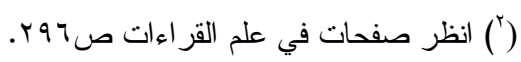




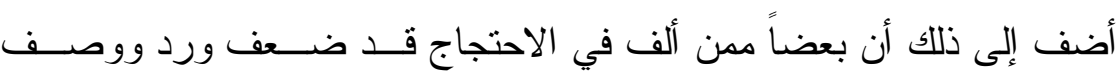
بالو هم و اللحن بعض القر اءات المتو اترة.

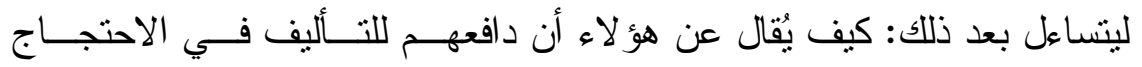
للقر اءات هو الدفاع عنها؟! ثم ر أي بعد ذلك أن الدافع للتأليف أن كتب القر اءات لما كانت كتــب "روايــة"

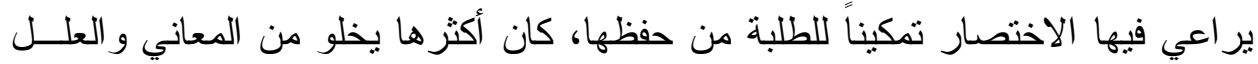
فجاءت كتب الاحتجاج وهي كتب "در اية" تشر ح ما اختصر فيها.

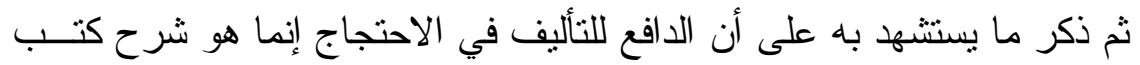

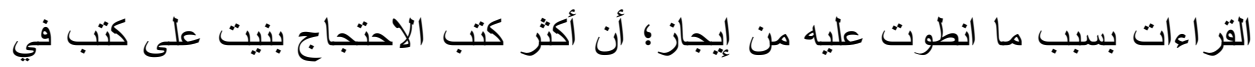

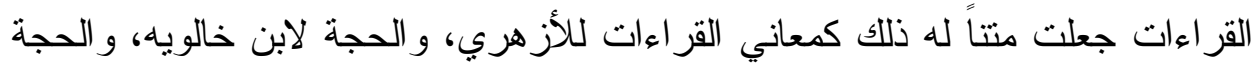

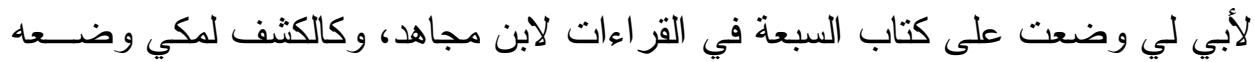
على التبصر ه له، و غير هم ممن ذكر.

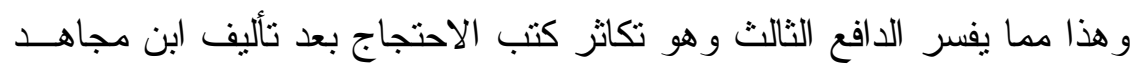
كتابه السبعة. وقد جاء في مقدمة تحقيق "الهحتسب" لبن جنى قولهم: وبعد، فكأنما كان تأليف

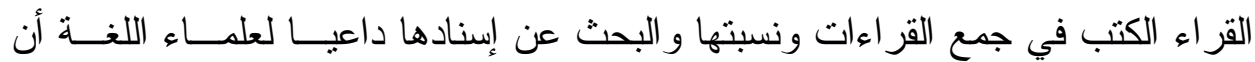

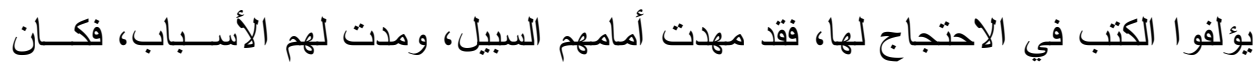
جمع القر اءات الخطوة الأولى والاحتجاج لها الخطوة النالية، والله أعلم (').

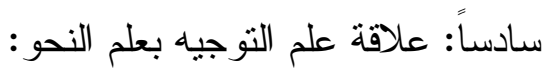
هناك علاقة وطيدة ومتينة بين توجيه القراءات و النحو ؛ و لا غني لعلم القراءات عن نحو يوجه تللك القراءات ويوضح سبيلها في العربية، كما قيل:

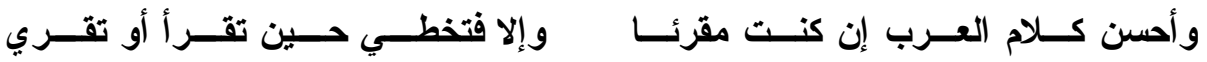

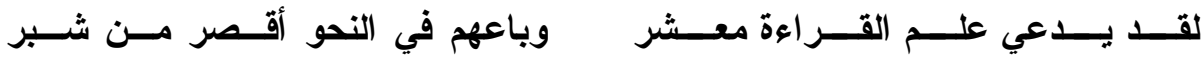


فــإن قيـلـل مـــا إعــراب هـــا ووزنــه رأيت طويل الباع يقصر عـن فتـر (') وجاء في الأرجوزة المنبهة في صفة من لا يؤخذ عنهم العلم:

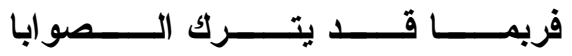

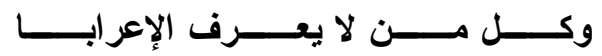
$(r) d$

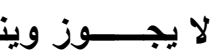

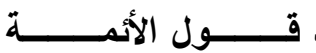
وربمــــــــــ سابعاً: الاختيار مفهومه و أسبابه: ولما رأيت في توجيه بعض القراءات عند علماءه، أو عند المفسرين قولهم: "و الاختيار"، رأيت أن أعرف بمفهوم "الاختيار" لدي القر اء على إيجاز :

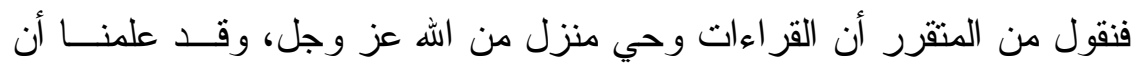

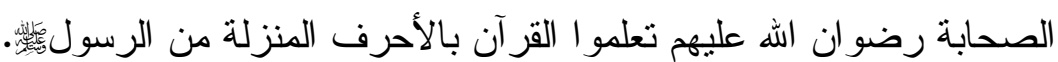

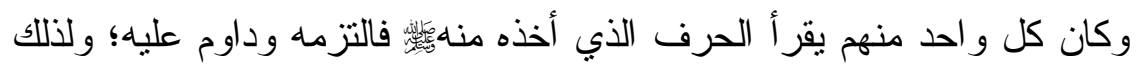
نسبت بعض الأحرف إلى بعض الصحابة، فيقال حرف أبي، وحرف ابن مسعود.

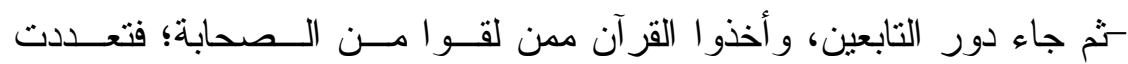
الأحرف لديهم. - ثم جاء دور تلامذتهم، وقد توسعوا في أخذ الأحرف وتلقيها من أســاتذتهم مــن

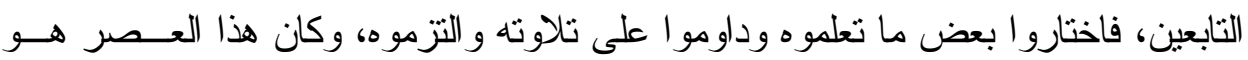

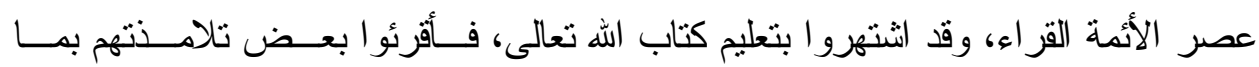

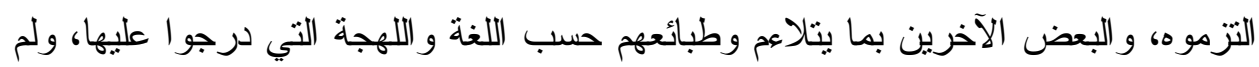

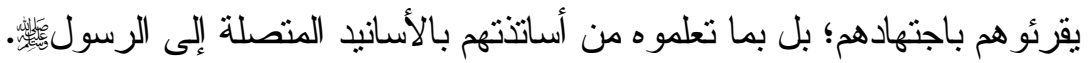

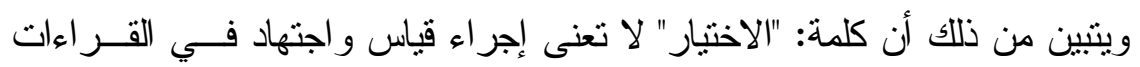

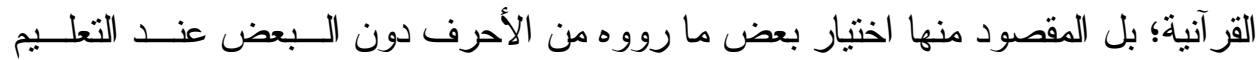

$$
\begin{aligned}
& \text { و الإقر اء. } \\
& \text { و أما عن أسباب الاختيار : } \\
& \text { فإن لذلك سببان: }
\end{aligned}
$$

(') مظاهر التجديد في التوجيه النحوى للقر اءات القر آنية د/مبروك حمود الثايع بحث في مجلة كلية اللغة العربية جامعة الأزهر. (') الأرجوزة المنبهة لأبي عمرو (1/1) (1). 
ا .الترجيح بين الروايات، و اختيار أثنهر ها و أكثر ها رو اة؛ لأنهم كانو ا ينتبعـون

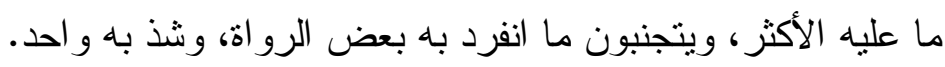

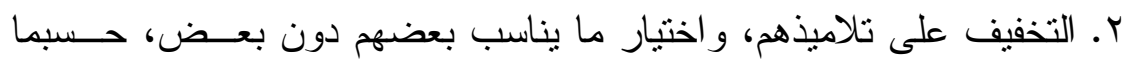

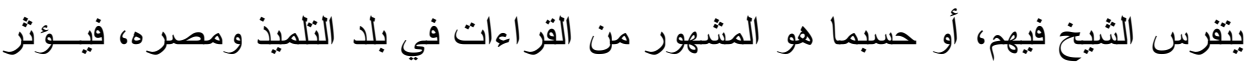

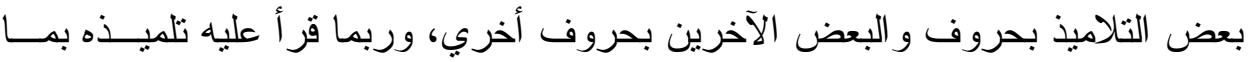

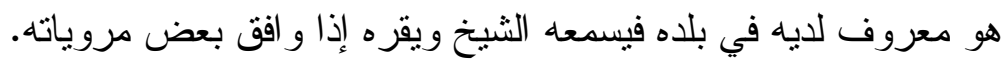

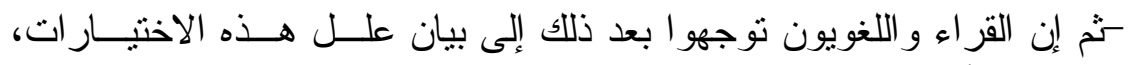

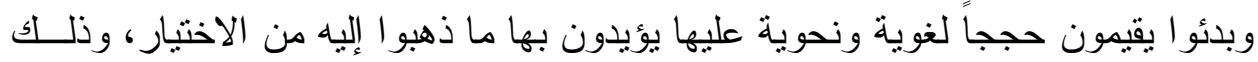

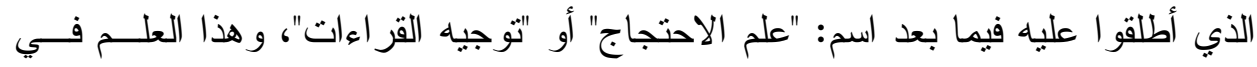

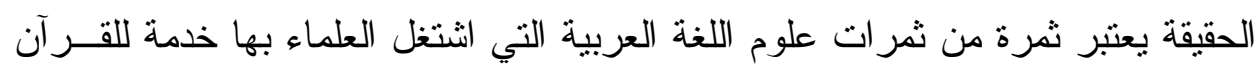
الكريم.

وكان "الاحتجاج" بالقر اءات لدى القدامي لإثبات قو اعد النحو وعلم اللغة؛ ولكن لدي قلة من اللغويين وبقدر محدود.

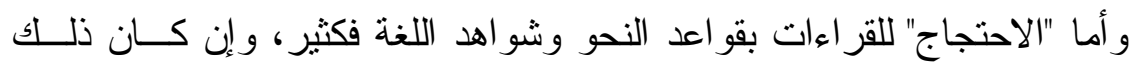

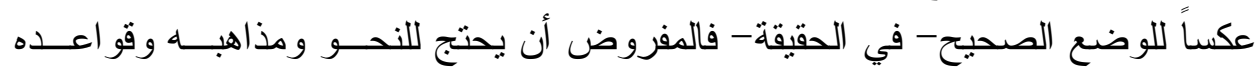

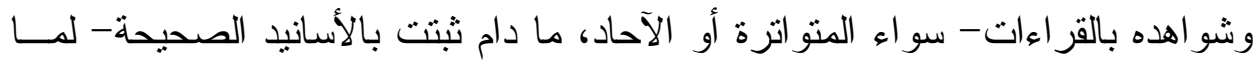

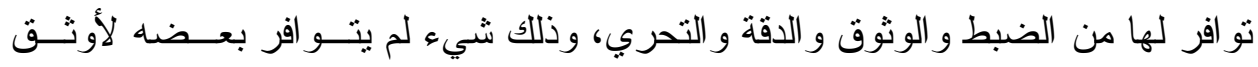
شو اهد النحو. تون

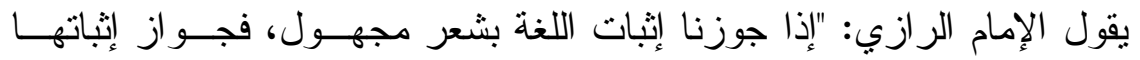

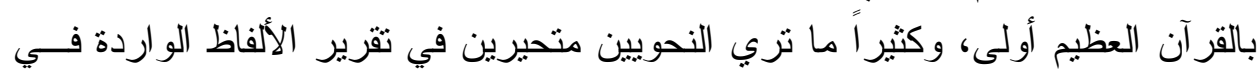

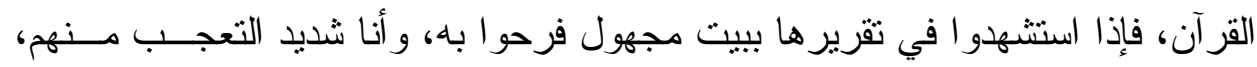
فإنهم إذا جعلو اورود ذلك البيت المجهول على وفقها دليلاً على صحتها كان أولى.

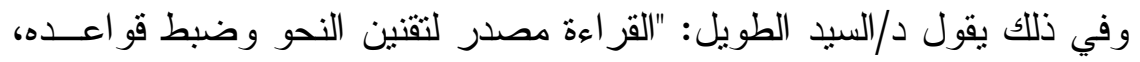

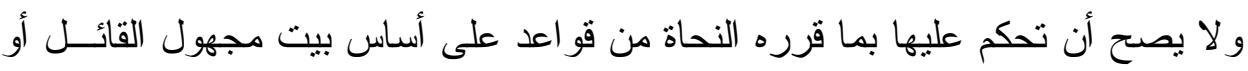
عبارة قالها عربي في البادية. ثم إنه ليس الغرض تصحيح القر اعة بقو اعد العربية؛ بل تصحيح قو اعد العربية بالقر اءة) (') - (1) 
المبحث الثاني: توجيهات في الآيات القرآنية:

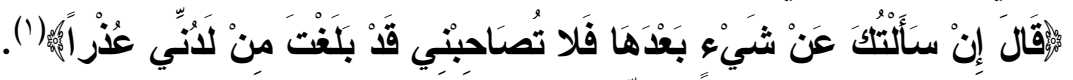

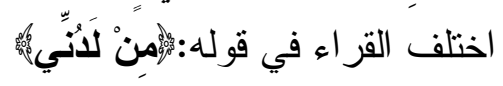

- فقر أ أبو بكر عن عاصم بفتح اللام و إثمام الدال ضمة مختلسة مع تخفيــف لفئ النون.

- وقر أ نافع بضم الدال مع تخفيف النون. - وقر أ الباقون بضم الدال وتشديد النون.

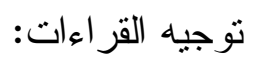
أصل هذه الكلمة "لدن" بإسكان النون، فإذا أضفتها إلى نفسك زدت نوناً ليـسلم

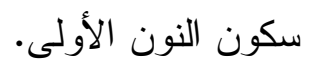
تقول: "لان زيد" فتسكن النون، ثم تضيف إلى نفسك فتقول: "لاني" فتدغم النون في النون كما تقول: "عنى" (؟).

-أما من خفف النون: فإنه كره اجتماع النون فحذف واحدة، وهي وهي الثانية لأنهــا زائدة كما حذف من قوله: "تأمروني"، وكما حذفت من قدني وقدي في قول الثاعر :

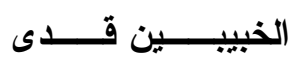
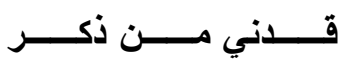

ـو أما إثنمام الدال فإنه علامة على أن الدال كانت مضمومة(").

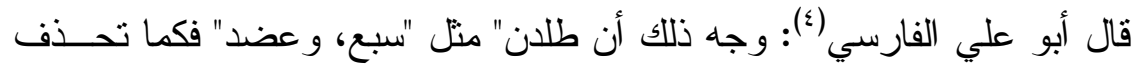

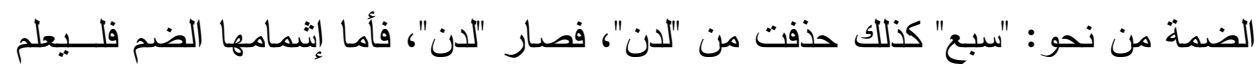

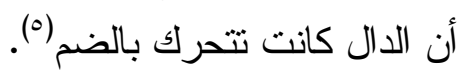

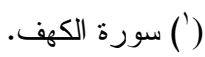

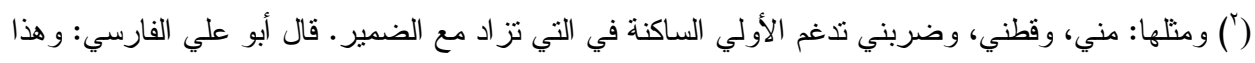

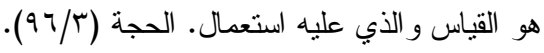

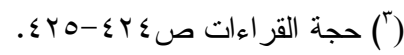

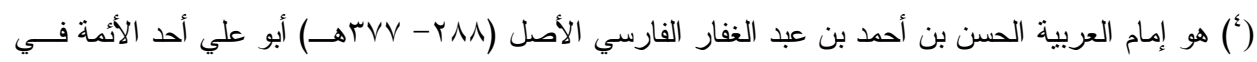

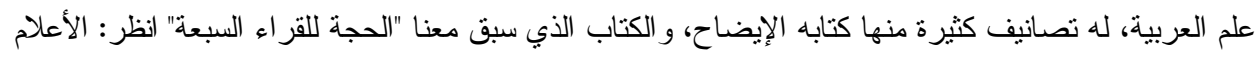

$$
\begin{aligned}
& \text { للزركلي (r/ (1) ). } \\
& \text { ( ) معاني القر اءات (T/Y (1) (1) ). }
\end{aligned}
$$


هذا وقد اختار أبو منصور الأزهري(')، و الطبري(؟) قر اءة: فتح الــلام وضـــ

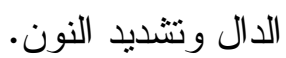

قال أبو منصور الأزهري: هي لغات معروفة، وأجودها في القر اءة فتح الــلام

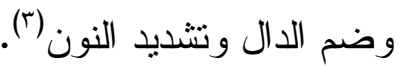

وقال الطبري في قر اهة التخفيف و التشديد: و الصواب من القول في ذللك عندي

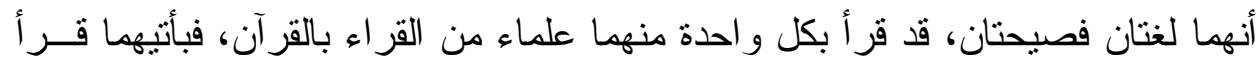

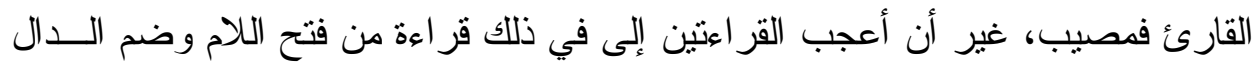
وشدد النون، لعلتين: - أحداهما: أنها أثنهر اللغتين.

- و الأخري: أن محمد بن نافع البصري حدثنا، قال: ثنا أمية بن خالد، قال: ثنا

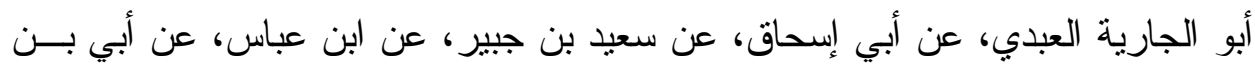

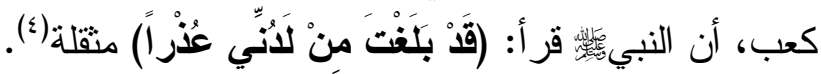

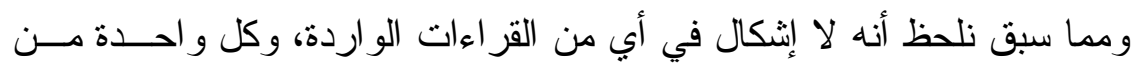

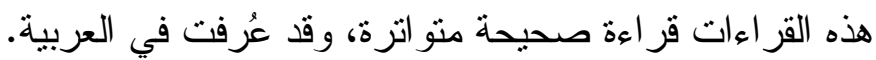

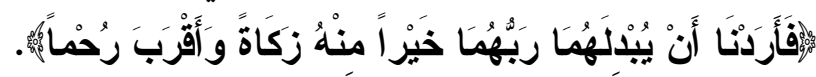
اختلفت القر اء في قوله: "يبدلهما". - فقر أ نافع و أبو عمرو بالتشديد "يبدلهما" في جميع القرآن. - وقر أ الباقون بالتخفيف.

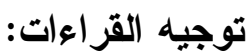
نقول هما لغتان يقال: "بدل و أبدل" منل : "نزل و أنزل".

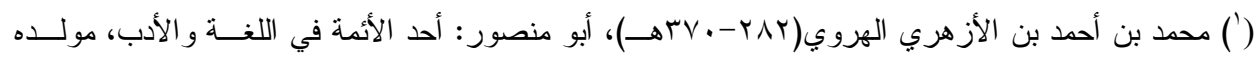
ووفاته في هر اة بخر اسان.

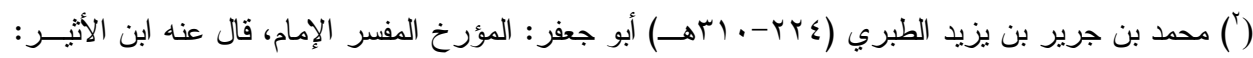
أبو جعفر أوثق من نقل التاريخ.

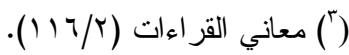

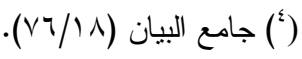


قال ابن زنجلة: وحجة التشديد: قوله: "و إذا بدلنا آيه" وقال: "لا تبديل لكلمـات

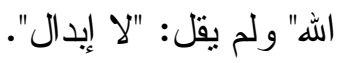

وحجة التخفيف: قوله: "و إن أردنم استبدال زوج" فهذا قد يكون بمعنى الإبــدال كما أن قوله... - n

فلم يستجبه عند ذالك مجيب.... بمعنى لم يجبه(1).

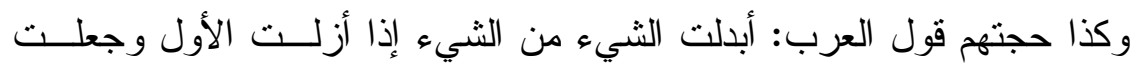
الثاني مكانه ومنه قول أبي النجم عذل الأمير للأمير المبدل...

و هذا مذهب العرب ولفظها إذا قالو ا بدلت الثيء من الثيء فمعنـــاه: غيــرت

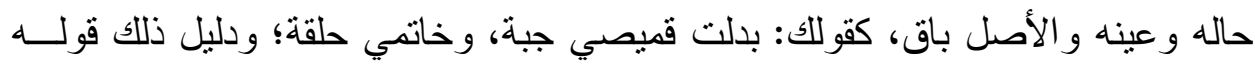

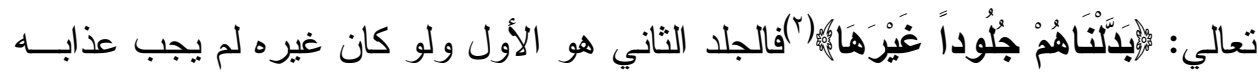

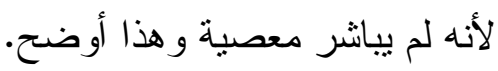

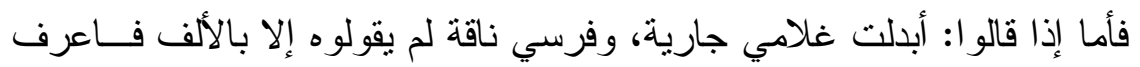

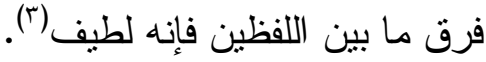
قال أبو حيان(๕): التخفيف و التشديد والمعنى واحد؛ وهو إذهاب الثيء و الإنتان

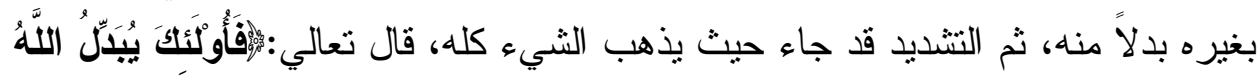

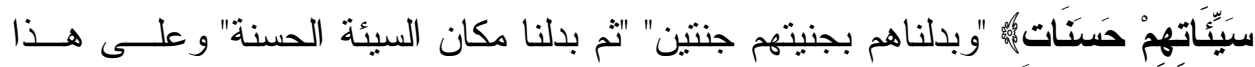

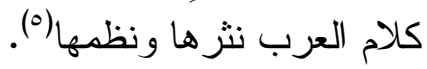
وقال أبو علي الفارسي: بدل و أبدل ينقاربان في المعنى (؟).

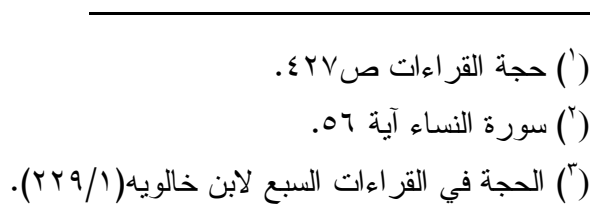

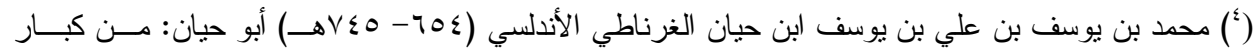

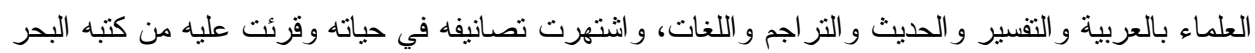

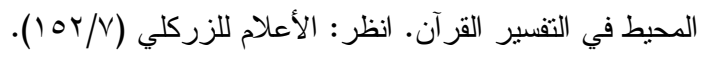

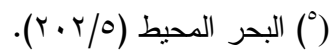

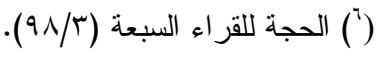


قال الطبري: والصواب من القول في ذللك عندي: أنهــــا قر اعتـان متقاربتــا

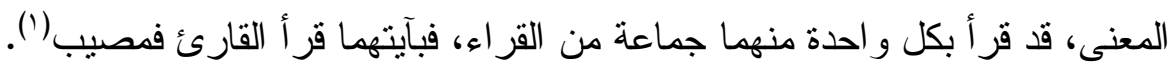
اختلفت القر اء في قوله: "و أقرب رحماً" - فقر أ ابن عامر بضم الحاء "رحما". - و وأسكنها الباقون "رحما". توجيه القر اعتين:

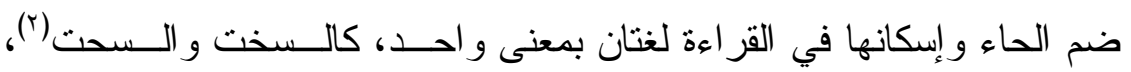
ومثلها: الرعب و الرعب. وحجة ابن عامر قول الثاعر:

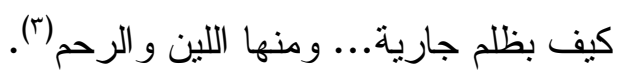

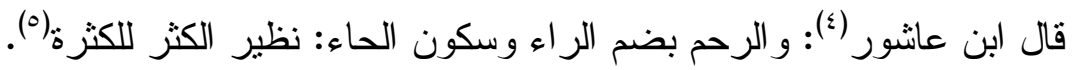
وفي معنى الكلام قو لان:

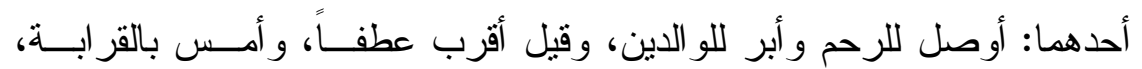

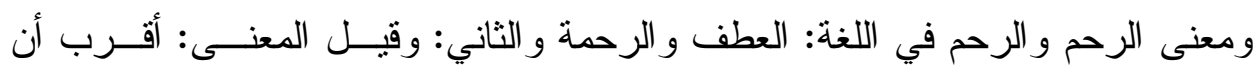

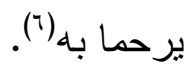

\section{(V)}

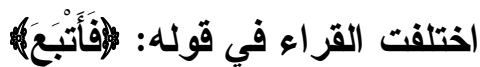
- فقر أ نافع وابن كثير و أبو عمرو بهاتيع بوصل الألف مع تشديد التاء.

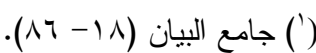

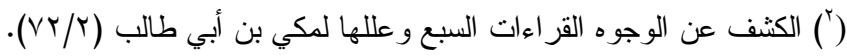

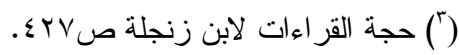

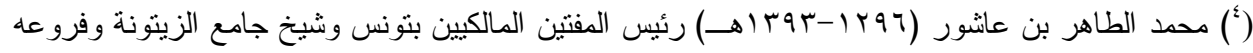

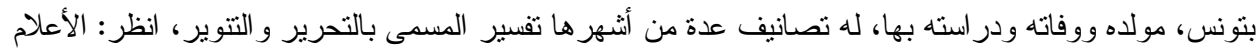

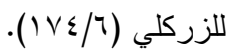

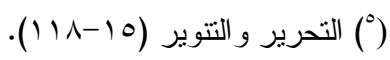

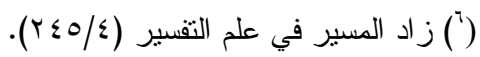
(") سورة الكهف الآية 10. 10. 
- وقر أ الباقون بهمز الألف مع تخفيف التاء(')

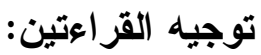

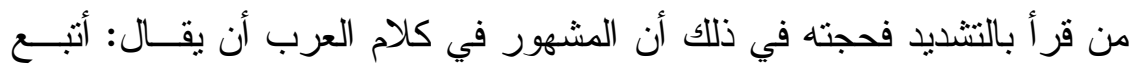

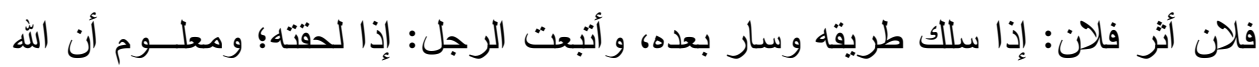

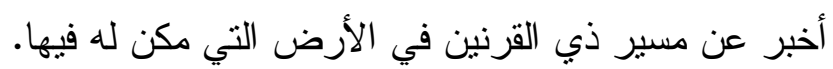

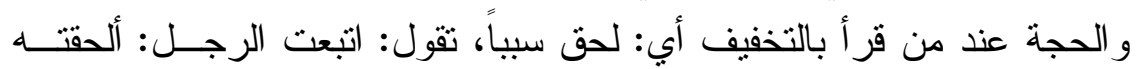

$$
\text { خيرًا أو شراً (r). }
$$

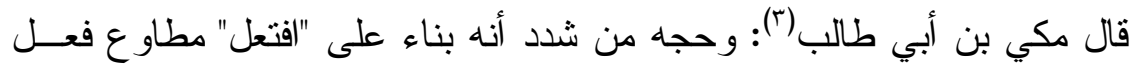

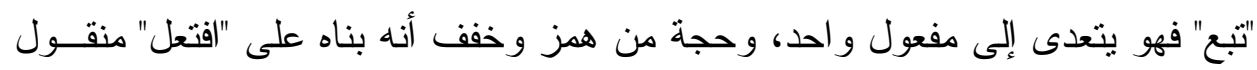

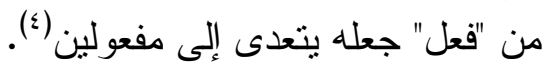

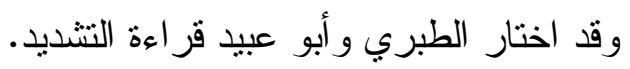

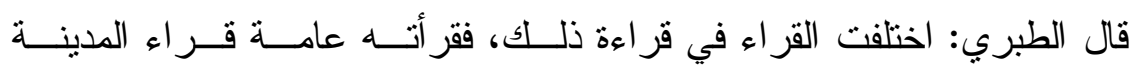

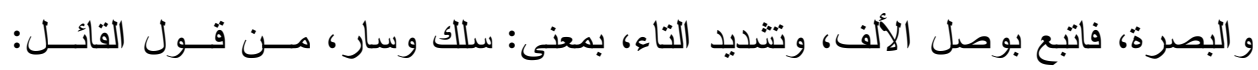

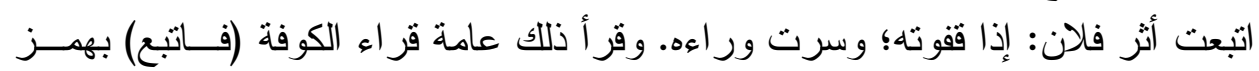

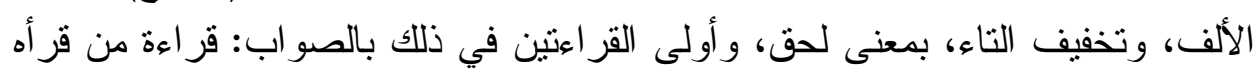

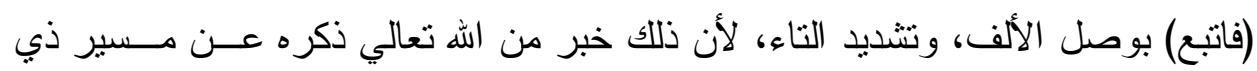

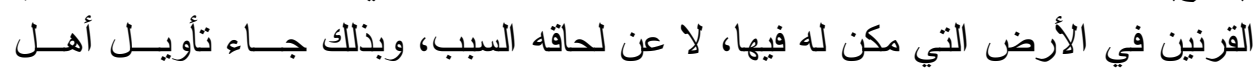
التأويل (o)

وقال أبو عبيد: القراءة عندي فاتبع بالتشديد؛ لأنها من المسير ، إنما هو افتتـلـل

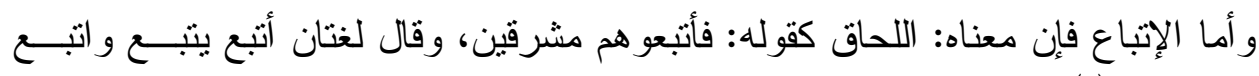

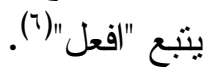

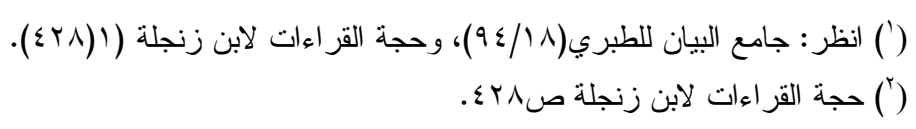

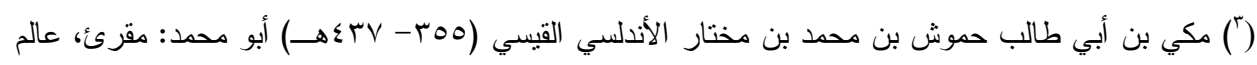
بالتفسير و العربية.

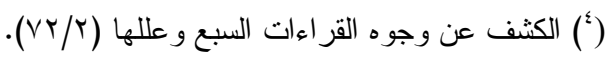

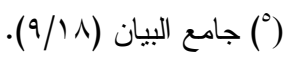

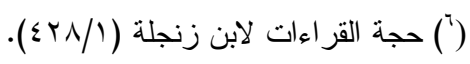


و اختار الفر اء قر اعة التخفيف فقال: و أتبع أحسن من اتبع؛ لأن معنـى اتبعـــ

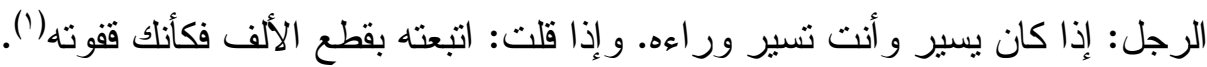

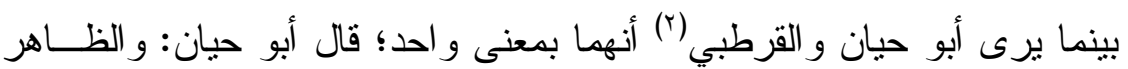

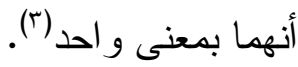
وقال القرطبي: و الحق في هذا أن "تبع و أتبع و أتبع" لغات بمعنى و احد، وهـي احسي

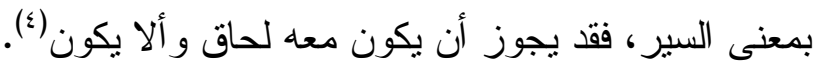

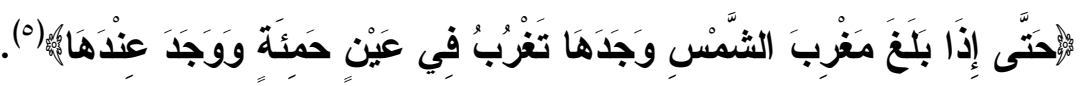

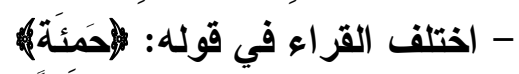
- فقرأ ابن كثير ونافع و أبو عمرو وحفه وحف ويعقوب "في عين حمئة" مهــــوزة بغير ألف.

- وقر أ الباقون "حامية" بألف غير مهموزة. توجيه القر اعثني:

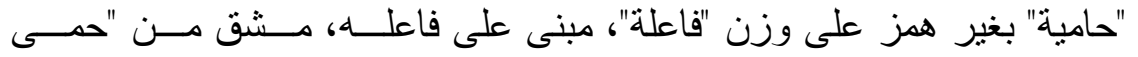

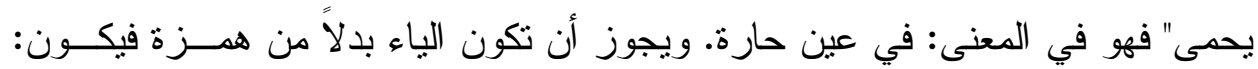

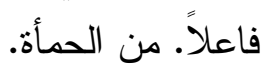

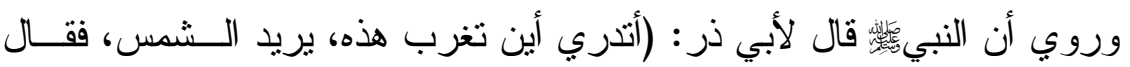

أبو ذر : الله ورسوله أعلم. فقال: إنها تغرب في عين حامية).

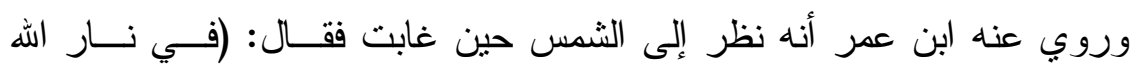

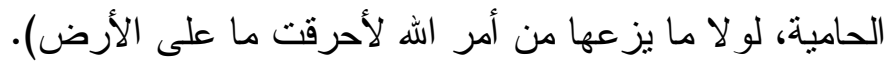
فيكون معنى الحامية: الحارة على هذين الحديثين.

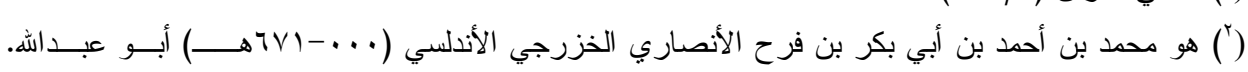

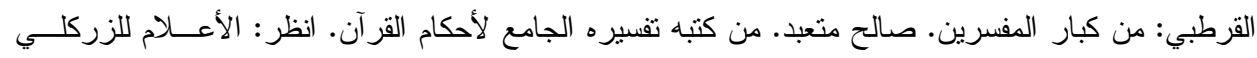
( ( TY/O)

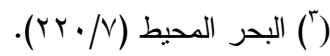

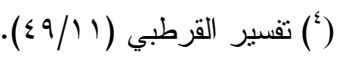
(") سورة الكهف الآية 19. 
أما من قر أ بالهمز "حمئة" فهي على وزن "فعلة" فجعله مشتقاً من "الحمــأة" أي: ذات حمأة.

وقد سأل معاوية كعب فقال له: أين تجد الثمس تغرب فــي التـور اة؟ فقــال:

$$
\text { تغرب في ماء وطين. }
$$

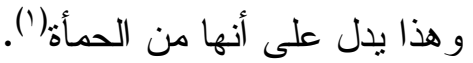

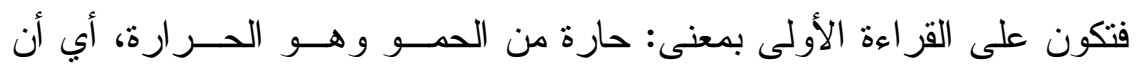
ماءها سخن.

و على القر اعة الثانية بمعنى: الطين الأسود. و المعنى: عــين مخــلطـ ماؤهــا

$$
\text { بالحماة فهو غير صاف و (r). }
$$

وقد جمع بين هذين المعنيين لكل من القر اعتين جمع من المفسرين.

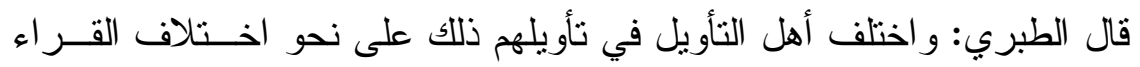

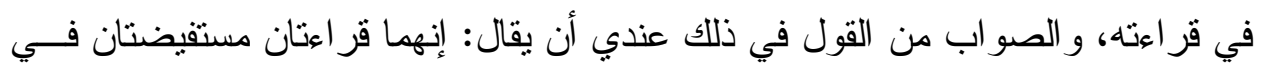

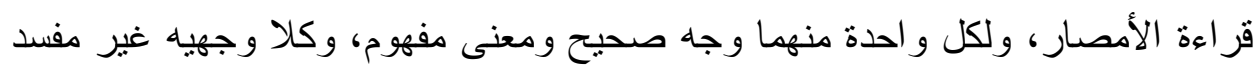

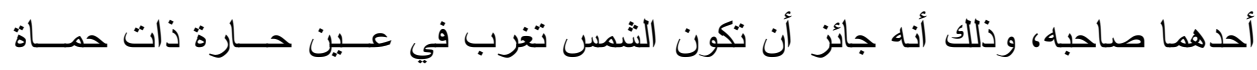
وطين، وقد روي بكلا صيغتها اللتين إنها من صفتيها أخبار (r). وقال القرطبي: وقد يجمع بين القر اعتين فيقال: كانت حارة وذات حمأة(ء).

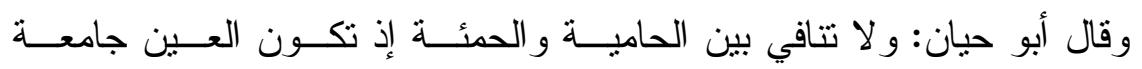
للوصفين (0)

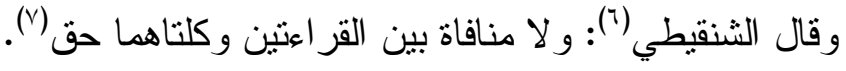

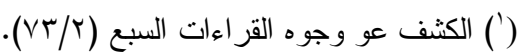

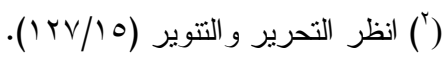

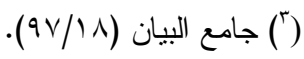

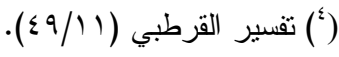

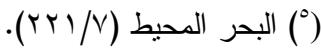

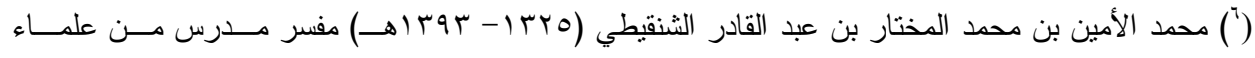

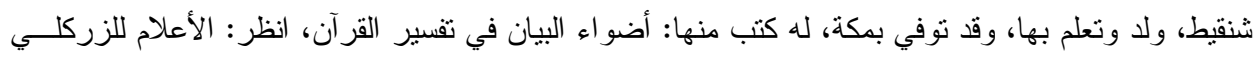




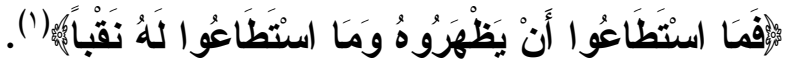

* اختلفت القراء في قوله: (اسنتَطَاعُوا).

- فقر أ حمزة بتشديد الطاء.

- وقر أ الباقون بالتخفيف.

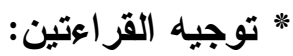

حجة من خفف بغير تاء فإن أصلها استطاعو ا بالتاء، ولكن التاء و الطـــاء مــن

مخرج و احد؛ فحذفت التاء للتخفيف ولمو افقة الخط.

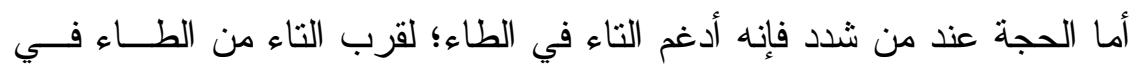

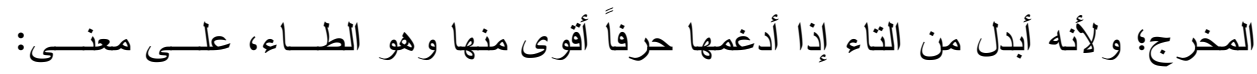
استطاعو ا، وفيه جمع بين ساكنين و هما السين و التاء المدغمة في الطاء.

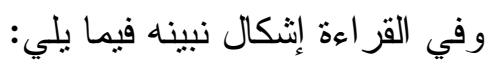

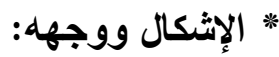

الإشكال ورد على قر اءة التشديد بإدغام التاء في الطاء، وهو "إثكال لغوي".

وجه الإشكال: الجمع بين الساكنين، وليس الأول منهما حرف لئ لين.

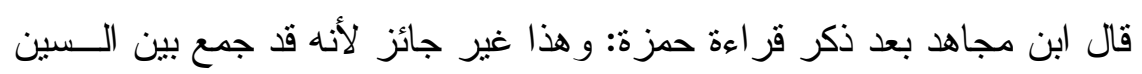

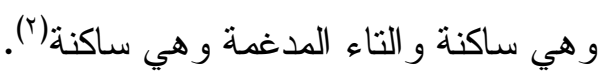

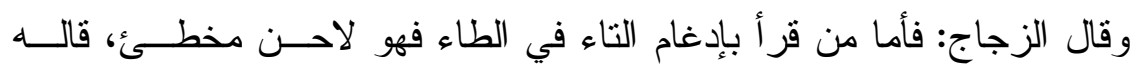

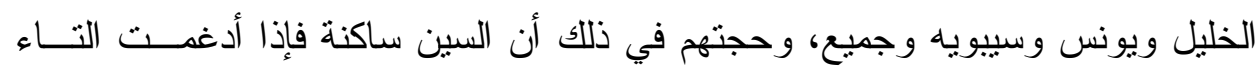

صارت طاء ساكنة و لا يجمع بين ساكنين (َ).

وقال مكي: في هذه القر اعة بعد وكر اهة لأنه جمع بين ساكنين(أله

$$
\begin{aligned}
& \text { (') (') سورة الكهف الآية 9v. }
\end{aligned}
$$

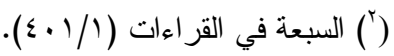

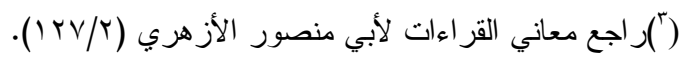

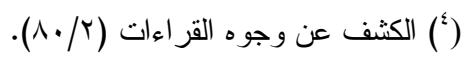


قال المبرد('): لا يقدر أحد أن ينطق به، وإنما يروم الجمع بين ساكنين ويحرك

و لا بأتيه (r)

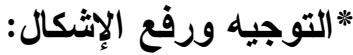

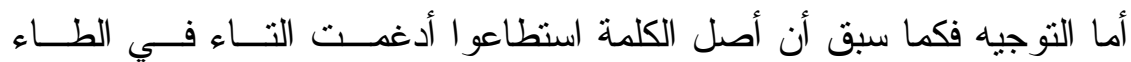
فصارت طاء مشددة، فاجتمع ساكنان ثانيهما على حرف مشن مشدد.

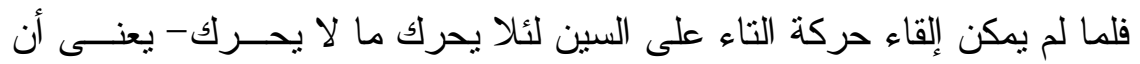

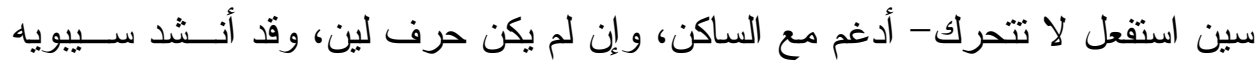
"ومسحي) يعنى في قول الثاعر : كأنه بعد كلال الزاجر ... ومسحي مر عقاب كاسر

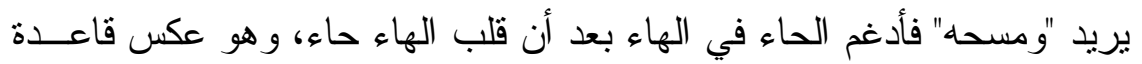

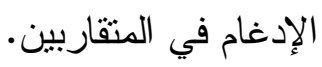

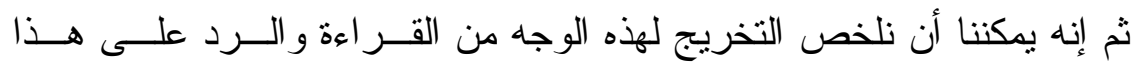

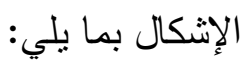

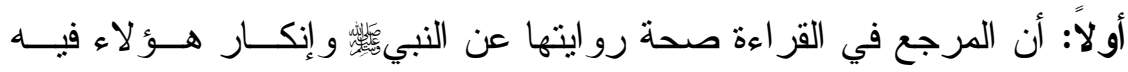

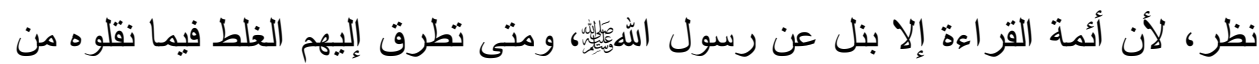

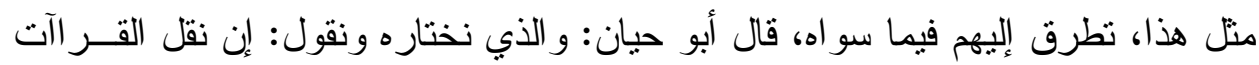
السبع متو اتز لا يمكن وقوع الغلط فيه فَّان. ثانياً: إذا أنكر نحوى القر اعة بحجة مخالفتها لقاعدة تو اطأ عليها النحاة، و أنكــر

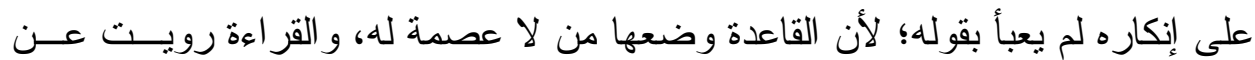
معصوم، و المعصوم لا يقر على خطأ. ثالثاً: أن هذه القر اعة مروية عن الإمام حمزة رحمه الله تعالي، وحمــزة مــن الأئمة الفصحاء وقد تلقاها ولم ينكر ها.

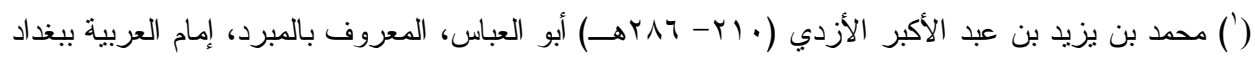

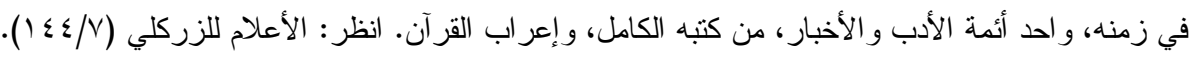

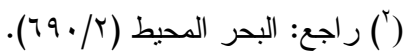

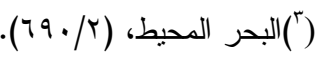


رابعاً: أن الجمع بين الساكنين في مثل هذا لغة من لغات العرب، ولها نظــائر

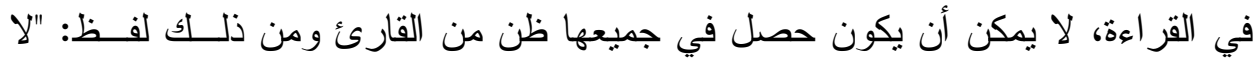

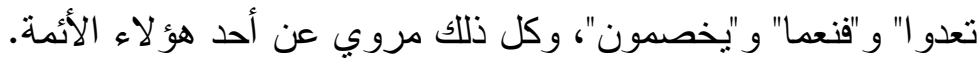

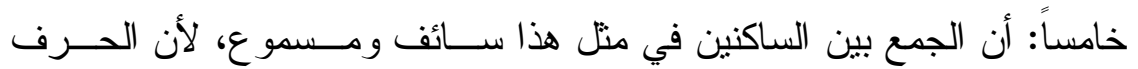
المشدد كالحرف المتحرك يرتفع اللسان عند النطق به ارتفاعه و احد لـأ.

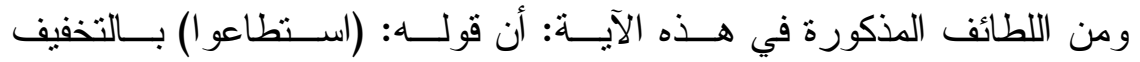

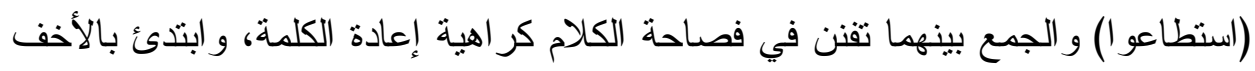
منهما لأنه وليه الهمز وهو حرف تقيل لكونه من الحلق، بخلاف الثاني إذ وليــه الــلام وهو خفيف.

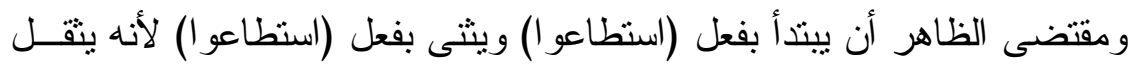

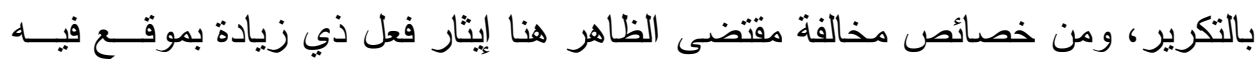

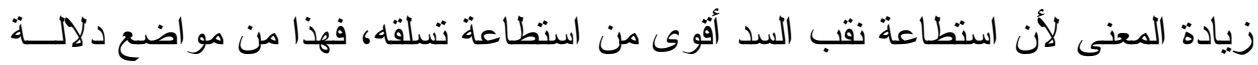
زيادة المبنى على زيادة في المعنى (؟).

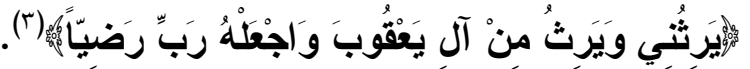

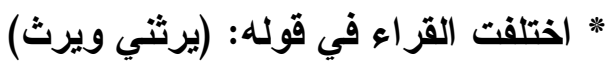

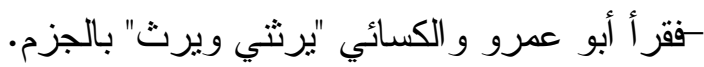

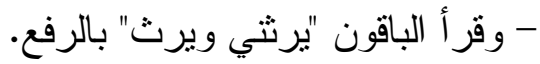

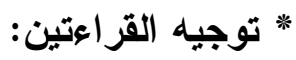

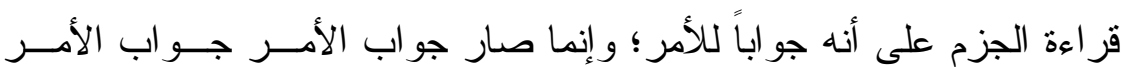

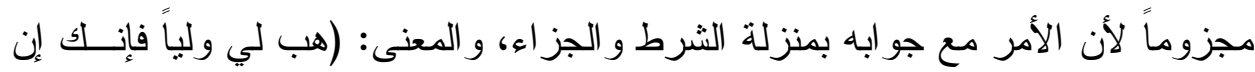
و هبته لي ورثني).

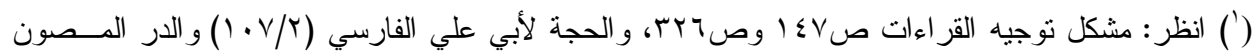
(r)

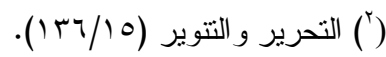
(") سورة مريم. 


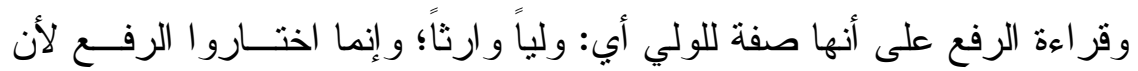

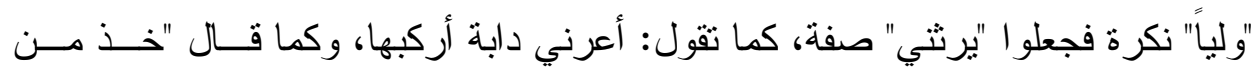

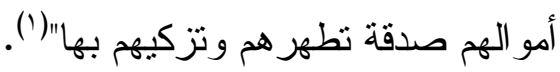

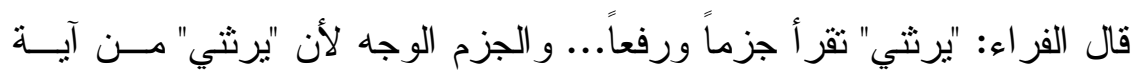

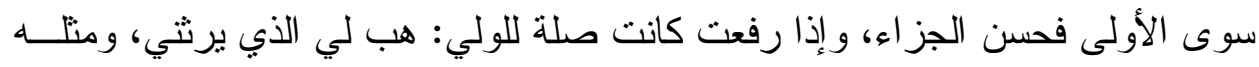

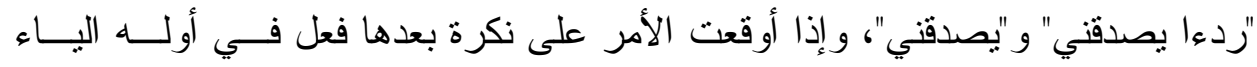
و التاء و النون و الألف كان فيه وجهان: -الجزم على الجزاء و الثرط.

- و الرفع على أنه صلة للنكرة بمنزلة الذي، كقول القائل: أعرني دابة أركبها،

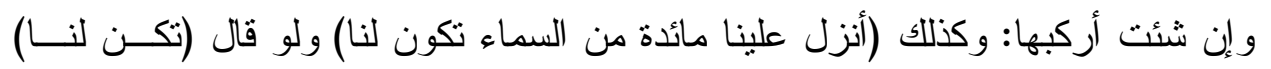
كان صو اباًُ (r) قال الطبري: قال أبو جعفر : وأولي القر اعتين عندي في ذلك بالصو اب قــر اءة

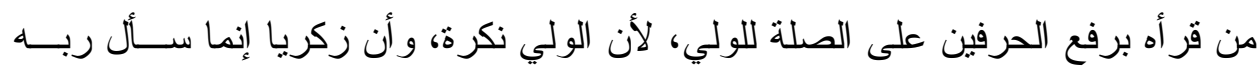

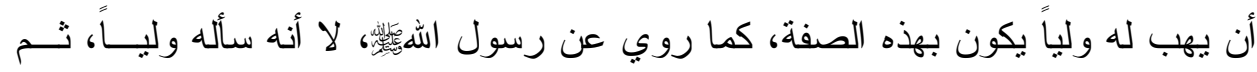
أخبر أنه إذا وهب له ذلك كانت هذه صفته، لأن ذلك لو كان كذللك، كان ذلك من زكريا دخو لاً في علم الغيب الذي قد حجبه الهه عن خلقه لَّا.

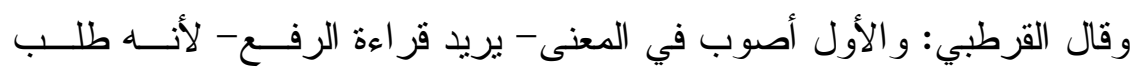

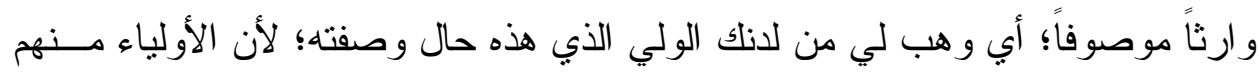

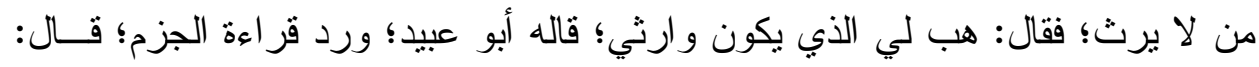

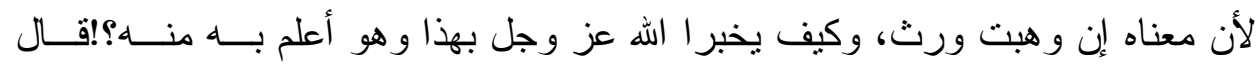

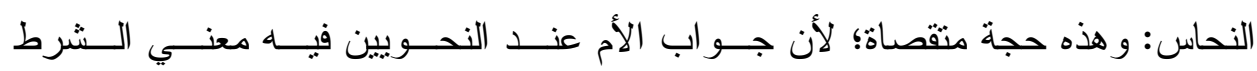

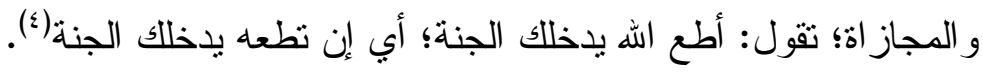

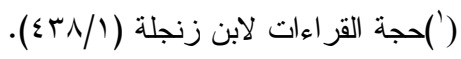

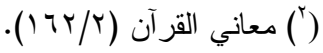

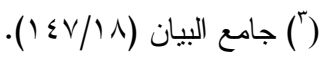

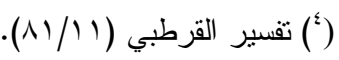




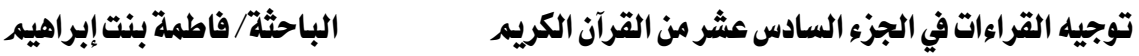

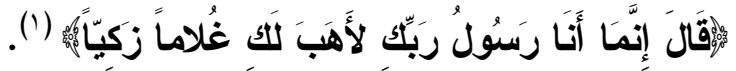

* (ختلف القراء في قوله: (لأََبَ).

- فقر أ أبو عمرو بالياء من غير همز (لاهب) "ليهب".

- وقر أ الباقون بالهمز "لأهب".

* توجيه القراعتين:

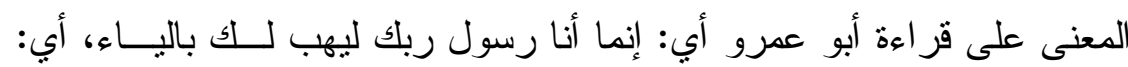

(ليهب الله للك) ولم يكن جبريل الذي يهب بل الله يهب، المعنى أرسلني ليهب اله للك.

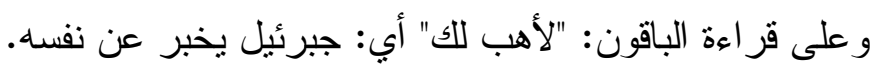

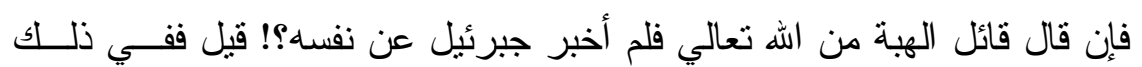

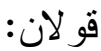

أحدهما: قال إنما أنا رسول ربك، يقول الهه تعالي: "لأهب للك".

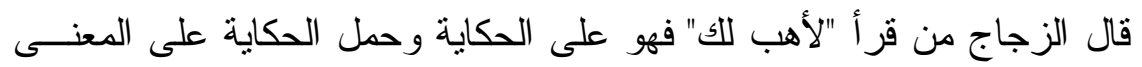

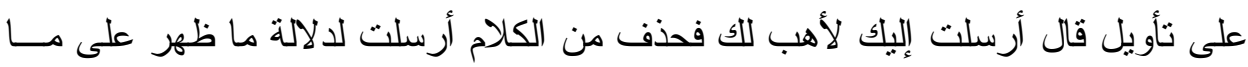

حذف.

وثانيهما: جبريل عليه السلام قال لمريم: إنما أنا رسول ربك أرسلني لأهب للك

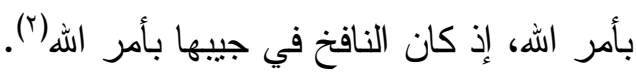

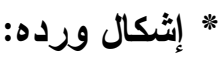

ورد إثكال على قر اءة أبو عمرو بالياء "ليهب للك" على معنى ليهب الله للك.

قالو ا: هذه القر اءة ضعيفة لأنها جاءت على خلى خلاف المصحف.

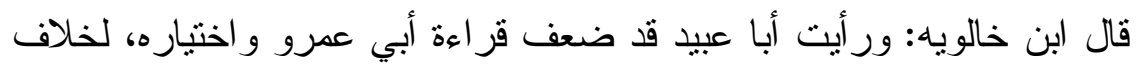

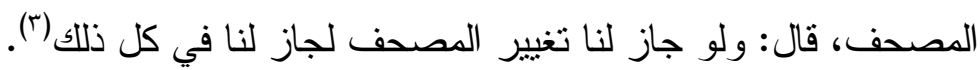

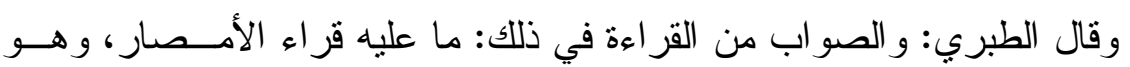

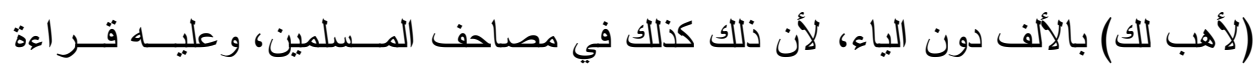

(') (') (') سورة مريم : (') (')

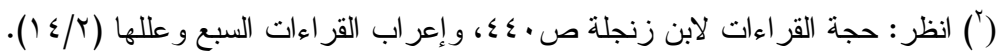

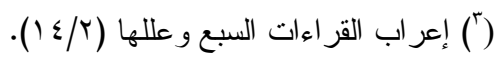


قديمه وحديثهم، غير أبي عمرو، و غير جائز خلافهم فيما أجمعــو ا عليـه، و لا سـائغ لأحد خلاف مصاحفهر (').

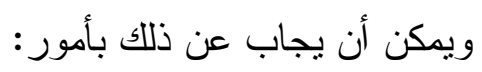

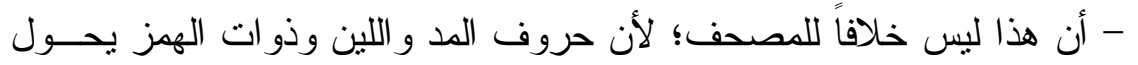

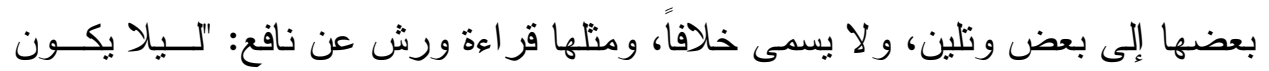

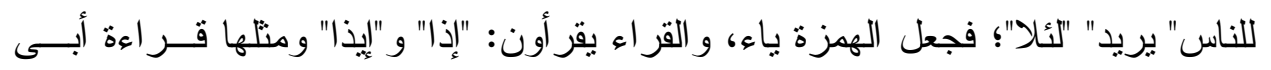

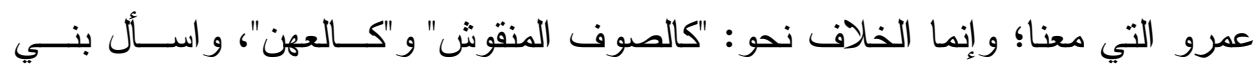

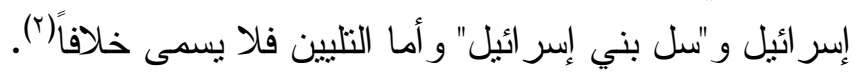
- أن هذه القراءة مروية عن أبي عمرو وهو إمام من أئعة القر اءات العـشرة فئاة

وقد تلقاها بالتو اتز ولم ينكر ها.

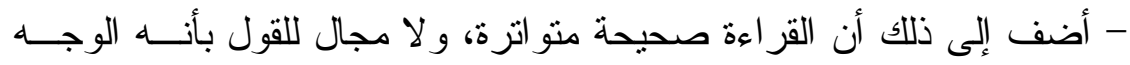

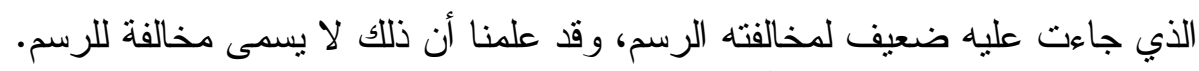

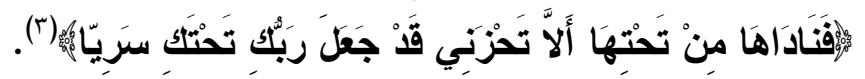
* (ختلف القراء في قوله: (منْ تَحْتِهَا).

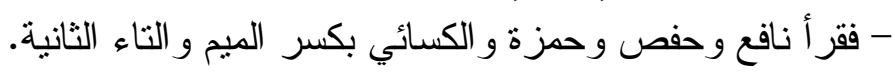
- وقر أ الباقون بفتح الميم و التاء الثانية.

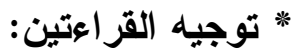

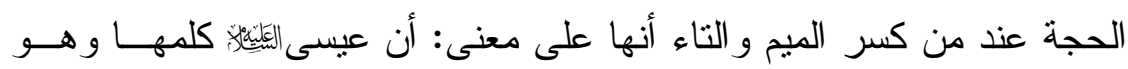

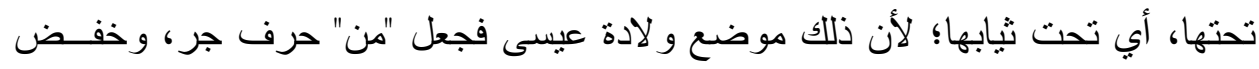

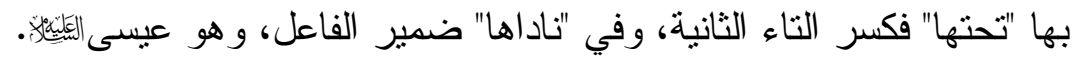

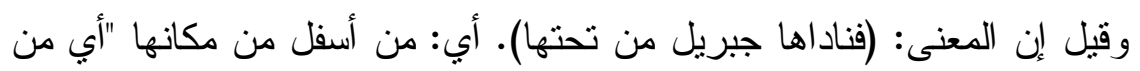

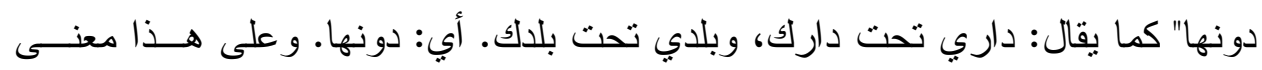

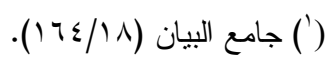

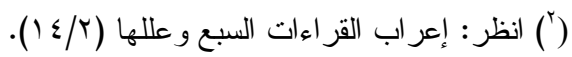
(") سورة مريم. 
قوله تعالى: "قد جعل ربك تحتلك سريا" أي: دونك نهراً تستمتعين به، فليس المعنـى إذا

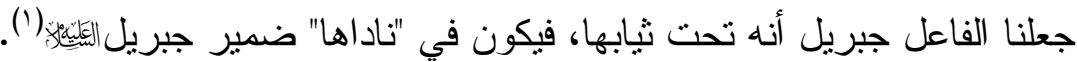

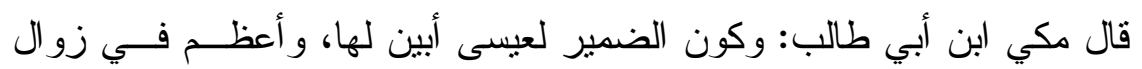

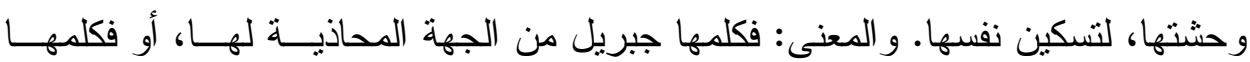
عيسى من موضع و لادته؛ وذللك تحت ثيابها (؟).

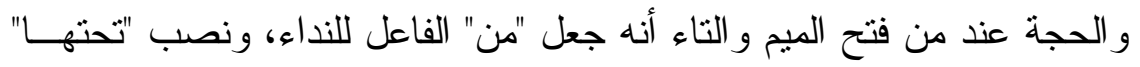

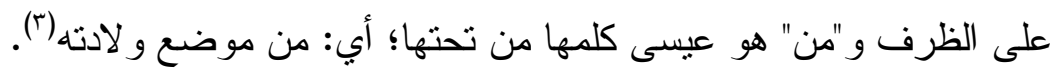

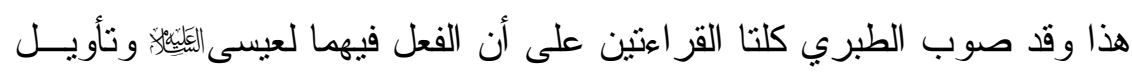

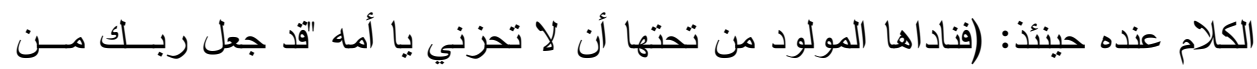
تحتلك سريا" (๕). وكذا ذهب الثيخ الثنقيطي إلى أن الذي ناداها هو أبنها عيسى، وذكر قرينتــان تذل على هذا:

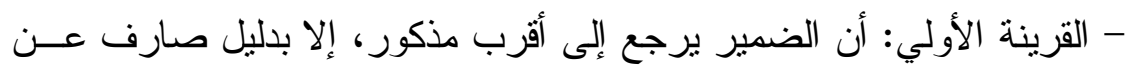

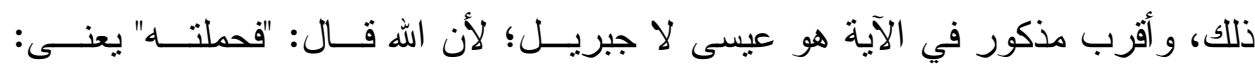

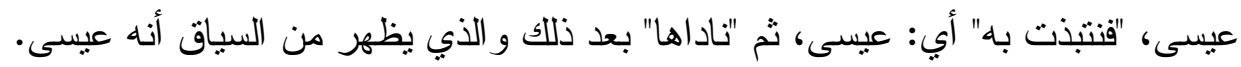

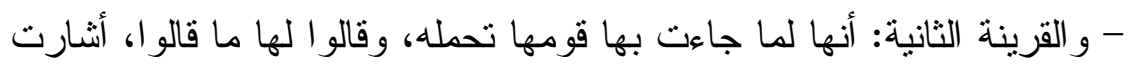
إلى عيسى ليكلموه كما أخبر بذلك القرآن، و إثنارتها إليه ليكلموه قرينة على أنها عرفت

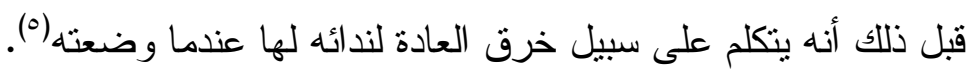

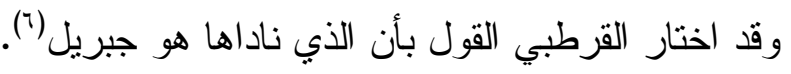

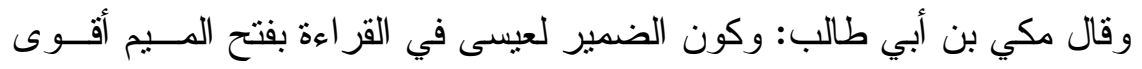

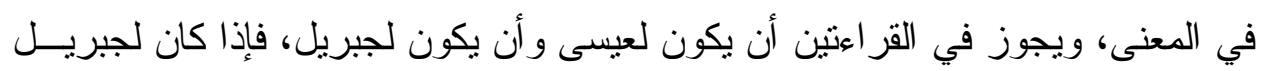

$$
\begin{aligned}
& \text { (') الكثف عن وجوه القر اءات لمكي بن أبي طالب (TV/Y). }
\end{aligned}
$$

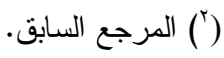

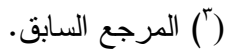

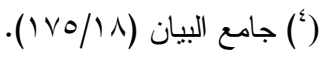

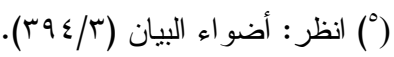

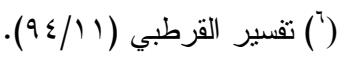


كان معنى "تحتها" دونها، أسفل منها، و إذا كان لعيسى كان معنى "تحتها" تحت ثيابهــا،

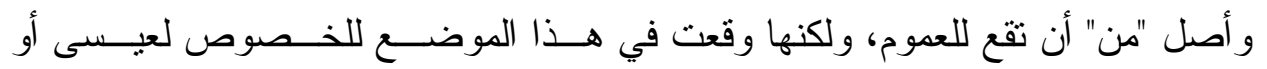

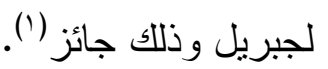

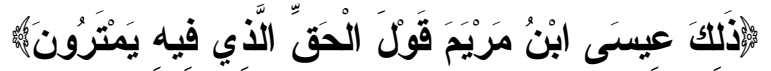
*تلفت القراء في قوله: (قول الحق).

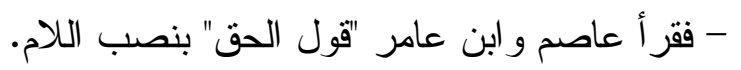
- وقر أ الباقون "قول الحق" واهن عالرفع.

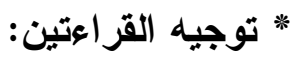

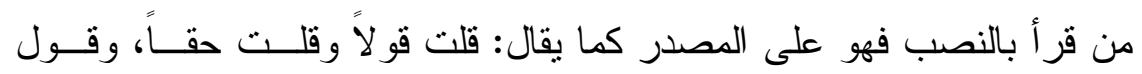
الحق: قول الله؛ فاله جل وعز أخبر عن نفسه بأني أقول قول الحق بأن عيسى هو ابـنـ مريم.

ومن قر أ بالرفع: فمن وجهين: - أحدها: أن يجعل قول أرفع: فمن وجناً لعيسى.

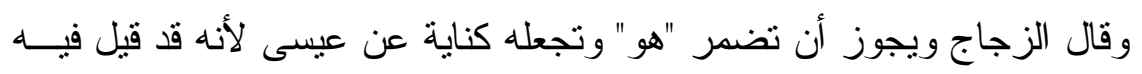

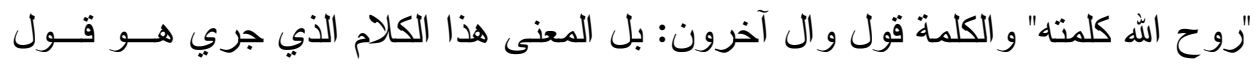
الحق (r) (لدوح) قال الفراء: وقد قرأت القراء بالنصب (قول الحق) وهو كثير يريدون به: حقا.

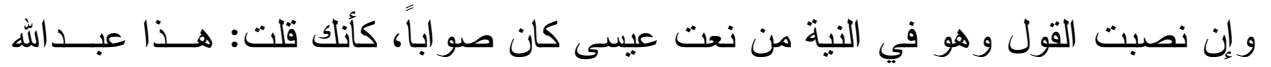

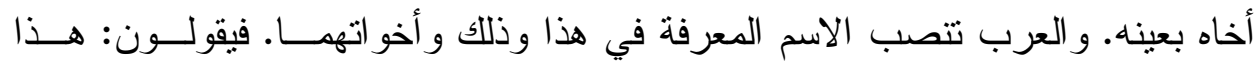
عبداله الأسد عادياً كما يقولون: أسداً عادياً (َ).

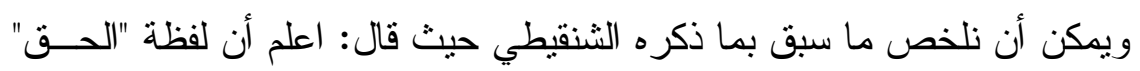

$$
\text { في قوله: "قول الحق" للعلماء فيها وجهان: }
$$

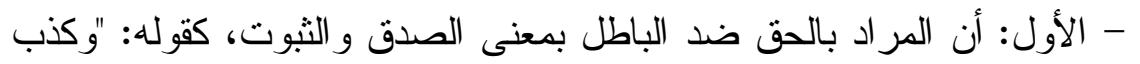
به قومك وهو الحق" وعلى هذا القول فإعر اب قوله: "قول الحق":

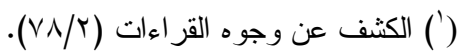

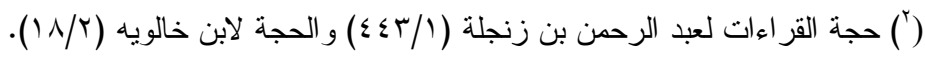

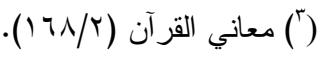




$$
\text { * و على قر اءة النصب: أنه مصدر مؤكد لمضمون الجملة. }
$$

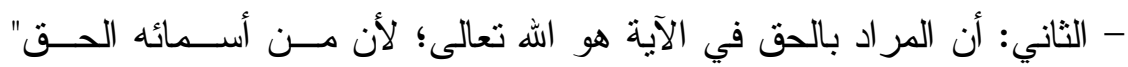

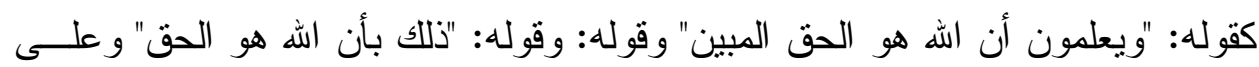

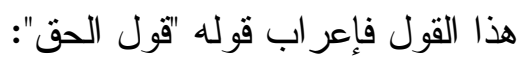

$$
\text { * على قر اعة النصب أنه منصوب على فولى المدح. }
$$

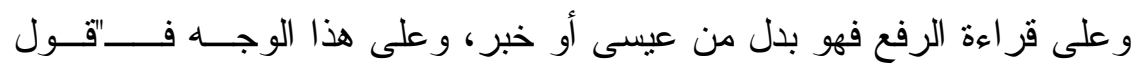

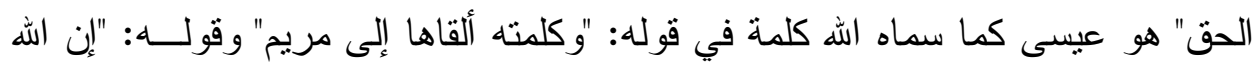

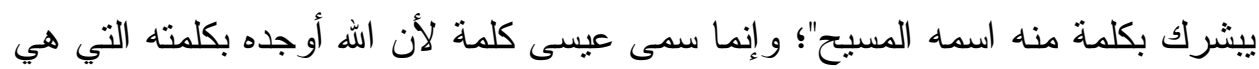

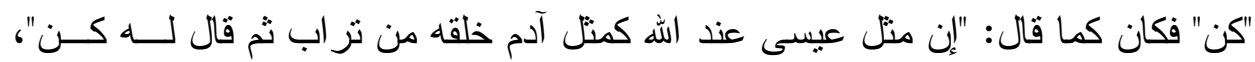
و القول و الكلمة على هذا الوجه من التقسير بمعنى و احد (').

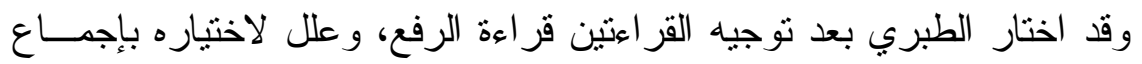

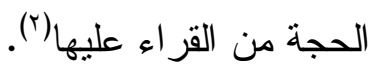

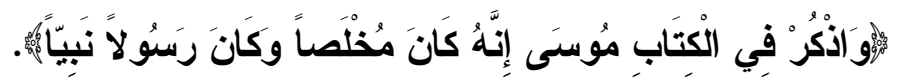

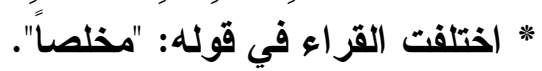

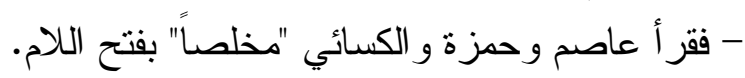

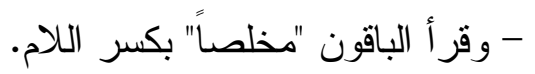

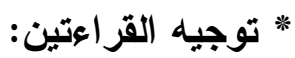
من قر أ بالفتح جعل المعنى أي: أخلصه الهه و اختاره وجعله خالصـاً من الــنس

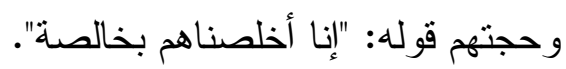
ومن قر أ بالفتح جعل المعنى أي: أخلصه الله واختاره وجعله خالصاً من الدنس

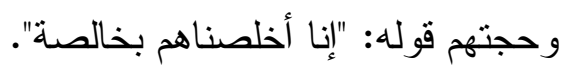
ومن قر أ بالكسر جعل المعنى أي: أبي أخلص هو الله. التوحيد فصـار مخلــــاً. وجعل نفسه خالصةً في طاعة الله، وحجتهم قوله: "مخلصين له الدين الدين"(").

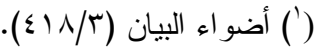

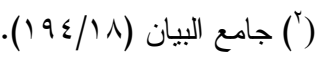

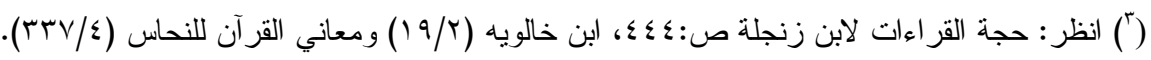


وبنحو هذا التفسير فسره الطبري حيث ذكر أن قر اعة الكسر مــن المخلــص،

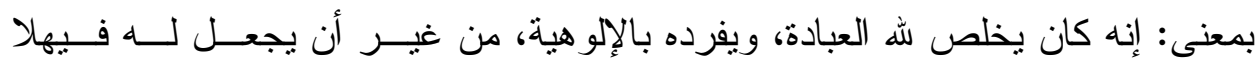

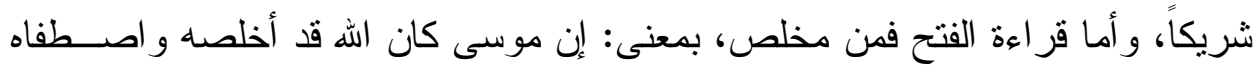
لرسالته، وحمله نبياً مرسلاً.

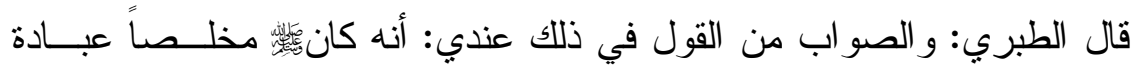

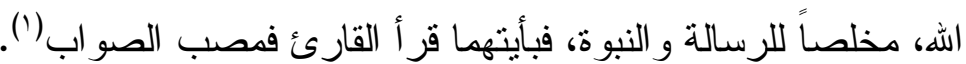

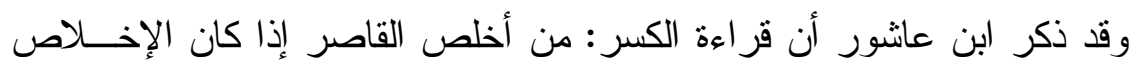

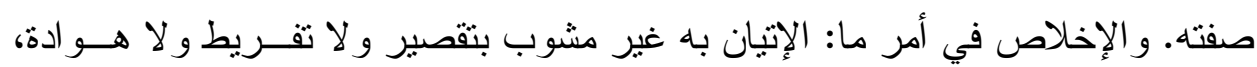
مشتق من الخلوص، وهو التمض وعدم الخلط. و المراد هنا: الإخلاص فيما هو شأنه، وهو الرسالة بقرينة المقام.

و أما قر اءة الفتح فهي من: أخلصهاه، إذا اصطفاه.

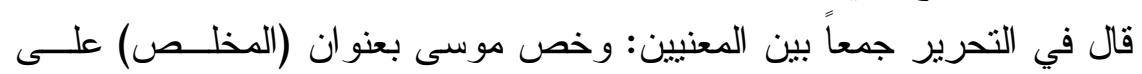
الوجهين - أي المعنيين السابقين - لأن ذلك مزيته:

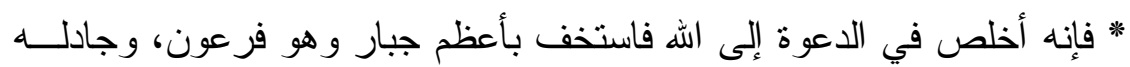

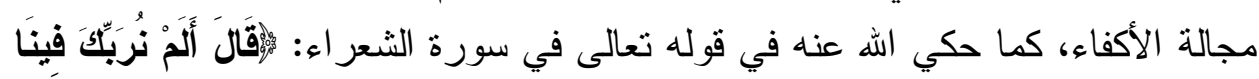

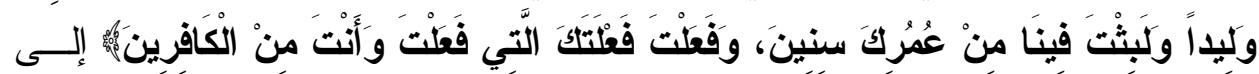

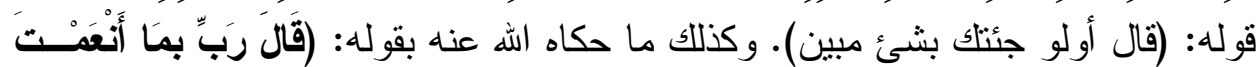

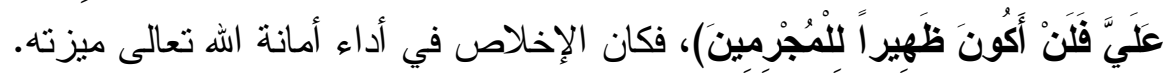

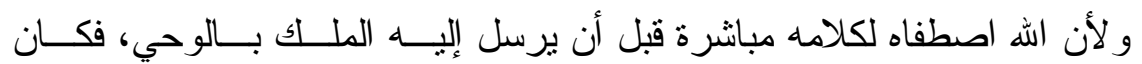

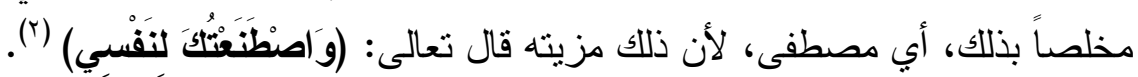

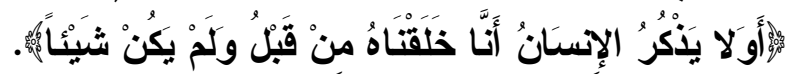

* اختلفت القراء في قوله (يأكر)

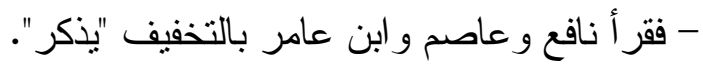

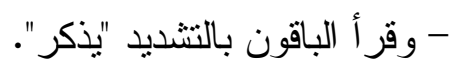

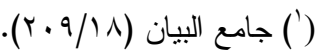

$$
\begin{aligned}
& \text {. (0 (17) (1) }
\end{aligned}
$$




\section{* توجيه القراعتين:}

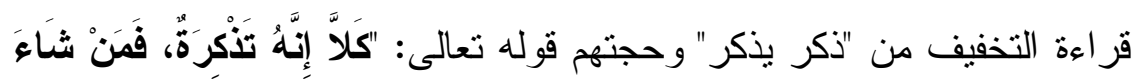

ذَكَرَهُ" و المعنى أي: أو لا يتدبر ، ويتفكر ؟! (').

هذا وقد اختار مكي بن أبي طالب قر اعة التشديد فقال:

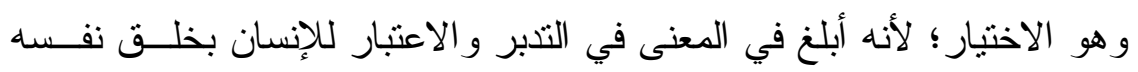

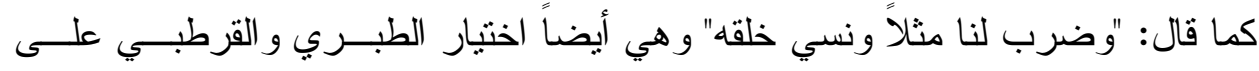
المعنى السابق:

قال الطبري: والتشديد أعجب إلى، و إن كانت الأخرى جائزة؛ لأن معنى ذلك:

أو لاً يتقكر فيعنبر (r).

وقال القرطبي: و الاختيار التشديد و أصله يتذكر لقوله تعالي "إنما يتذكر أولــوا

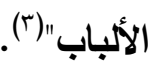

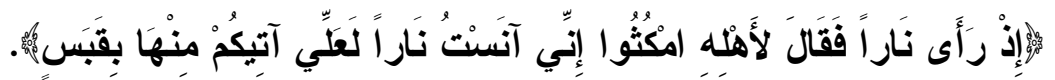

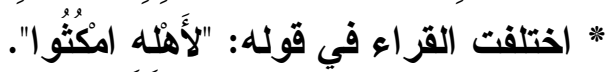

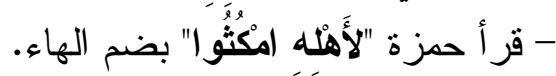

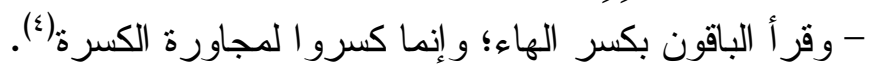

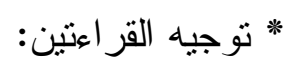

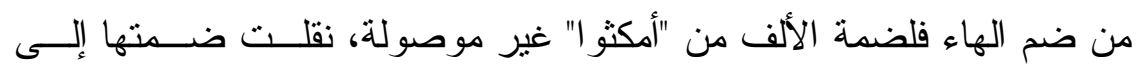

الهاء، و على لغة من يقول مررت به يا فتى (ْ).

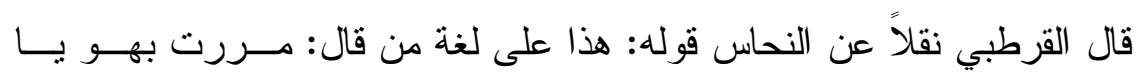

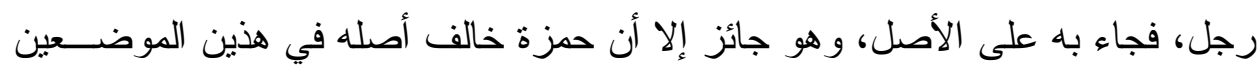

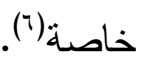

$$
\begin{aligned}
& \text { (') انظر : حجة القر اءات لبن زنجلة صه؟ ؟. }
\end{aligned}
$$

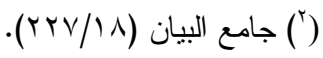

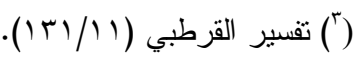

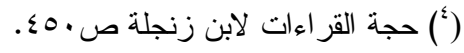

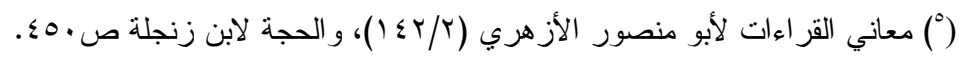

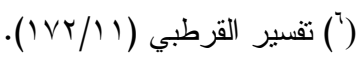




\section{ومن قر أ بكسر الهاء فعلى الأصل (').}

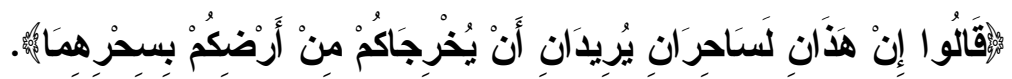

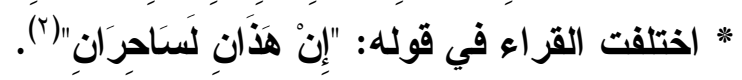

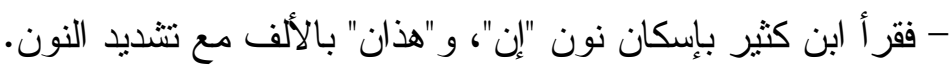

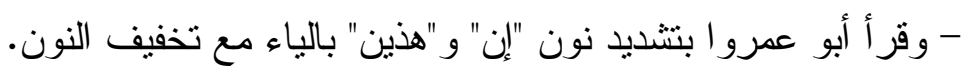
- وقر أ حفص بإسكان نون "إن" و "هذين" بالألف مع تخفيف النون.

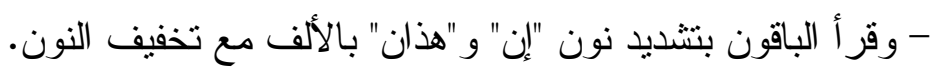

* توجيه القزاءع: وات

- على قر اءة ابن كثير : تكون "إن" بمعنى "ما"، و الأصل في "هذان": (هــذا ان)

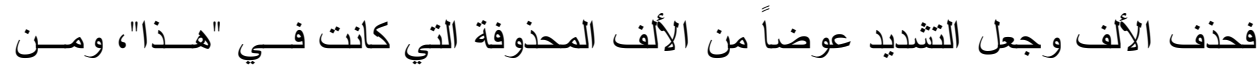
العرب من إذا حذف عوض، ومنهم من إذا حذف لم يعوض؛ فمن عــوض آنــر تمـــام الكلمة، ومن لم يعوض آثر التخفيف.

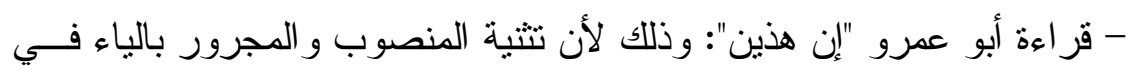
لغة فصحاء العرب، وأبو عمرو مستغن عن إقامة دليل على صحتها.

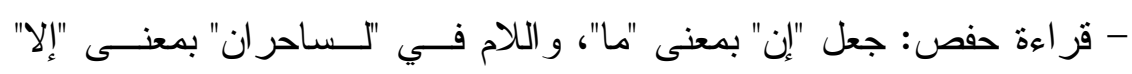
و التقدير : "ما هذا إلا ساحر ان". حفم: جعان.

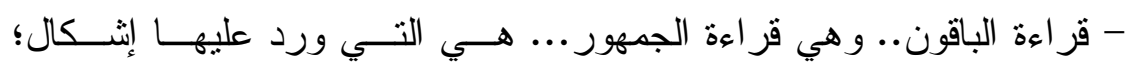
وسنتابع فيما يلي الإشكال وتوجيه القر اعة ومن ثم الرد على الإثة أشكال الوارد.

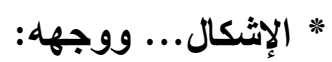

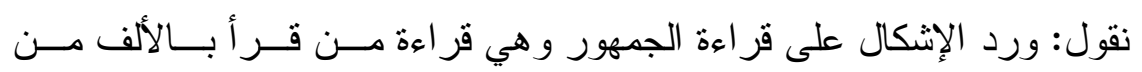

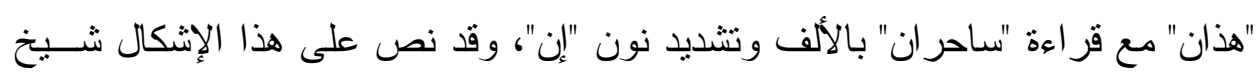

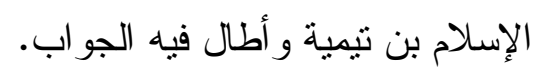

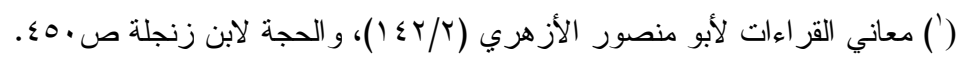

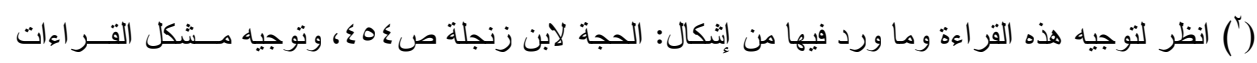

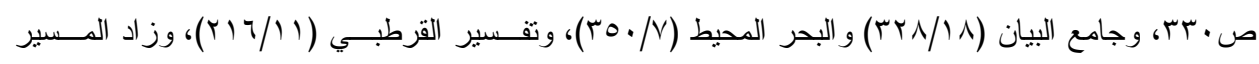
( ( 


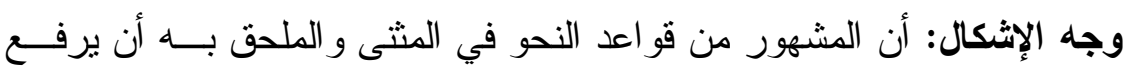

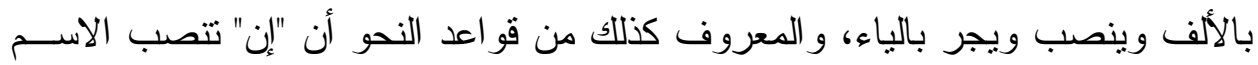

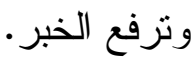

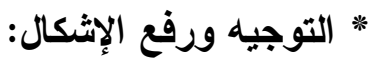

قد أجاب العلماء عن ذلك بعدد من الإجابات نلخص بعضها بما بدفع الإثــكال إن شاء الله.

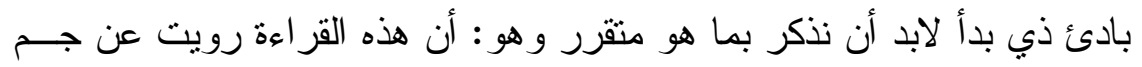

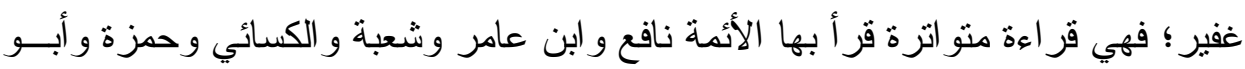

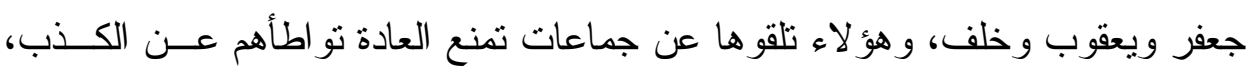

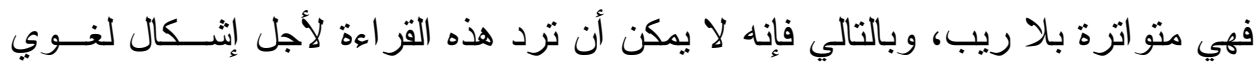

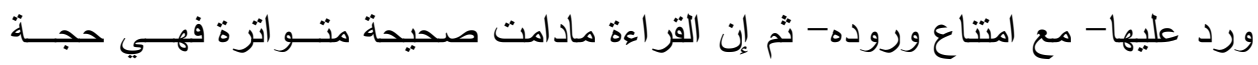
بذاتها على اللغة، وليست اللغة حجة على القز اءة فافهم ذلك رعالك الله.

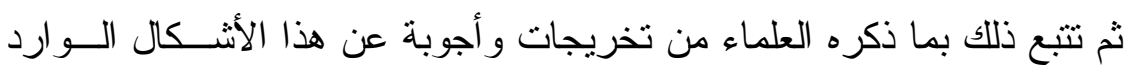
على قر اعة الجمهور ومنها:

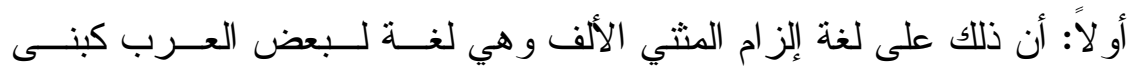
الحارث بن كعب وكنانة وختعم وغير هم، ومن شو اهده:

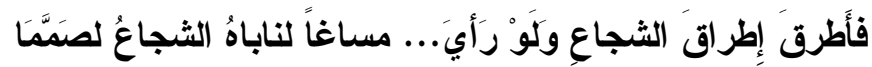
أي: لنابيه. ويقولون: كسرت يداه وركبت علاه؛ أي: يديه و عليه؛ قال شاعرهم:

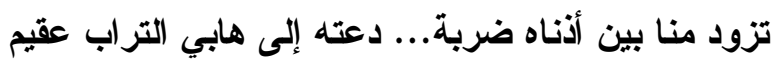

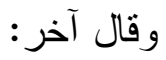

طاروا علاهن فطر علاها... أي عليهن وعليها

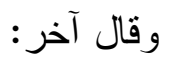

إن أباها وأبا أباها... قد بلغا في المجد غايتاها أي إن أبا أبيها و غايتها.

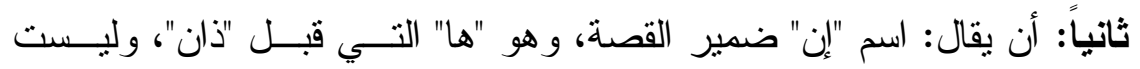

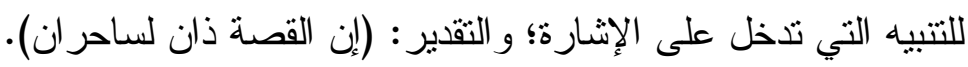


ثالثاً: أن يكون اسم "إن" ضمير الثأن محذوفاً، و الجملة من المبتدأ والخبر بعده

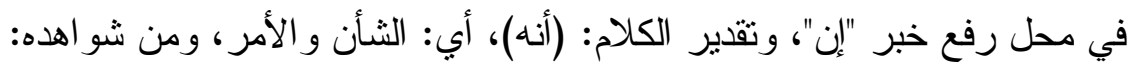

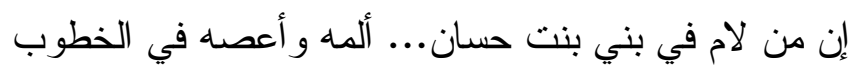
رابعاً: أن تكون "إن" بمعنى "ما"، و اللام بمعنى "إلا"، وتقدير الكلام: (ما هذا إلا لإن

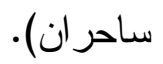
خامساً: أن يكون ألف "هذان" ألف الأصل الذي هو "هذا"، وحذفت الألف التـي

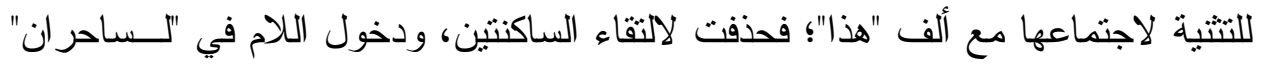
حسن لأنها دخلت على خبر "إن".

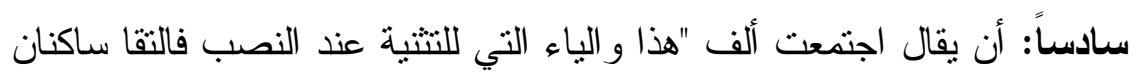
فحذفت الياء لالتقاء الساكنتين و أقرت الألف. لفعال.

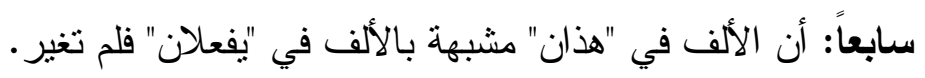

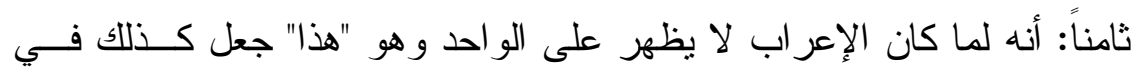

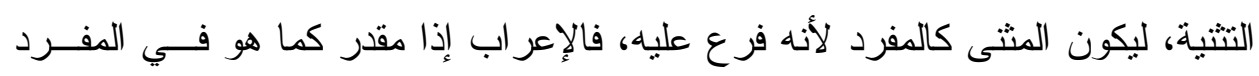
(و اختاره ابن تيمية). تاسعاً: أن تكون "إن" "بمعنى "نعم"، و "هذان" مبتدأ، و "لساحر ان" خبره.

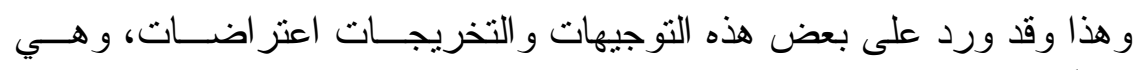

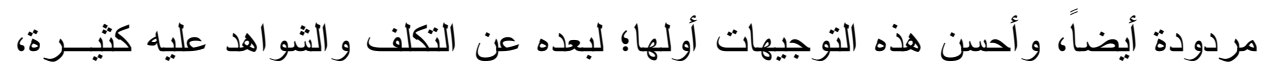

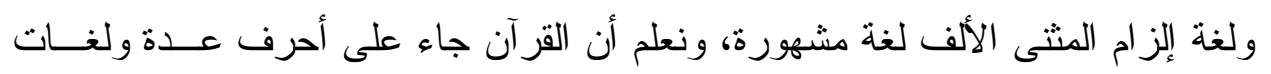
شتى فلا غر ابة أن يكون في القرآن وجه ورد على لغة لبعض قبائل العرب المشهورة.

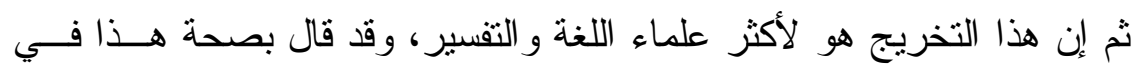

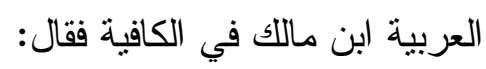
إلا قليلاً. و المثنى قد يرد.... بألف في كل حال فاعتمد

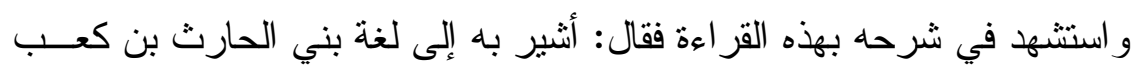

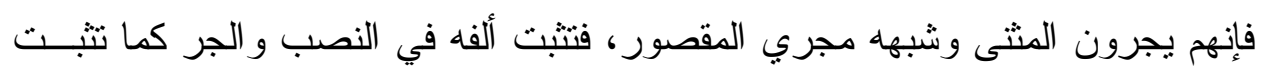

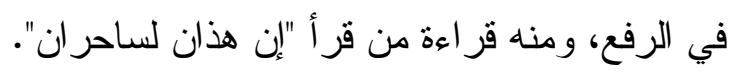

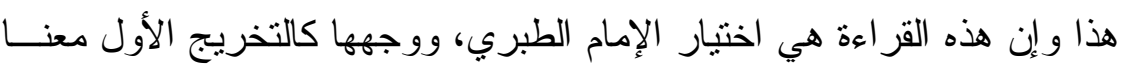
و أنها على لغة بعض العرب قال الطبري: 


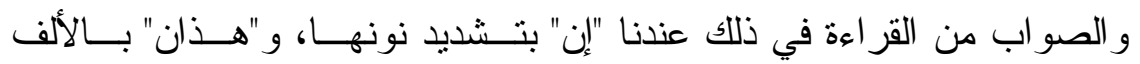

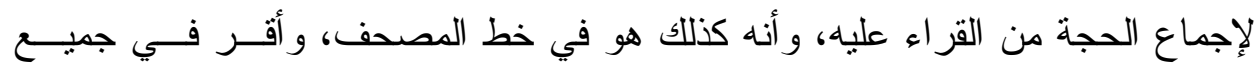

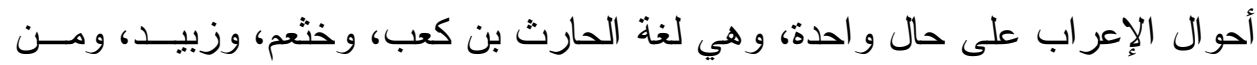

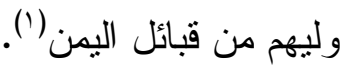

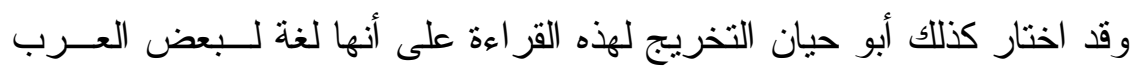

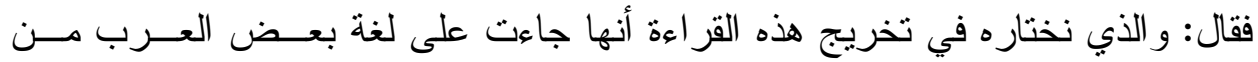

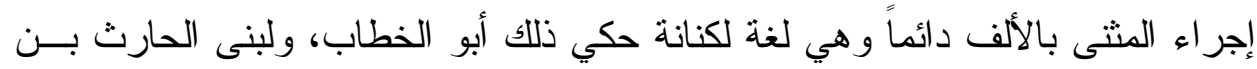
كعب وختعم وزبيد وأهل تلك الناحية حكي ذللك عن الكسائي، ولبني العنبر وبني الهجيم

ومر اد وعذرة. وقال أبو زيد: سمعت من العرب من يقلب كل ياء ينفتح ما قبلها ألفاب(؟).

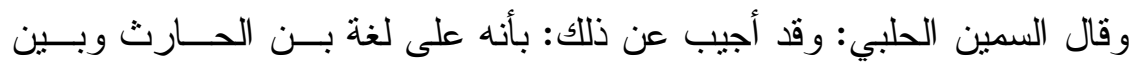

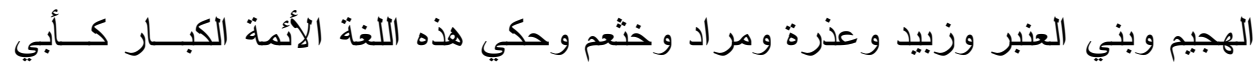
الخطاب و أبي زيد الأنصاري و الكسائي ().

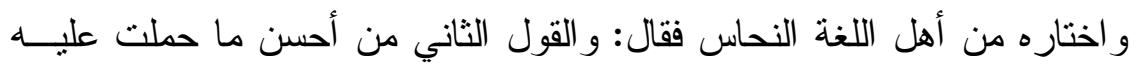

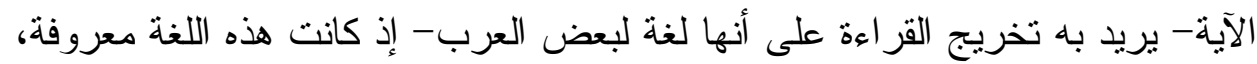

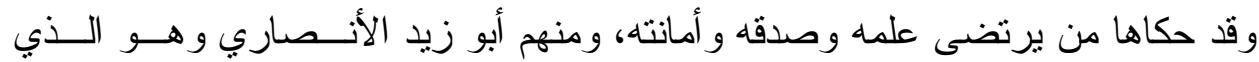

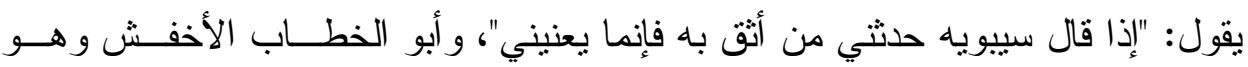

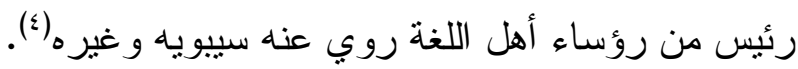

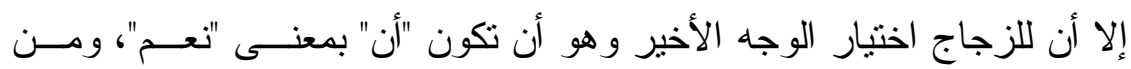

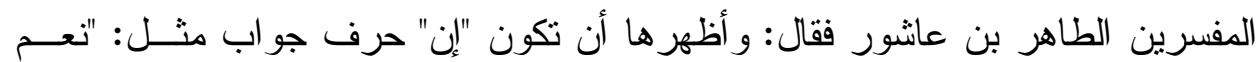

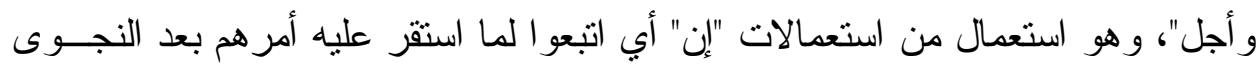
كقول عبد الله بن قيس الرقيات:

ويقلن شيب قد علاك.... وقد كبرت فقلت إنه

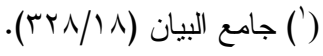

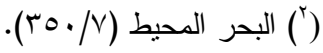

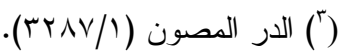

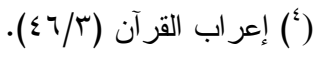


أي أجل أو نعم، و الهاء في البيت هاء السكت، وقــول عبـــالله بــن الزبيـر

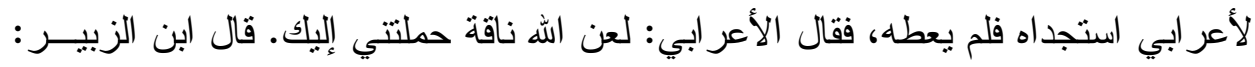

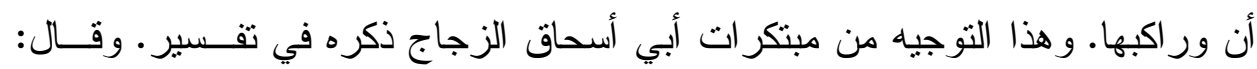

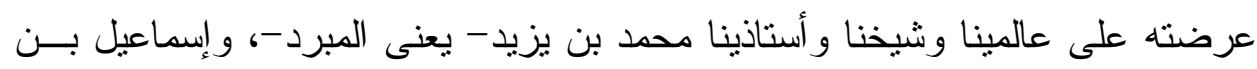

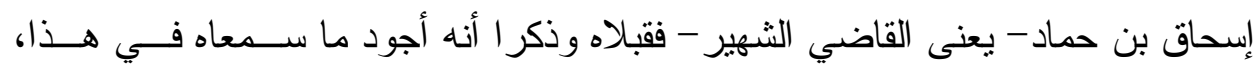

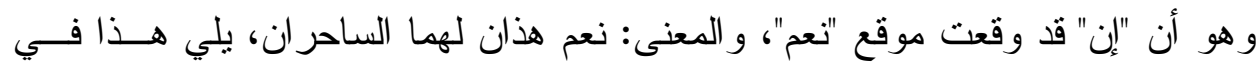

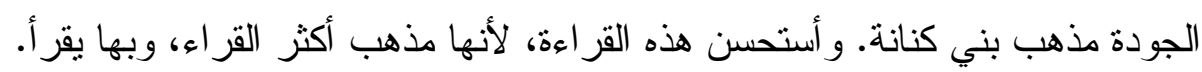

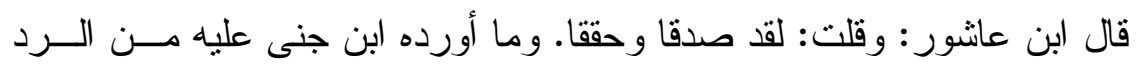

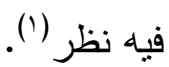

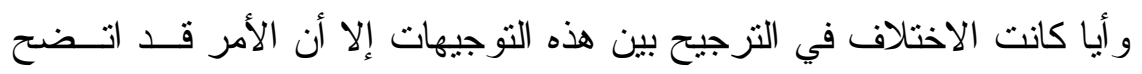

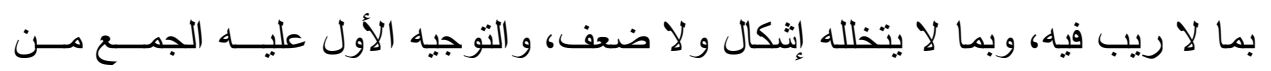
الأئمة.

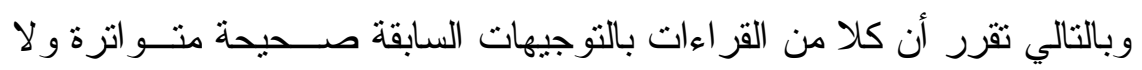

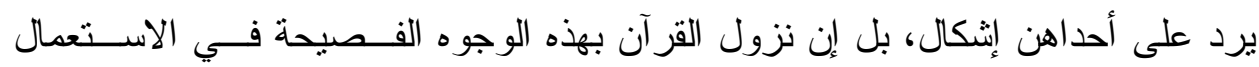

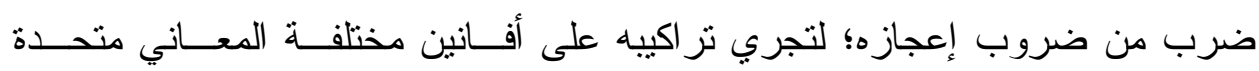

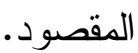

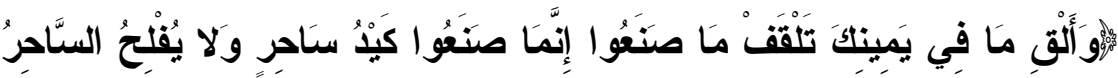

$$
\begin{aligned}
& \text { حَيْثُ َََُّٔى } \\
& \text { * اختلفت القراء في قوله: "كيا سحر". } \\
& \text { - فقر أ حمزة و الكسائي "كيد سحر" بغير ألف. فئ. } \\
& \text { - وقر أ الباقون "كيد ساحر" بالألف. } \\
& \text { * توجيه القراعتين: }
\end{aligned}
$$

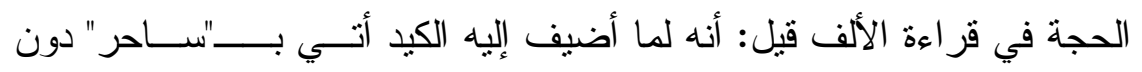

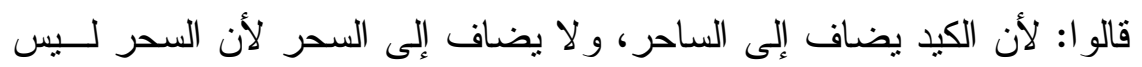

له كيد، و أنما الكيد للساحر يقوى هذا وقوله: "و لا يفلح الساحر حيث أني".

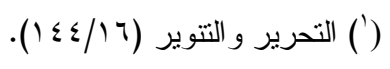




$$
\text { وحجة من قر أ بغير ألف: }
$$

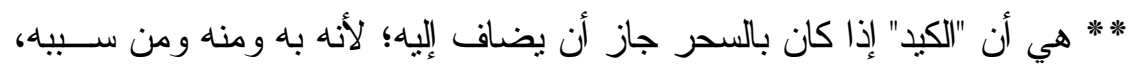

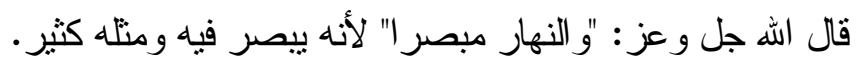

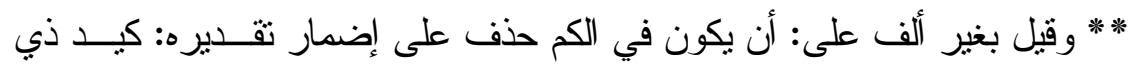

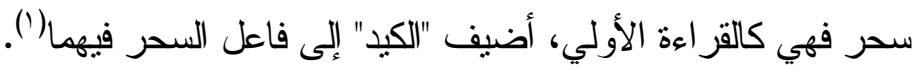

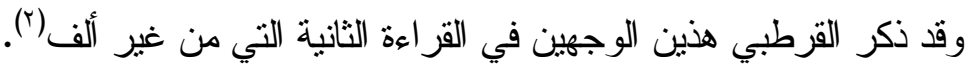

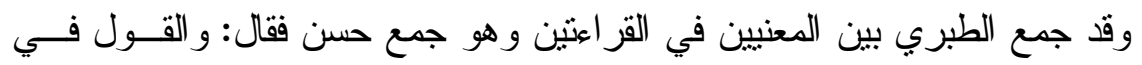

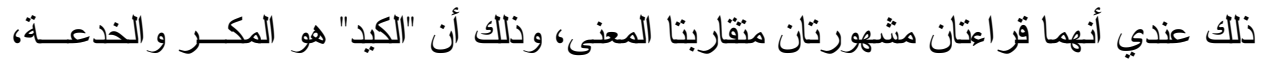

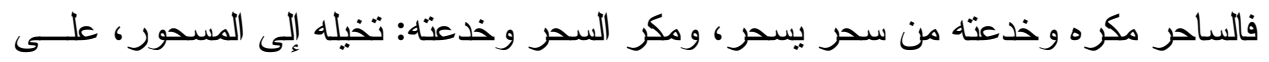

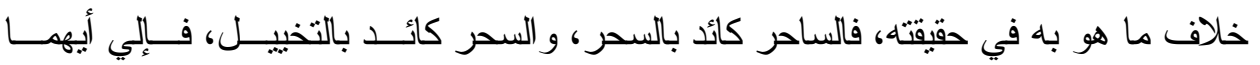

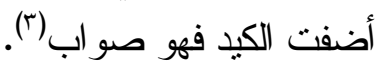

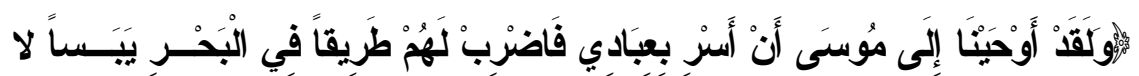

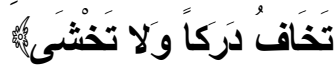
* اختافت القراء في قوله: "لأ تخف دركاً".

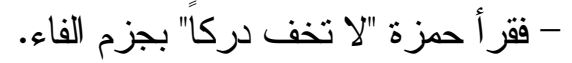
- وقر أ الباقون "لا تخزة "لاف دركاً" برفع الفاء. * توجيه القر اعتين:

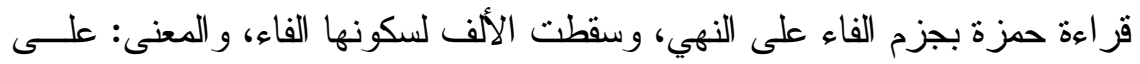

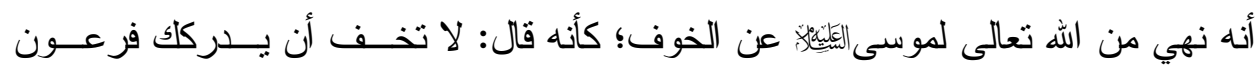

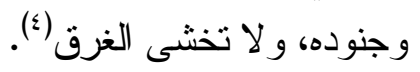

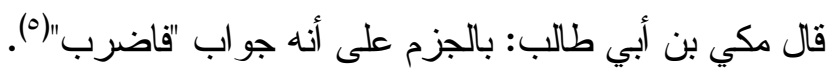

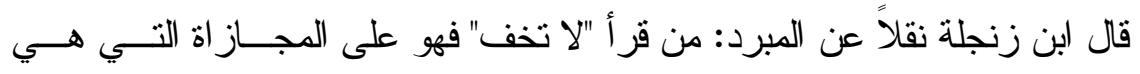

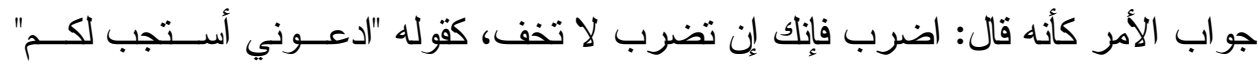

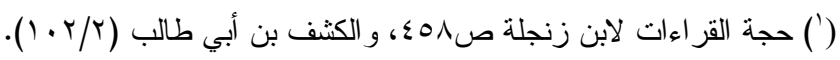

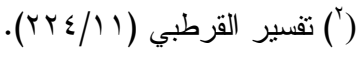

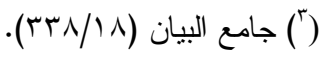

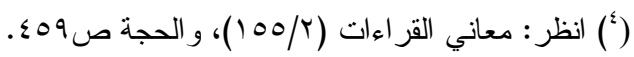

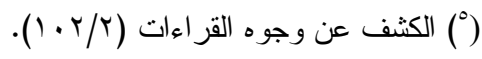


وقوله: "و لا تخشى" رفع على الاستئناف كما قال سبحانه: "يولوكم الأدبار ثــــ لا ينـــرون"

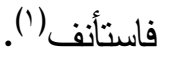

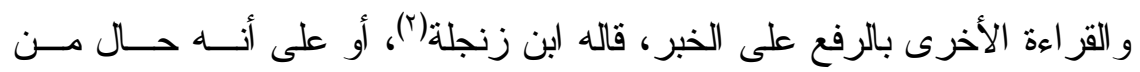

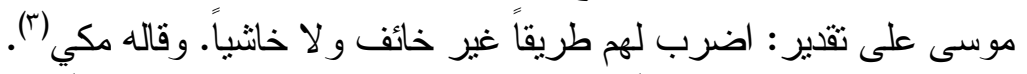

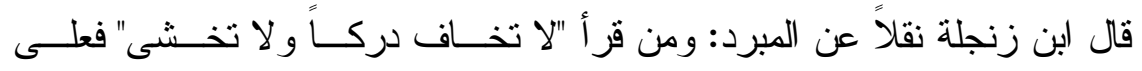

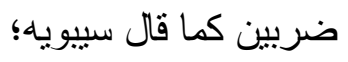

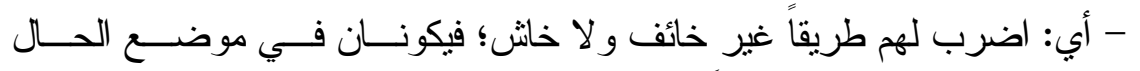

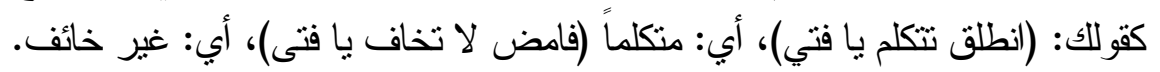

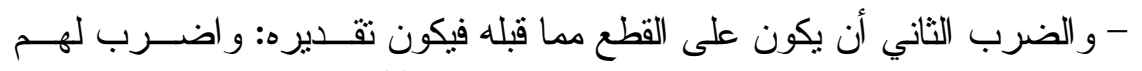

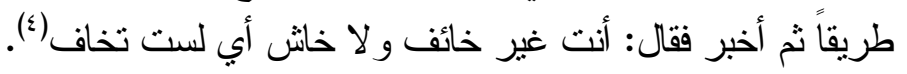

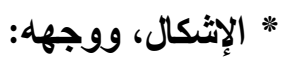
- الإنثكال: وردَ الإنشكال على قراءة حمزة- رحمه الله- "لا تخف دركــا" بجــزم الفاء وإسقاط الألف.

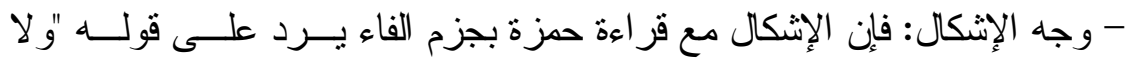

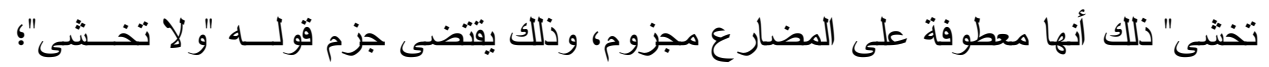

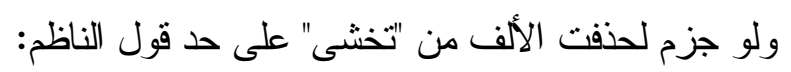

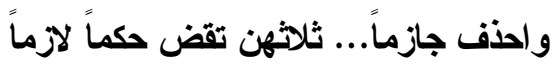

لكن الألف لم تحذف فوقع الإثكال بالسبب الدذكور آنفاً.

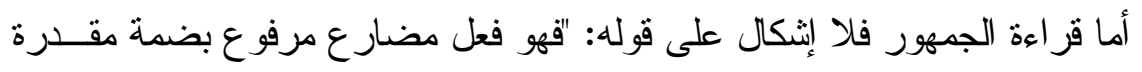

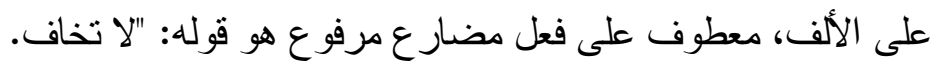

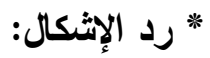

ويجاب عن الإثكال السابق من خال ثلاثة أوجه كالتالي:

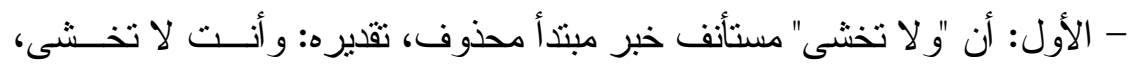
أي: ومن شنك أنك آمن لا تخشى. الأن

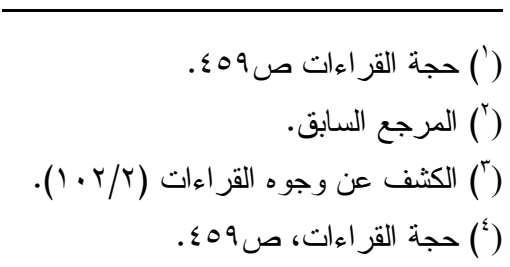




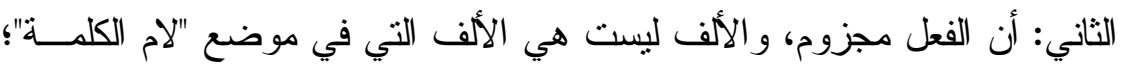

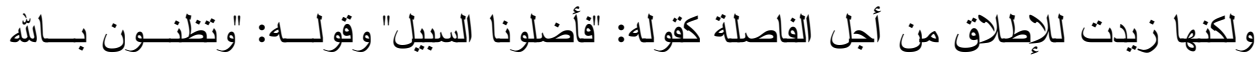
الظنون".

- الثالث: أن إثباع الحركة بحرف مد يناسبها أسلوب معروف من أساليب اللغـــة العربية، كقوله عبد يغوث بن وقاص الحارثي: وتضحك منى شيخة عبشمية... كأن لم تر قبلي أسيرًا يمانيا و الأصل هنا: كأن لم تز ، ولكن الفتحة أثنبعت.

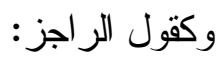

إذا العجوز غضبت فطلق... ولا ترضاها ولا تملق و الأصل هنا: و لا ترضها، ولكن الفتحة أثنبعت.

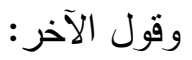

قلت وقد خرت على الكلكال... يا ناقتي ما جلت من مجال و الأصل هنا: على الكلكال يعنى الصدر ، ولكن الفتحة أثبعت. وقول عنترة في معلقته: ينباع من ذفري غضوب جسرة... زيافة مثل الفنيق المكلم و الأصل هنا: "ينبع" يعنى: أن العرق ينبع من عظم الذفري من ناقته على التحقيق، ولكن الفتحة أثنبعت.

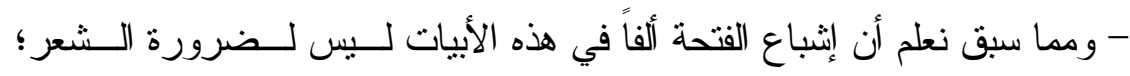

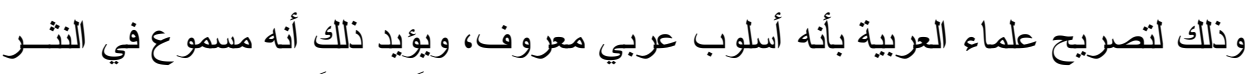
كقولهم في النثر : كلكال، وخاتام، وداناق، يعنون كلكلا، وخاتماً، ودانقاً.

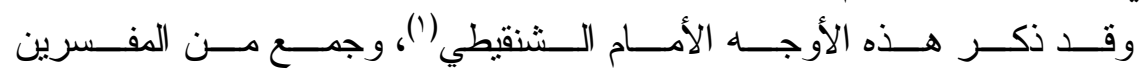

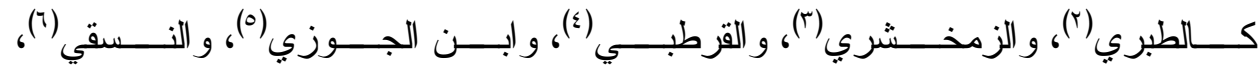

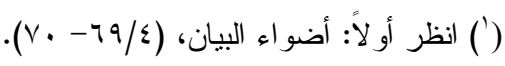

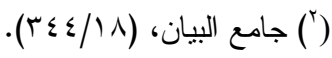

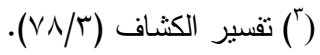

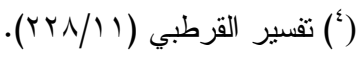

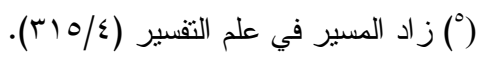

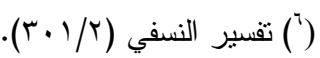




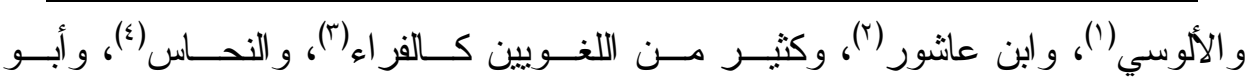

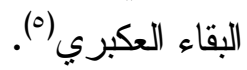

هذا وقد ذكر الفراء و الألوسي وجها آخر وهو : أن قولـــه: "لا تخـشى مجــزوم بحذف الحركة المقدرة.

قال الفراء: وإن شئت جعلت (تخشى) في موضع جزم وإن كانت فيها اليــاء؛ لأن

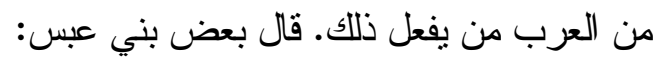

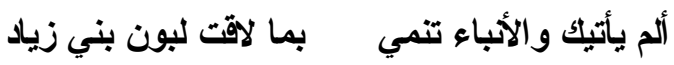

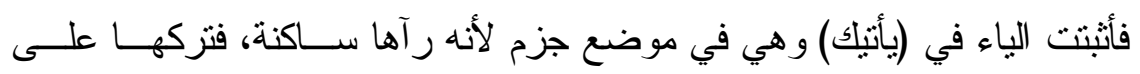

سكونها كما تفعل بسائر الحروف. فئن و أنشدني بعض بني حنيفة:

قال لها من تحتها وما استوي ل هزي إليك الجع يجنيك الجني

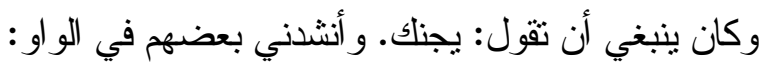

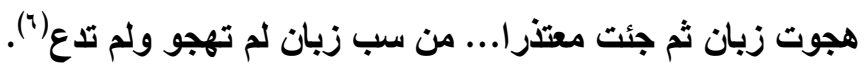

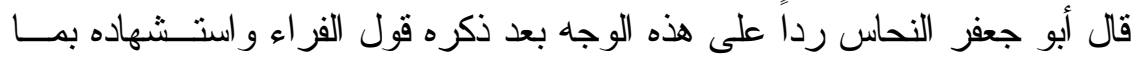

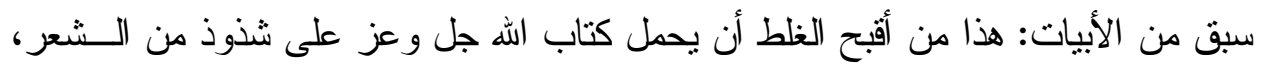

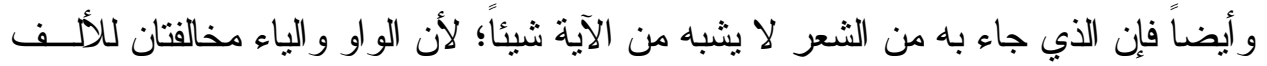

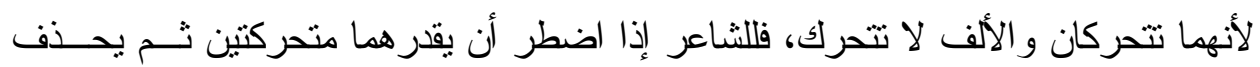

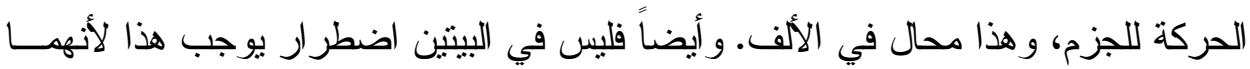

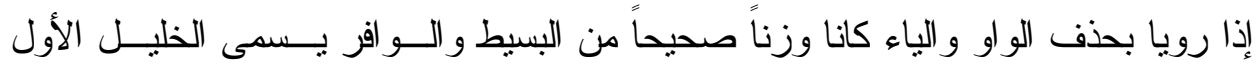
مطوياً و الثاني منقوصاً على معنى التعظيم و المعرفة بالأمر (v).

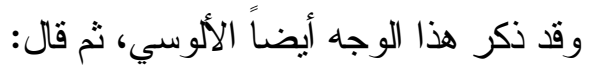

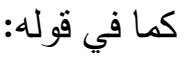

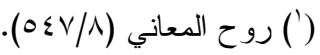

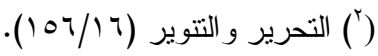

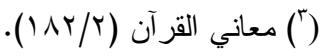

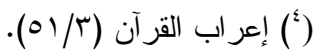

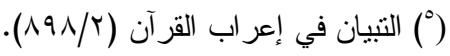

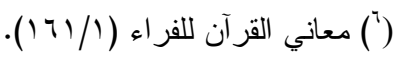

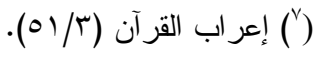




\section{إذا العجوز غضبت فطلق ولا ترضاها ولا تملق}

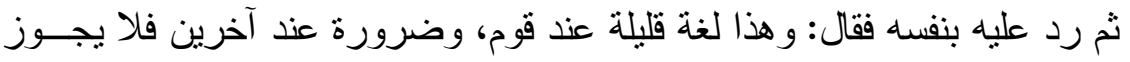

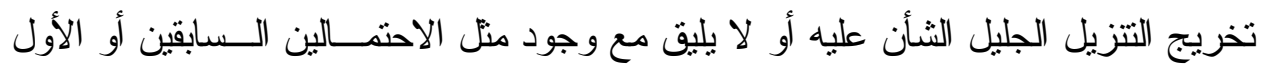
(') (1) (1)

قلت: ولعل فيما سبق من الأوجه الثلاثة السابقة ما يغني في الرد علــى الإشــكال

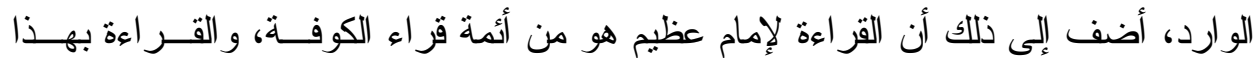

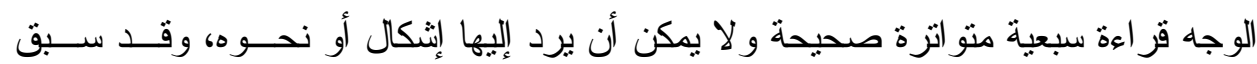

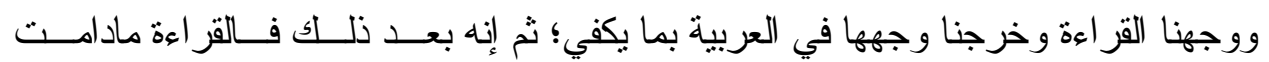
صحيحة متو اترة فإنها حجة على العربية وليس الأمر بالعكس، فافهم ذلك. وبالله التوفيق.

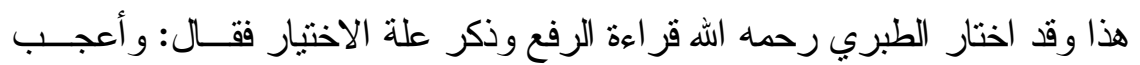

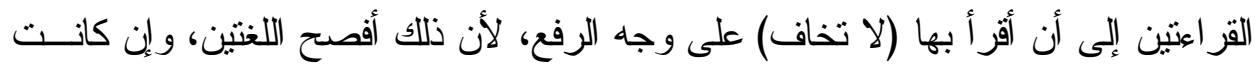

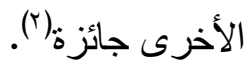

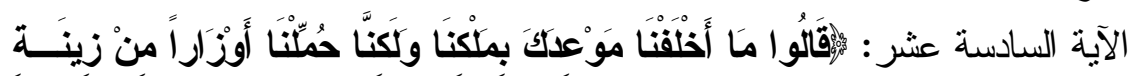

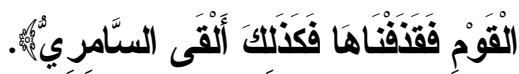

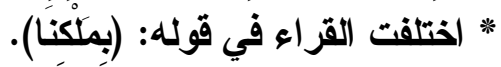
- فقر أ نافع و عاصم "'بملكنا" بفتح الميم. لمكئ. - وقر أ حمزة و الكسائي "بُملكنا" بضم الميم.

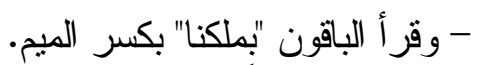
* توجيهات القراءات: الفتح والضم و الكسر كلها لغات، وهو مصدر إلاع أن: - (المُلك) بالضم مصدر من قولهم: هو ملك بين المُلك. - و (الملك) بالكسر مصدر من قولهم: هو مالكّ بين المكلك.

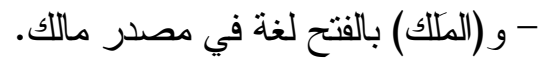
وهذا المصدر مضاف إلى الفاعل في جميع الوجوه وهو النون و الألف، و المفعـول ملفول محذوف وتقدير : ما أخلفنا مو عدك بملكنا، و الصو اب: إنما بخطيئنتا (َ).

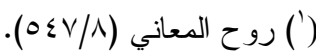

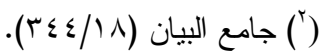

$$
\begin{aligned}
& \text { (") الكثف لمكي بن أبي طالب (r/ آع • ()). }
\end{aligned}
$$




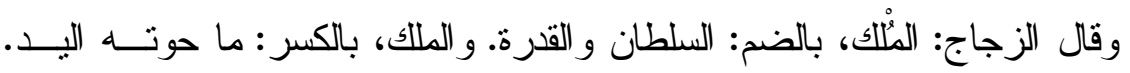

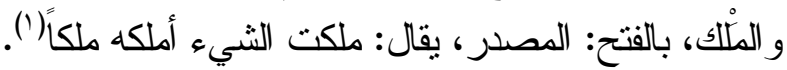
و اختلف المعنى بينها على ثلاث معان: - ما أخلفنا مو عدك بأمرنا. - وقال آخرون: معناه: بطاقتنا. - وقال آخرون: معناه: ما أخلفنا مو عدك بهو انا، ولكنا لم نملك أنفسنا.

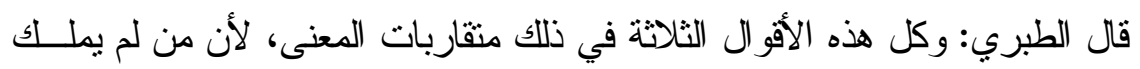

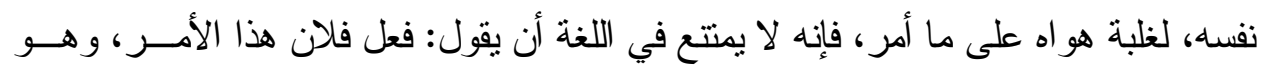

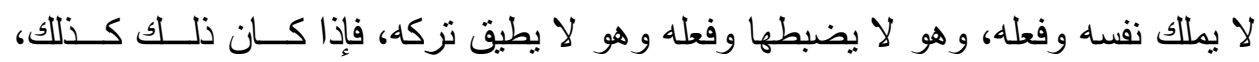

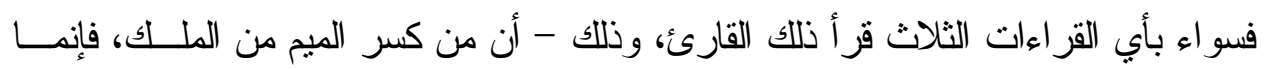

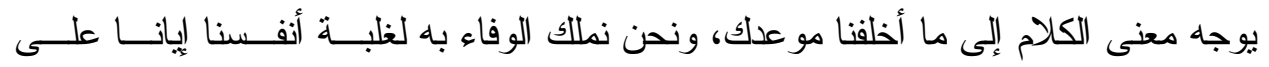

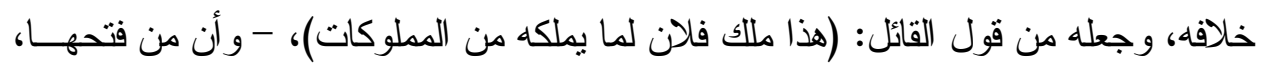

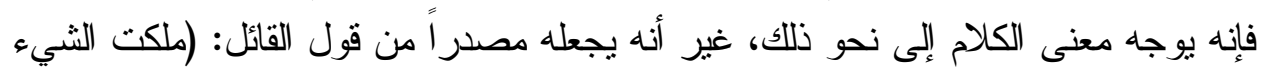

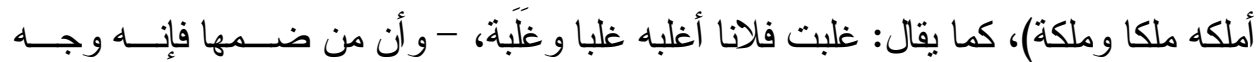

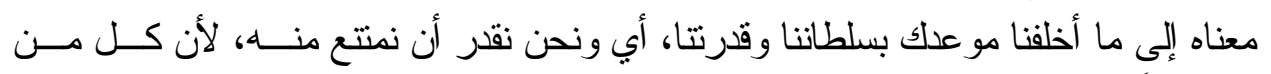
قهر شيئًا فقد صار له السلطان عليه.. (r).

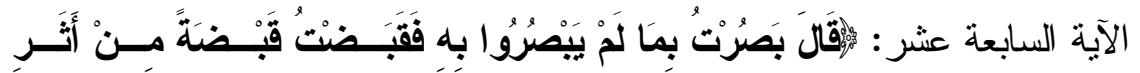

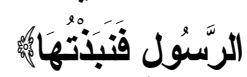

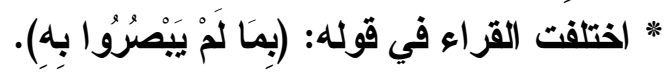

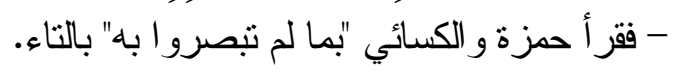

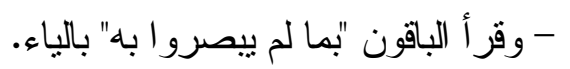
* توجيه القراعتين: ت وقرت

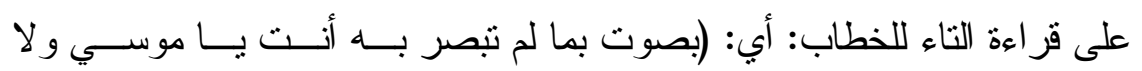

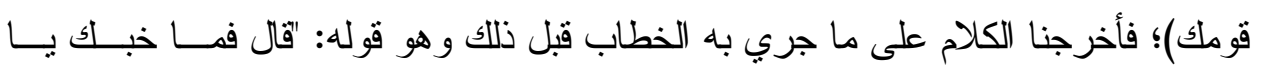

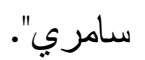

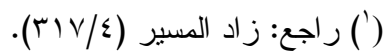

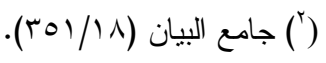




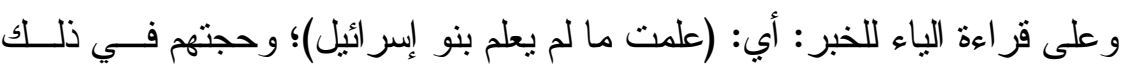

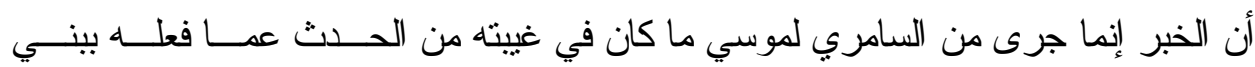

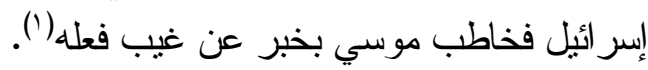

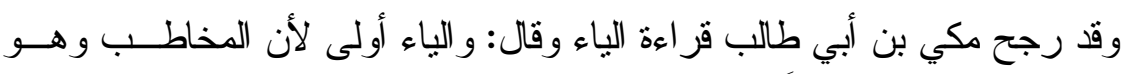

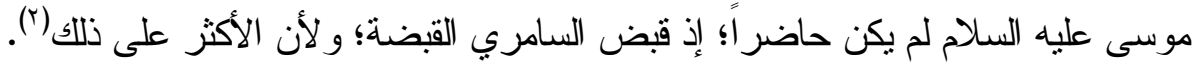

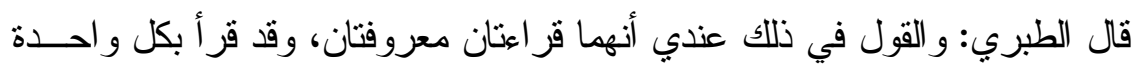

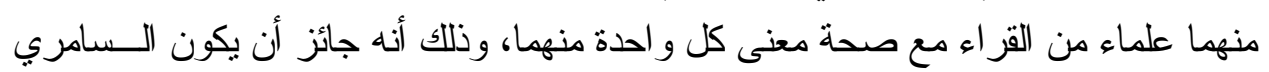

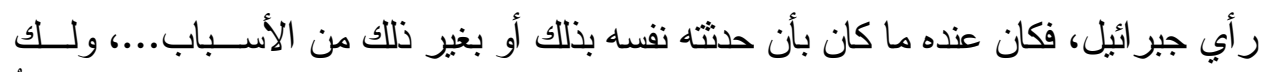

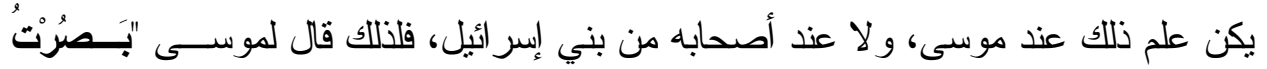

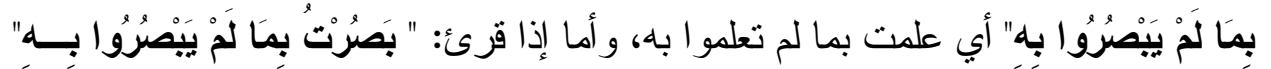

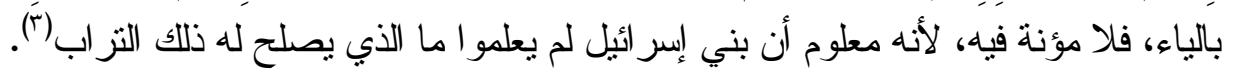

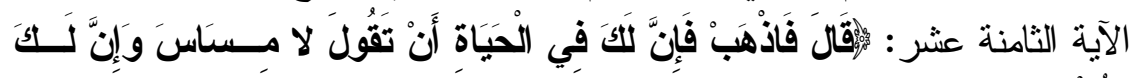

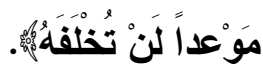

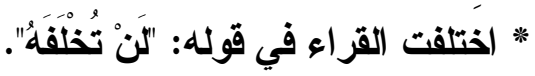

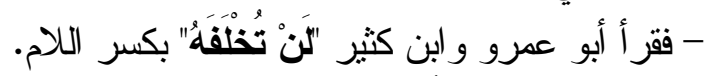

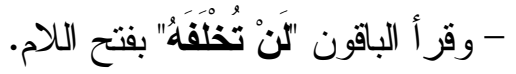
* توجيه القراعتين: ت وترن

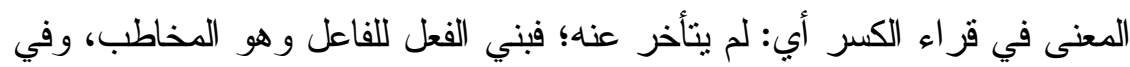

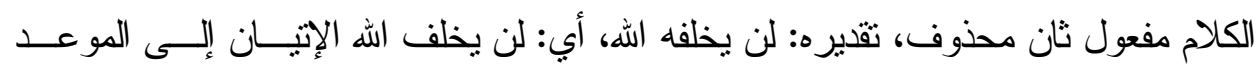
وهو الحشر يوم القيامة(؟). وقال النحاس: (و إن للك مو عدا لن تخلفه) بكسر اللام بحتمل معنيين:

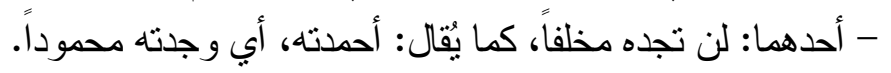

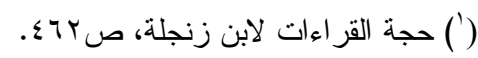

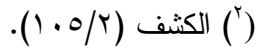

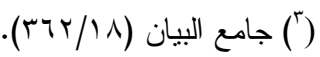

$$
\begin{aligned}
& \text { () () انظر : الكثّف عن وجوه القر اءات (ro/ . ()). }
\end{aligned}
$$


- و المعنى الآخر على التهيد أي: لابد للك من أن تصير إليه(').

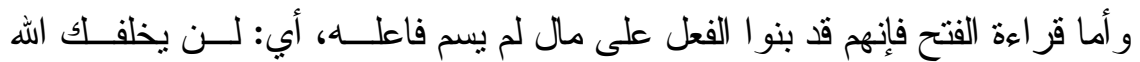
المو عد؛ بل يبعنك إليه من قبرك، و الفاعل هو الله تعالى أو موسى اليَلئهِ.

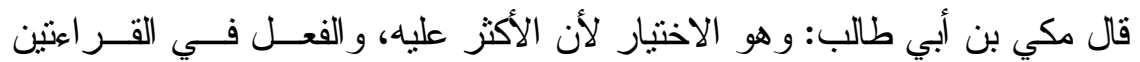

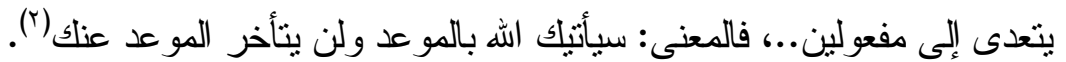

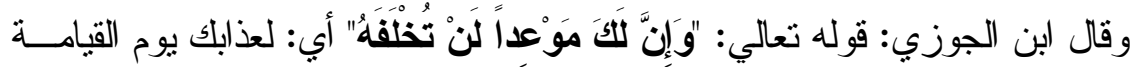

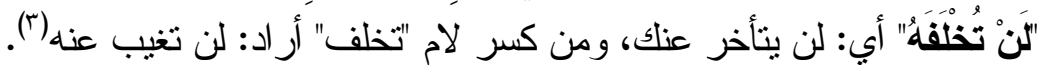

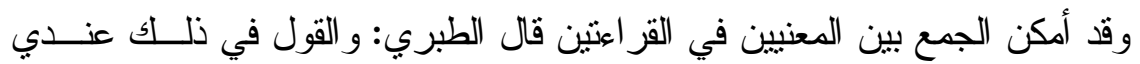

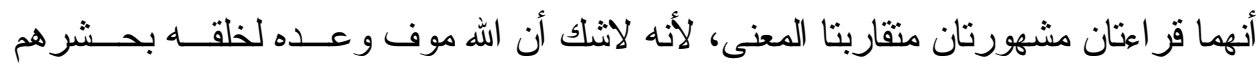

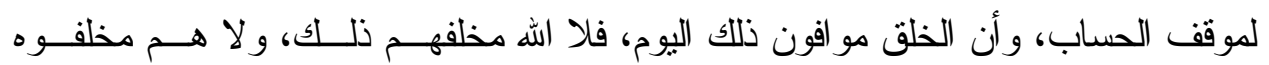

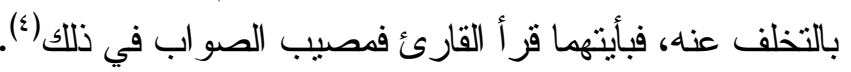

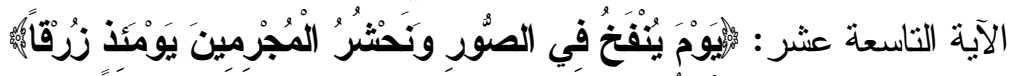
* اختلفت القراء في قُوله: " يُنْفَخُ".

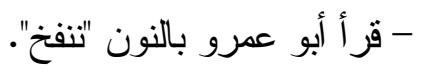
- وقر أ الباقون بالياء "يُنفخ".

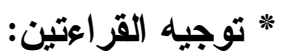
من قر أ بالنون: يكون المعنى أن الله تعالى أخبر عن نفسه علـــى أن يكــون آمــراً

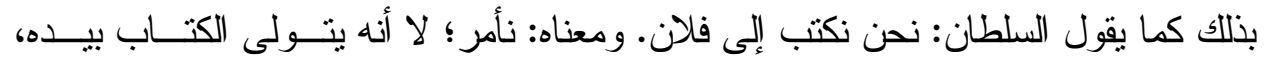

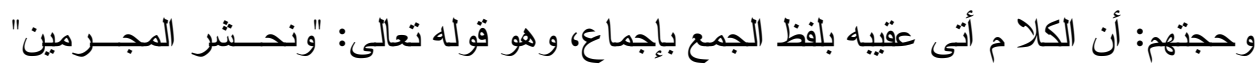

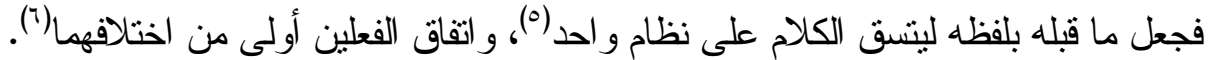

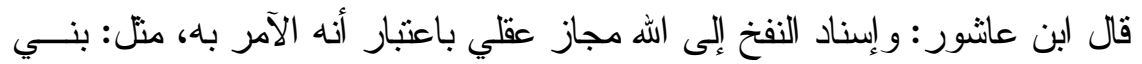

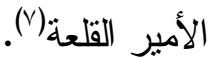

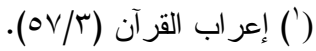

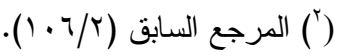

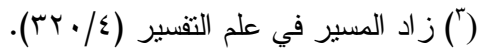

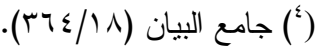

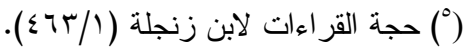

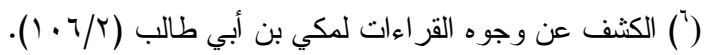

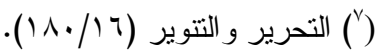




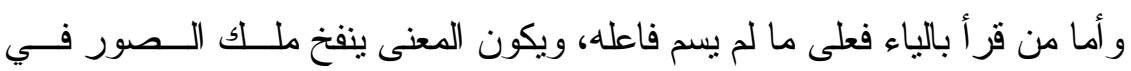

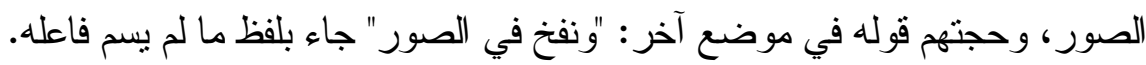

قال مكي بن أبي طالب: وهو الاختيار (').

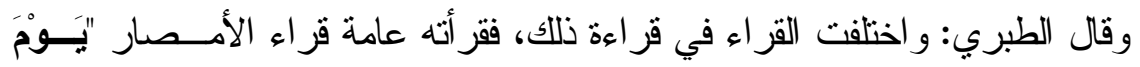

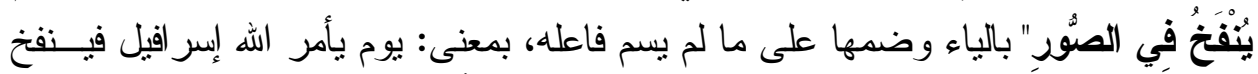

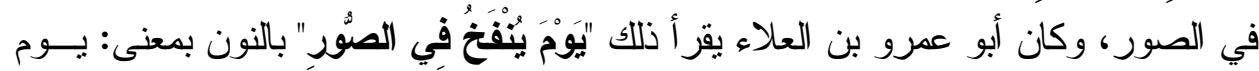

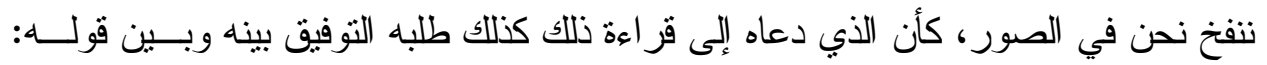

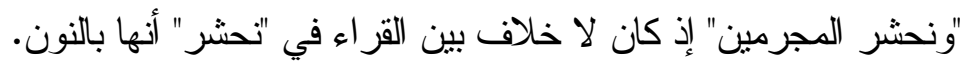

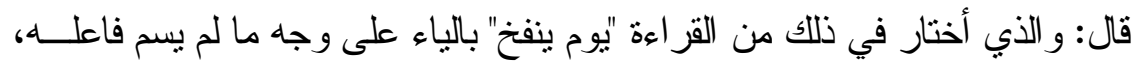

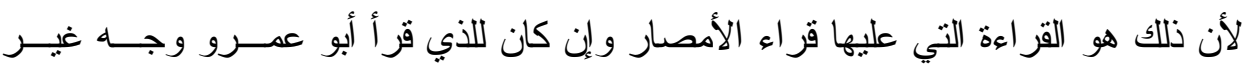

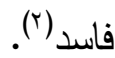

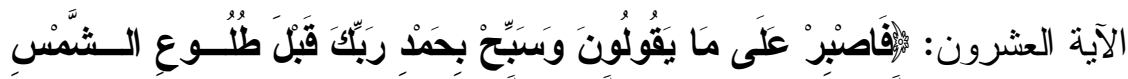

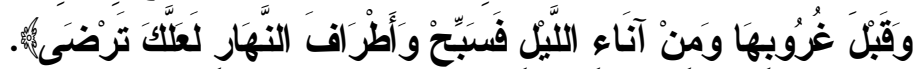

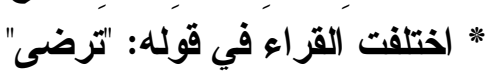
- فقر أ الكسائي و أبو بكر عن عاصم "رضع "لعلك ترضي" بضم التاء.

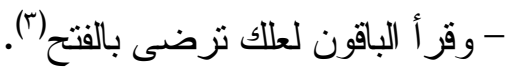

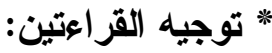

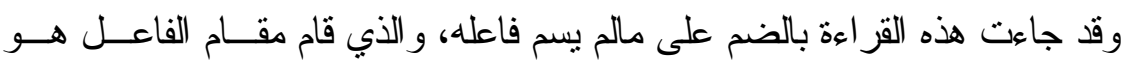
النبي من الهه واجبة.

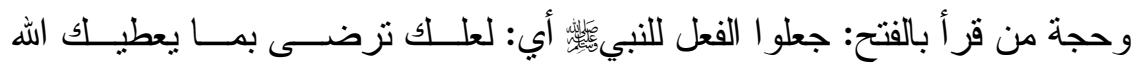

$$
\text { ودليله: "ولسوف يعطيك" (ई). }
$$

$$
\begin{aligned}
& \text { (') الكثف عن وجوه القر اءات (r/T • ()). }
\end{aligned}
$$

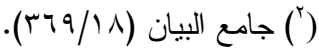

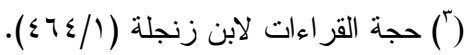

$$
\begin{aligned}
& \text { ( ) الكثف عن وجوه القز اءات (r/^ • (1). }
\end{aligned}
$$


قال مكي بن أبي طالب: وهو الاختيار لأن الأكثر عليه، فلابد أن يُعطي محمــدئ.

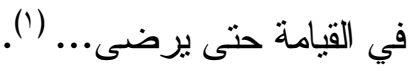

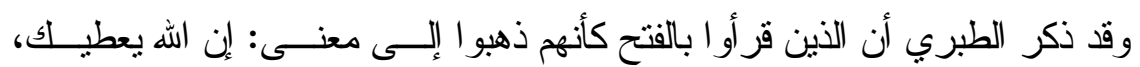

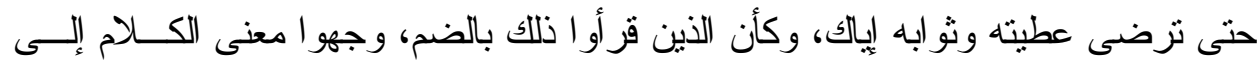

لعل اله برضيك من عبادنك إياه، وطاعتلك له (؟).

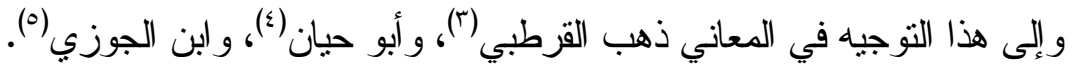

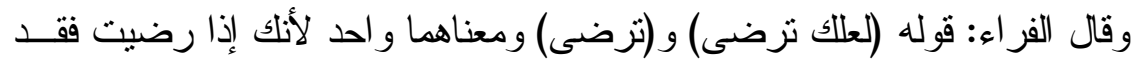

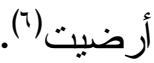

وقال أبو منصور الأزهري: المعنى فيهما واحد(").

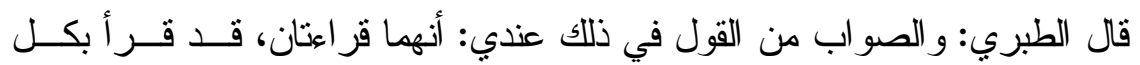

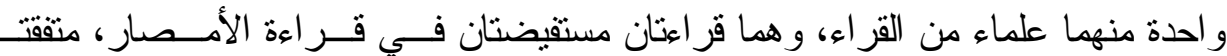

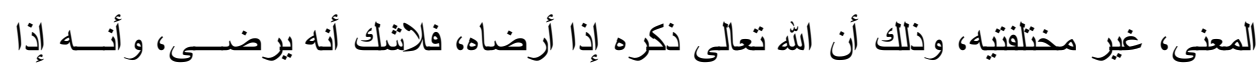

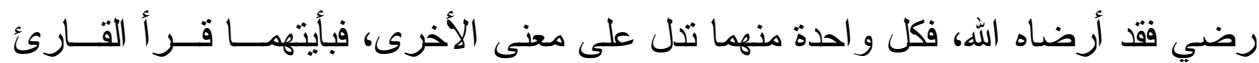

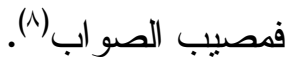

